HASI -246

\title{
$D R-2018$
}

$\frac{270}{1-6}$

This documeat is

PUBLICIY RELEASABLE

Authorizite Oricialy

Date:

tr. r.t.

\section{health and safety laboratory}

FALLOUT PROGRAM

QUARTERLY SUMMARY REPORT

January 1, 1972

\section{UNITED STATES ATOMIC ENERGY COMMISSION NEW YORK, N. Y. 10014}


This report was prepared as an account of work sponsored by the United States Government. Neither the United States nor the United States Atomic Energy Commission, nor any of their employees, nor any of their contractors, subcontractors, or their employees, makes any warranty, express or implied, or assumes any legal liability or responsibility for the accuracy. completeness or usefulness of any information, apparatus, product or process disclosed, or represents that its use would not infringe privately-owned rights.

\author{
Printed in the United States of America \\ Available from
}

National Technical Information Service

U. S. Department of Commerce

Springfield, Virginia 22151

Price: Printed Copy $\$ 3.00 ;$ Microfiche $\$ 0.65$ 


\section{DISCLAIMER}

This report was prepared as an account of work sponsored by an agency of the United States Government. Neither the United States Government nor any agency Thereof, nor any of their employees, makes any warranty, express or implied, or assumes any legal liability or responsibility for the accuracy, completeness, or usefulness of any information, apparatus, product, or process disclosed, or represents that its use would not infringe privately owned rights. Reference herein to any specific commercial product, process, or service by trade name, trademark, manufacturer, or otherwise does not necessarily constitute or imply its endorsement, recommendation, or favoring by the United States Government or any agency thereof. The views and opinions of authors expressed herein do not necessarily state or reflect those of the United States Government or any agency thereof. 


\section{DISCLAIMER}

Portions of this document may be illegible in electronic image products. Images are produced from the best available original document. 


\section{HEALTH AND SAFETY LABORATORY}

FALLOUT PROGRAM

QUARTERLY SUMMARY REPORT

(September 1, 1971 through December 1, 1971)

\section{Prepared by}

Edward P. Hardy, Jr.

Environmental Studies Division

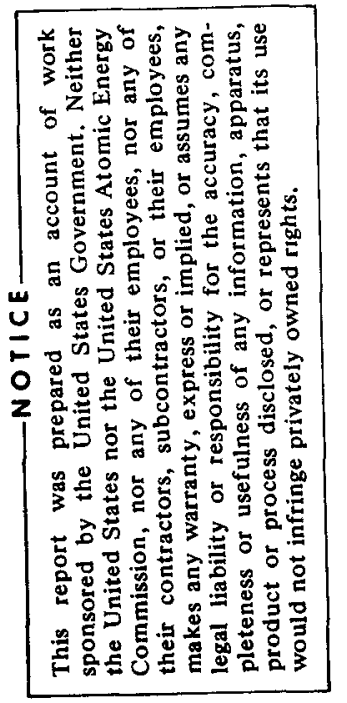

Preceding reports in this series:

Year

HASL Report NoS.

1958

1959

42,51

1960

65

1961

$77,84,88,95$

$105,111,113,115$

1962

$117,122,127,131$

1963

$132,135,138,140$

1964

$142,144,146,149$

1965

$155,158,161,164$

1966

1967

$165,171,172,173$

1968

$174,181,182,183$

1969

$184,193,197,200$

1970

$204,207,210,214$

1971

$217,224,227,237$

$239,242,243,245$

January 1, 1972

UNITED STATES ATOMIC ENERGY COMMISSION Health and Safety Laboratory

New York, N. Y. 
NYOO

HEALTH \& SAFETY

FALLOUT PROGRAM

QUARTERLY SUMMARY REPORT

January 1,1972

This report presents current data from the HASI Fallout Program, the Radiological Physics and Chemistry Divisions at Argonne National Laboratory, the Air Resources Laboratories of the National Oceanic and Atmospheric Administration, and the EURATOM Joint Nuclear Research Centre at Ispra, Italy。 The initial section consists of interpretive reports and notes covering the following topics: airborne Pu-239 at Rocky Flats, C-14 in the stratosphere, a high-volume air ejector sampler, stable lead in New York City diet, sr-90 in diet, and quality control analyses at HASL. Subsequent sections include tabulations of radionuclide levels in fallout, surface air, milk, and tap water. A bibliography of recent publications related to radionuclide studies, is also presented. 
Introduction

Part I - Interpretive Reports and Notes

Plutonium in the Neighborhood of Rocky Flats, I - 2 Colorado: Airborne Respirable Particles by H. L. Volchok, R. Knuth and M. T. Kleinmary Health and Safety Laboratory, USAEC

Analyses of Quality Control Samples at HASL and a Contractor Laboratory During 1971 by E. Hardy, Health and Safety Laboratory, USAEC

Stable Lead Concentrations in New York City Foodstuffs by D. C. Bogen, Health and Safety Laboratory, USAEC

Comparison of the Original and Modified HighVolume-3000 Air Ejector Samplers by T. E. Ashenfelter and K. Telegadas, Air Resources Laboratories, National Oceanic and Atmospheric Administration

Carbon-14 Measurements in the Stratosphere from a Balloon-Borne Molecular Sieve Sampier by K. Telegadas (1), J. Gray, Jr。 $\{2\}$ $R_{i}$ E. Sow ${ }^{(a)}$, and T. E. Ashenfelter $(i)$,

(i) Air Resources Laboratories, NOAA

(a) Argonne National Laboratory, Chemistry Divo

Estimation of Sr-90 Levels in the Diet by B. G. Bennett, Health and Safety Laboratory, USAEC

Part II - HASL Fallout Program Data

1. Fallout Deposition

1. 1 Monthly Precipitation

1. 11 Sr -90 and Sr-89 at World Lead

Sites

1.2 Sr-90 and Sr-89 at Atlantic Ocean Weather Stations 
Page

2. Radionuclides and Lead in Surface Air

Appendix C

3. Project Airstream

II -3

4. High Altitude Balloon Sampling

II -3

5. Radiostrontium in Milk and Tap Water

Appendix D

6. Strontium-90 in Diet

II -4

7. UNSCEAR - WHO Bone Program

II -3

B. Strontium-90 in Human Bone from New York

and San Franciso

II -3

Part III - Data from Sources other than HASL

1. EURATOM Joint Nuclear Research Centre, Ispra Bstablishment, Protection Service Site Survey and Meteorology Section Quarterly Report

2. Radiological Physics Division, Argonne III - 7 National Laboratory, Cesium-137 in Various Chicago Foods (Collection Month, October 1971)

by S. S. Brar and D. M. Nelson

3. Global Atmospheric Radioactivity: January III - 11 1970

Part IV - Recent Publications Related to Radionuclide Studies

\section{Appendix}

A. Sr-90 and Sr-89 in Monthly Deposition at A - 1 World Iand sites

B. Radiostrontiun Deposition at Altantic Ocean B - 1 Weather Stations

C. Radionuclides and Lead in Surface Air C - 1

D. Radiostrontium in Milk and Tap Water D - 1

B. Table of Conversion Factors E - 1

F. Table of Radionuclides F - 1 
$\underline{\text { Table }}$

$\underline{\text { Page }}$

Fallout Deposition

1.a. Sr-90 and Sr-89 in Monthly Deposition at World Land Sites

Appendix $A-4$ thru A-

b. Radiostrontium Deposition at Atlantic Ocean Stations

BRAVO
CHARLIE
DELTA
ECHO

Surface Air

2.a. HASL Surface Air Sampling Stations

b. Gross Gamma Concentrations in Surface Air

c. Beryllium-7

d. Manganese-54

e. Iron-55

f. Strontium-89

g. Strontium-90

h. Zirconium-95

i. Cadmium-109

j. Cesium-137

k. Cesium-141

1. Cerium-144

m. PIutonium-238

n. Plutonium-239

o. Stable Lead

\begin{tabular}{|c|c|c|c|}
\hline " & " & "I & " \\
\hline 11 & 11 & 11 & "I \\
\hline " & " & 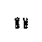 & " \\
\hline " & 11 & 18 & 11 \\
\hline " & "I & "1 & "I \\
\hline 18 & 98 & 8 & 18 \\
\hline$"$ & is & $\mathrm{HI}$ & 18 \\
\hline II & 80 & 18 & 11 \\
\hline "I & 18 & 1 & Be \\
\hline " & 11 & 18 & Iy \\
\hline 11 & "1 & $\|$ & $\mathrm{PH}$ \\
\hline$"$ & " & 18 & II \\
\hline 11 & 11 & 11 & $r$ \\
\hline
\end{tabular}

Appendix 68

$\mathrm{C}=1$ ?

$C-19$

$\mathrm{C}-2 \mathrm{I}$

C -25

$\mathrm{C}=31$

$C-4$

C. 4,

$c-58$

C 62

$(-75$

$\mathrm{C}-7 \mathrm{~A}$

C .83

$c-9:$

C -97

\section{Milk and Tap Water}

5.a. The Sr-90 to Ca Ratio in New York City Liq- Appendix D-3 uid Milk

b. The Sr-90 to Ca Ratio in Perry, N. Y. $\mathrm{D} \rightarrow 4$ Powdered Milk 


\section{List of Tables - cont'd}

c. Sr-90 in New York City Tap Water

d. The Cs-137 to Sr-90 Ratio in New York City Tap Water

Diet

6. Sr-90 in New York City and San Francisco Diets Second Quarter 1971

\section{Page}

Appendix D-6

$D=7$

$I I-5$ 


\section{List of Figures \\ Part II \\ HASL Fallout Program}

Figure

Page

Fallout Deposition

1.a. HASL Monthly Fallout Sampling Network

b. Monthly Deposition of $\mathrm{Sr}-90$ in New York City

Milk and Tap Water

5. a. Sr-90 in Powdered Whole Milk - Perry, N. $\mathrm{Y}$.

b. Sr-90 in Liquid Whole Milk - New York City

$\mathrm{D}-5$

c. Sr-90 in New York City Tap Water

$D-8$

Diets

6. Daily Intakes of $\mathrm{Sr}-90$

II -6 
Every three months, the Health and Safety Laboratory issues a report summarizing current information obtained at HASL pertaining to fallout. This report, the latest in the series, contains information that became available during the period from September 1, 1971 to December 1, 1971. The next report is scheduled for publication April 1, 1972. Preceding reports in the series, starting with HASL-42, "Environmental Contamination from Weapons Tests", and continuing through HAsL-246, (this report) may be purchased from the clearinghouse for Federal Scientific and Technical Information, National Bureau of Standards, U. S. Department of Commerce, Springfield, Virginia 22151. A complete listing of these Fallout Program Quarterly Summary Reports is given on the title page of this report.

To give a more complete picture of the current fallout situation and to provide a medium for rapid publication of radionuclide and trace element data, these quarterly reports often contain information from other laboratories and programs, some of which are not part of the general AEC program. To assist in developing, as rapidly as possible, provisional interpretations of the data, special interpretive reports and notes prepared by scientists working in the field of fallout are also included from time to time. Many of these scientists are associated in some way with the general AEC program. Information developed outside of HASL is identified as such and is gratefully acknowledged by the Laboratory. In this report, data from the EURATOM Joint Nuclear Research Centre at Ispra, Italy, the Divisions of Radiological Physics and Chemistry at Argonne National Laboratory, and the Air Resources Laboratories of the National Oceanic and Atmospheric Administration, are given.

A portion of the radiochemical analyses either have been or are being carried out by commercial laboratories under contract to the HASL Environmental studies Division. The results of these analyses are reported as part of HASL's regular fallout program. The contractor analytical laboratories which provided data are Nuclear Science and Engineering Corporation, Pittsburgh, Pa.; Isotopes, Inc., Westwood, N.J.; Radiochemistry Incorporated, Louisville, KY; Tracerlab, Div. of LFE, Richmond, Calif. (now Trapelo Div./West); Controls for Radiation, Inc., Cambridge, Mass; Hazleton-Nuclear Science Corp., Palo Alto, Calif. (now Isotopes Palo Alto Laboratories); Food, Chemical and Research Laboratories, Inc., Seattle, Washington; Custom Nuclear Co., Mountainview, Calif., Ledoux and Company, Teaneck, N. J., and U. S. Testing Co., Richland, Washington.

This report is divided into four main parts:

1. Interpretive Reports and Notes

2. HASL Fallout Program Data

3. Data from Sources Other than HASL

4. Recent Publications Related to Radionuclide Studies 
PART I

INTERPRETIVE REPORTS

and

$\mathrm{N} O \mathrm{~T} E \mathrm{~S}$ 
X PLUTONIUM IN THE NEIGHBORHOOD OF ROCKY FIATS, COLORADO: AIRBORNE RESPIRABLE PARTICLES

\author{
by H. L. Volchok, (HASL) \\ R. Knuth, (HASL) \\ M. T. Kleinman, (HASL)
}

\begin{abstract}
Several experiments were carried out, offsite, but close to the Rocky Flats plutonium plant, to determine the respirable fraction of the resuspended $\mathrm{Pu}^{00}$. The results indicate that in this area, with concentrations in excess of $1 \mathrm{fCi} / \mathrm{m}^{3}$, the respirable fraction is abou $t \quad 0.2$ to 0.4 . These experiments also provided evidence that the main source of the resuspended $\mathrm{Pu}^{\mathrm{B} 9}$ is probably located somewhat east of the plant site, and that very steep vertical gradients of $\mathrm{Pu}$ concentrations may be present in the air in this vicinity.
\end{abstract}

Introduction and Background

The Rocky Flats plant, operated by the Dow Chemical company for the Atomic Energy Commission, produces plutonium parts for nuclear weapons. It is located about 20 miles northwest of Denver and 12 miles south of Boulder, Colorado. A number of other towns of 2,000 or more population are within 8 to 10 miles to the north, east and south. 
National interest in the environmental situation with regard to plutonium, in the area near the Rocky Flats plant, was aroused in early 1970. Dr. Edward Martell, at that time representing the Colorado Committee for Environmental Information (CCEI), demonstrated the presence of excess plutonium in soil near the plant (1). The CCEI investigation, spurred by a serious fire at the plant in May of 1969, suggested among otrex things, that curies to tens of curies of plutonium from the plant had been deposited in offsite areas, and that "...the continuation of plant operations at this site represents a serious threat to the health and safety of the people of the Denver area."

The Health and Safety laboratory (HASL) conducted a study of the distribution of $\mathrm{Pu}^{\mathrm{a}} \mathrm{s}$ in the offsite neighborhood of the plant, in February 1970. This study has been completed and published, (2). The major findings were:

(a) The most likely source of the offsite plutonium contamination was barrels of contaminated cutting oil. stored on the southeast corner of the plant property, and known to have leaked. 
(b) The upper limit of the inventory of $\mathrm{Pu}^{33}$ on non government property, which could be attributed to contamination from the Rocky flats plant was 5.8 curies .

(c) The pattern of contamination on the ground is generally compatible with the average wind vectors for the area. This, along with the low precipitation and high winds, suggests that the major mechanism of transport of the plutonium from the drum storage area, was resuspension.

In line with this last conclusion, and reflecting the understanding that inhalation (in contrast to ingestion) is probably the more effective mode of entry of plutonium into critical organs (3,4), HASL, in mid 1970, set up air sampling equipment at the east boundary fence of the plant. This point is adjacent to the barrel storage area. Our motive was to systematically document the $\mathrm{Pu}^{239}$ concentration in the air in the area of highest ground concentration. The results (5) indicate that the $\mathrm{Pu}^{2} 3 \mathrm{~g}$ levels, while quite variable, generally correlated with wind velocities of over 8 miles per hour. The monthly concentrations 
averaged over ten times those expected from fallout, and varied between 1 and 10\% of the most conservative maximum permissible concentration (mpc), which is $60 \mathrm{fCi} / \mathrm{m}^{3}$ for soluble $\mathrm{Pu}$ with bone as the critical organ.

This report describes our most recent experiments at Rocky Flats, attempting to characterize the size of the plutonium bearing particles in the aerosol. This information bears directly on the facility for these particles to penetrate the respiratory tract and lungs, and therefore may be used to evaluate the radiation risk. The usual ways of estimating the hazard due to insoluble particles depend upon a knowledge of that portion of the inhaled dust which is deposited in the non-ciliated part of the lung. This is termed the "respirable" fraction $(6,7,8)$ 。

The British Medical Research Council (BMRC) defined the characteristics of the respirable fraction of inhaled dust in terms of the aerodynamic diameter (AD) of the particles (7). Hence, all particles of diameter less than 1.5 microns ( $\mu$ m) are respirable。 while only $50 \%$ of the $5.0 \mu \mathrm{m}$ and none larger than 7.1 um are deposited.

At a conference at the Los Alamos Scientific Laboratory (IASL) in 1961, a slightly different set of particle sizes were 
developed, to define the respirable fraction (6). In this, the deposited percentages are: $100 \%$ below $2 \mu \mathrm{m}, 50 \%$ of $3.5 \mu \mathrm{m}$ and $0 \%$ over $10 \mu \mathrm{m}$.

A simple mathematical relationship between the two lung retention models has been developed $(9,10,11)$ as follows:

$$
F R_{L A S L}=0.8\left(F R_{B M R C}\right) \pm 0.1 \quad\left(F R_{B M R C}\right)
$$

In this $F_{L A S L}=$ the fraction respirable by the LASL model。 $\mathrm{FR}_{\mathrm{BMRC}}=$ the fraction respirable by the BMRC model.

Hence, the BMRC assumptions will result in slightly higher respirable fractions than the LASL。

The only information directly pertaining to this specific problem at Rocky Flats was developed in a study of particles on the HASL filter papers (12). In this the Puas was found on "rost" particles with a mean diameter of about $10 \mu \mathrm{m}$. From the particle size distribution presented, and assuming a density of 2.5 for the particles, the respirable fractions were calculated to be between .05 and .07. 
Sampling and Analysis

The sampling was carried out during the period October $12-14$. 1971 near Rocky Flats. Our primary goal was to assess the respirable fraction of the airborne $\mathrm{Pu}^{39}$ in terms of both the BMRC and LASL models. The BMRC definition can be approximated by use of a horizontal elutriator followed by a high efficiency filter $(13,14,15)$. The elutriator used in these tests is $20 \mathrm{~cm}$. wide, $50 \mathrm{~cm}$. Iong with 19 channels spaced at $0.124 \mathrm{~cm}$. It was operated at a flow rate of 6.25 cubic feet per minute $\quad=0.175 \mathrm{~m}^{3}$ per minute) to give $100 \%$ removal efficiency for $7.1 \mu \mathrm{m}$ particles as specified in the BMRC model. The respirable fraction passing through the elutriator was filtered on Microsorban, a highly efficient polystyrene material.

The LASL model can also be approximated by a two stage sampler consisting of a cyclone and filter $(6,16)$. We used an instrument essentially described in reference (6); a one inch diameter cyclone first stage operated at a flow rate of 3.5 cubic feet per minute $\left(=0.098 \mathrm{~m}^{3}\right.$ per minute) backed again by a Microsorban filter for the respirable fraction.

The immediate neighborhood of Rocky flats with the locations of the four sampling sites, is shown in Fig. 1 . The east-southeast 


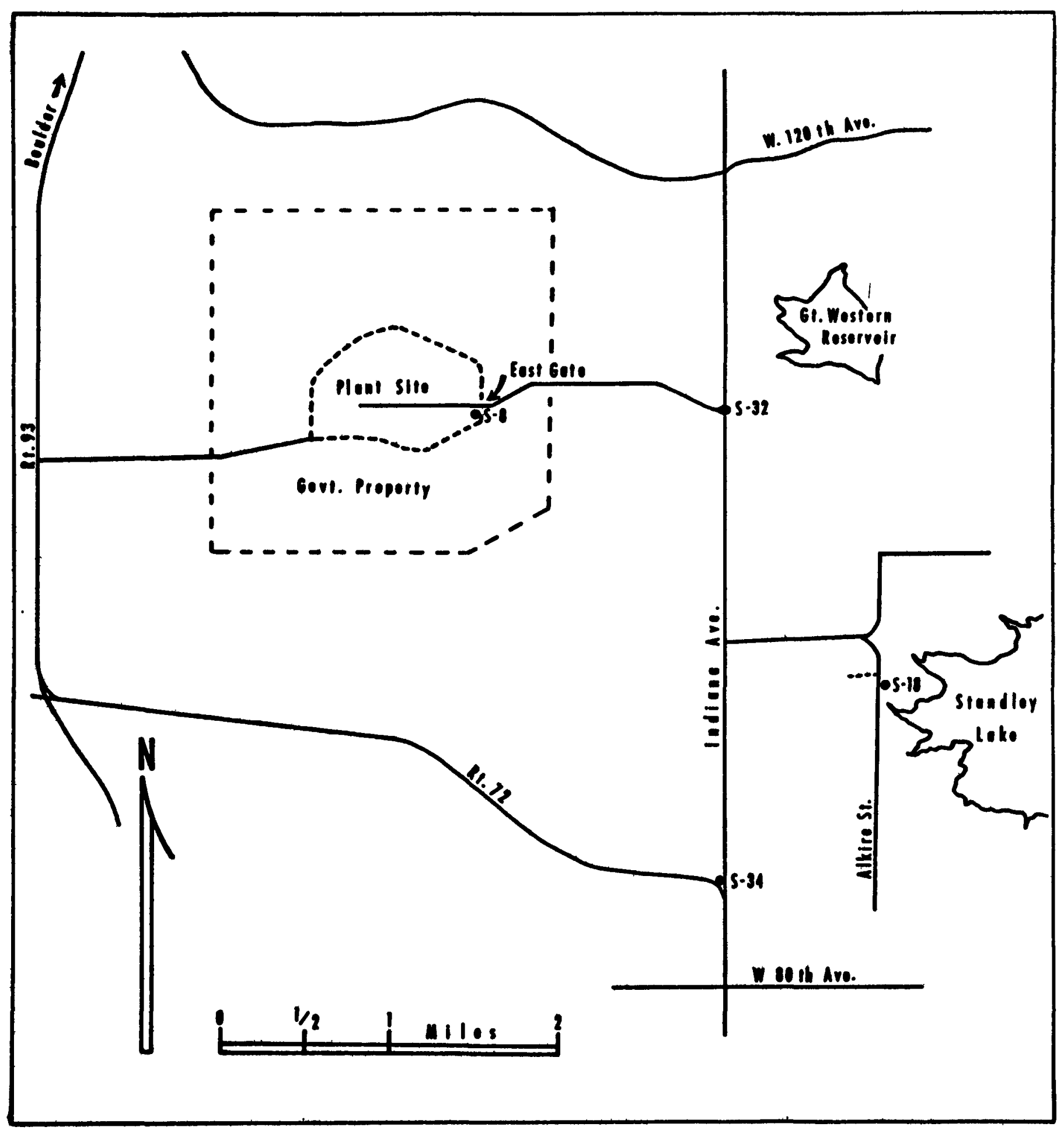

Fig. 1 - The Environs of Rocky Flats Plant, Colorado 
sampling pattern was chosen because of the prevailing wind patterns and the observed distribution of $\mathrm{Pu}^{39}$ in the soil (2). The "S" numbers designating the stations are those used by Dow in their environmental surveillance reports (e.g., 17)。 s-8 is just inside of the east security fence, very close to the point of continuous air sampling mentioned above (5). This site is considered most important and was therefore most heavily instrumented. The elutriator (only one was available) and two cyclone sets were all run continuously for about 54 hours at s-8. In addition, two hi-vol Staplex samplers, with Microsorban filters were run for the same period as a control, to measure the total Pu'39 air concentration. All of the samplers at this site were operated at about 3 feet above the ground.

At the other three sites conditions were much less ideal due to power shortage and a number of compromises had to be made. At s-32 and s-34 we could only run one cyclone for the entire period and one staplex for about $70 \%$ of the time. Further, the cyclones were located at about $3 \mathrm{ft}$. above the ground while the staplex was at about $7.5 \mathrm{ft}$. At site 18, the electrical power was even more restricted, and only one cyclone could be operated. 
The winds were quite variable through most of the sampling period. During the first day they were mainly from the north and northwest, and averaged about 6 miles per hour (mph), with gusts up to $33 \mathrm{mph}$. The second day had mostly southerly and "variable" winds reported, again averaging 6 and gusting to $21 \mathrm{mph}$. On the third day we experienced the prevailing wind patterns, mostly NW, W and SW. These winds averaged $11 \mathrm{mph}$ and there was a westerly gust of $43 \mathrm{mph}$.

The plutonium analyses were carried out by both HASL and Trapelo/ West. Both laboratories received "blind" knowns and blanks for evaluation of the quality of the analyses. In all cases the blanks were less than $0.01 \mathrm{dpm} \mathrm{Pu}^{39}$ and the knowns were reported to closer than $10 \%$ of the true value.

\section{Results and Discussion}

Table 1 lists the results from the four sampling sites near the Rocky fiats plant. The samples from site-8, near the east gate of the plant, are very consistent with respect to both total Pusa concentration and the respirable fraction. The mean concentration for the total 54 hour sampling period, based upon 4 data (two staplex and two cyclone sets) was $6.25 \pm 0.35 \mathrm{fCi} / \mathrm{m}^{3}$ 。 The average 
Table 1

PU239 CONCENTRATIONS IN ROCKY FLATS PARTICLE SAMPLING EXPERIMENT

Site

Sample

Volume $\left(\mathrm{m}^{3}\right)$

$\underline{\mathrm{Pu}_{39}\left(\mathrm{fCi} / \mathrm{m}^{3}\right) *}$

Fraction

Respirable

$s-8$

Elutriator Filter

566

1.82

$0.29 * *$

Cyclone-6

318

4.55

Cyclone-6 Filter

318

0.80

0.15

Cyclone-4

316

5.19

Cyclone-4 Filter

316

1.42

0.21

$\begin{array}{lll}\text { Staplex-A } & 4097 & 6.64 \\ \text { Staplex-B } & 4226 & 6.38\end{array}$

s-32

Cyclone-1

316

12.34

Cyclone-1 Filter

316

6.58

0.35

Staplex-C

2957

5.80

$s-18$

Cyclone-2

295

$0.10(\mathrm{~A})$

Cyclone-2 Filter

295

0.07 (A)

$s-34$

Cyclone-3

313

1.38

Cyclone-3 Filter

313

$0.12(\mathrm{~A})$

$0.08(\mathrm{~A})$

Staplex-D

4256

$0.03(\mathrm{~A})$

* $1 \sigma$ errors are less than $\pm 10 \%$ unless noted by.

f) for errors of $\pm 50 \%$ or greater.

* calculated by use of average total concentration $=6.25 \pm 0.35 \mathrm{fCi} / \mathrm{m}^{3}$.

$$
I-11
$$


respirable fraction from the two cyclone experiments was 0.18 . Using the relationship described earlier, between the BMRC and LASL models, and based on the cyclone result, we would expect the elutriator experiment to have indicated a respirable fraction of $0.23 \pm .03$. In fact the elutriator filter, when compared with the average concentration during the period indicates 0.29 as the respirable fraction.

At site s-32 the results were quite surprising in that the combined cyclone and filter indicate a $\mathrm{Pu}^{39}$ concentration about three times that found at the closer in S-8 site. The staplex, at s-32 did not come out in agreement with the cyclone set, but this may be due to the abbreviated sampling period, and the difference in sampler height, as described earlier. The respirable fraction was 0.35 .

Although the results from sites $s-18$ and $s-34$ were too low to give meaningful respirable fractions, the activity found in the s-34 cyclone suggests that the $\mathrm{Pu}^{38}$ concentration in the air there was about an order of magnitude higher than at s-18. The Staplex again, as at $\mathrm{s}-32$ was much lower in concentration. 
Not too many conclusions can be drawn from so few data. The respirable fraction of Puss9 in the air near the Rocky Flats plant seems to be reasonably consistent at about 0.2 to 0.4 . This is not in very close agreement with the value of .05 to .07 derived from particle size measurements on filter papers, described earlier (12). Although there is no direct proof at this time, we feel that this discrepancy is due mainly to a discrimination against smallex particles, in the filter paper work. In the filters studied very few particles of less than $2 \mu \mathrm{m}$ were found to contain plutonium. Whether this is due to the actual method of particle sizing, cannot be determined. In any case, this sort of bias would lead to lower respirable fractions, as observed.

The 0.2 to 0.4 respirable fraction determined in this study。 is not too different from the value assumed in the derivation of the maximum permissible concentration (18). Hence the concentrations observed can be compared with the published mpcs. The highest value during the period of this experiment, almost $19 \mathrm{fCi} / \mathrm{m}^{3}$ at s-32, was more than $30 \%$ of the most conservative guideline for general population exposure mentioned earlier. 
The mean concentrations seen at the two highest level sites suggest that the major source of resuspended plutonium is probably not within the plant site, but somewhere between $\mathrm{s}-8$ and $\mathrm{s}-32$, although the wind patterns during these tests makes this conclusion somewhat tenuous. Finally, in comparing the staplex results with the cyclone + filter at the two stations s-32 and s-34 we believe that there must be a substantial vertical gradient in $\mathrm{Pu}^{2}{ }^{30}$ concentration, at least in the range of 3 to 8 feet above the ground. The agreement at S-8, where the samplers were all at about the same elevation reinforces this very tentative conclusion. 
(1) Report on the Dow Rocky Flats Fire: Implications of Plutonium Releases to the Public Health and Safety. Colorado Committee for Environmental Information, Subcommittee on Rocky Flats, Boulder, Colorado January 13,1970 .

(2) Krey, P. W. and Hardy, E.P., Jr。 Plutonium in Soil Around the Rocky flats Plant USAEC Report HASL-235, August 1, 1971

(3) Langham W. and Anderson, E.C. Entry of Radioactive Fallout into the Biosphere and Man Bull. of the Swiss Acad. Med. Sci., 14, 434 (1958)

(4) Dolphin, G.W.

The Biological Problems in the Radiological Protection of Workers Exposed to $\mathrm{Pu}^{23 \theta}$

Health Physics, 20, June (1971) pp 549-557

(5) Volchok, H. L.

Resuspension of $\mathrm{Pu}^{3}$ in the Vicinity of Rocky Flats, Colorado

Environmental Plutonium Symposium。 Los Alamos Scientific

Laboratory, August 1971

(In Press)

(6) Lippmann, M. and Haxris, W.B.

Size-Selective Samplers for Estimating Respirable Dust concentrations

Health Physics, 8, (1962), pp 155-163

(7) "Recommendations of the British Medical Research Council

Panels Relating to Selective Sampling, March 1952"

in: Inhaled Particles and Vapors

(Pergamon Press, London, 1961), p. 475

(8) American Conference of Government Industrial Hygienists "Threshold Limit Values of Airborne Contaminants and Intended Changes" (1970) 
(9) Watson, H. H.

Dust Sampling to Simulate the Human Lung

British J. of Ind. Med. 10:93 (1953)

(10) Beeckmans, J.M.

Correction Factor for Size-Selective Sampling Results

Based on a New Computed Alveolar Curve

Ann. Occup. Hyg . 8:221 (July 1965)

(11) Mercer, T.T.

Air Sampling Problems Associated with the Proposed Lung Model

Presented at the 12 th Annual Bioassay and Analytical Chemistry Meeting, Gatlinburg, Tenn。Oct.13, 1966

(12) Nathans, M. W. and Holland, W. D.

Analysis of $30 \mathrm{Pu}$ Particles collected Near the Rocky Flats Facility

Final Report TLW-6105, AEC Contract No. NY 72-1915

October 25, 1971

(13) Dunmore, J.H., R.J. Hamilton and D.S.G. Smith

An Instrument for the Sampling of Respirable Dust for Subsequent Gravimetric Assessment

J. Sci. Instr. 41, 669-672 (1964)

(14) Wright, B. M.

A Size Selective Sampler for Airborne Dust

British J. Ind.Med。11, 284-288 (1954)

(15) Davies, C. N.

Dust Sampling and Lung Disease

British J。Ind. Med. 9. 120 (1952)

(16) Hyatt, E.C., H.F. Schulte, C.R. Jensen, R.N。 Mitchell and G. H. Ferran

A Study of Two-Stage Air Samplers Designed to Similate the Upper and Lower Respiratory Tract

13th International Congress on Occupational Health (1960) 
(17) Boss, M. R. and Steward, L. M.

Semiannual Report: Environmental Safeguard 1971 RFP-ENV-71A, November 1, 1971

(18) Report of Committee II on Permissable Dose for Internal Radiation (1959)

Recommendations of ICRP

ICRP Publication 2

Pergamon Press 
ANALYSES OF QUALITY CONTROL SAMPLES AT HASL AND A
CONTRACTOR LABORATORY DURING I97I

By E. Hardy (HASL)

ABSTRACT

Samples of biological material and fallout, analyzed at HASL and by a contractor laboratory include quality control samples which are submitted as blinds. The checks consist of blanks, natural samples analyzed repeatedly from year to year, replicates or splits of unknown, spikes, and duplicate samplings. This report summarizes quality control data for ashed bone, diet and fallout samples analyzed for $\mathrm{Sr}^{90}, \mathrm{Sr}^{\mathrm{ag}}$, $\mathrm{Cs}^{137}$, and $\mathrm{Ca}$ during 1971.

\section{INTRODUCTION}

Analyses performed either at HASI or by contractor laboratories for HASL, include samples that are used to assess the quality of the data. Each group of unknowns submitted for analysis consists of check samples which constitute about ten percent of the total number of samples.

Quality control results for stratospheric and surface air samples are regularly presented in other sections of this Quarterly report. Results for check samples submitted with monthly fallout collections, diet and human bone samples, 
however, are presented on an annual basis $(1,2)$. This report covers these types of quality control samples analyzed during 1971 as well as results of duplicate samplings of tap water and monthly fallout.

The actual samples used in quality control consist of blanks, natural samples analyzed repeatedly over several years, replicates or splits of unknowns, and spiked samples. In the accompanying tables, samples analyzed at the Health and Safety Laboratory are identified as HASL while those analyzed at a contractor laboratory are identified by the code letters (NN).

Following is a summary of quality control data for bone ash, vegetation ash, ion exchange resin and simulated pot samples analyzed during 1971. Results of individual analyses and average values for 1 . blanks, 2. natural samples, 3. duplicates and 4. spikes, are given in tables 1 through 4. Results for duplicate sample collections are presented in table 5.

\section{SUMMARY OF RESULTS}

1. Blanks

Fourteen blind calcium phosphate samples (10 grams each) were analyzed for $\mathrm{Sr}^{90}$ at HASL during 1971. The average value was $0.05 \pm 0.05 \mathrm{dpm} \mathrm{Sr}^{90}$ per gram. The error term is one standard 
deviation from the mean. This average value is the same as that reported in 1970 .

Seventy gram aliquots of Dowex 50W-X12, 50-100 mesh, cation exchange resin, conditioned at HASL and used in monthly fallout collections employing a funnel and ion-exchange column system, were analyzed as blanks. Contractor laboratory NN analyzed 17 unexposed resin samples during the course of the FY'7l contract period and reported, on the average, $0.8 \pm 1.3 \mathrm{dpm}$ $\mathrm{Sr}^{90}$. Twelve resin blanks were analyzed at HASI and the average during 1971 was $0.5 \pm 0.3 \mathrm{dpm} \mathrm{Sr}^{\circ \circ}$. These values are not significantly different from those reported in 1970. These blank levels are considered acceptable in terms of the activity level ( 2 dpm) for a column that has received a deposit of $0.01 \mathrm{mCi} \mathrm{Sr}^{90}$ per $\mathrm{km}^{2}$ which is the lowest monthly rate reported. The simulated pot collections analyzed as blanks showed similar Sr90 levels. The average of 17 analysis by contractor NN was $0.6 \pm 0.9 \mathrm{dpm} \mathrm{Sr}^{90}$ while the average of 4 analyses at HASL was $0.6 \pm 0.6 \mathrm{dpm} \mathrm{sr}^{90}$

Blank resin and simulated pot samples analyzed for $\mathrm{Sr}^{89}$ in 1971 by contractor laboratory $N N$ averaged $0.9 \pm 2.2$ and $0.4 \pm 0.3 \mathrm{dpm}$, respectively. The mean and standard deviation for the blank resin are higher than reported in 1970 due to one anomalously high value. 
The 1971 blank data are summarized in the following table:

\section{BLANKS}

\begin{tabular}{|c|c|c|c|c|c|}
\hline \multirow[b]{2}{*}{ Matrix } & \multirow[b]{2}{*}{ Lab. } & \multirow{2}{*}{$\begin{array}{c}\text { No. of } \\
\text { Analyses }\end{array}$} & \multicolumn{2}{|c|}{ Avg. $\mathrm{dpm} \mathrm{Sr}^{90}$} & \multirow{2}{*}{$\begin{array}{l}\text { Avg. dpm } \\
\text { Sr }{ }^{89} \\
\text { per sample }\end{array}$} \\
\hline & & & per $\mathrm{g}$ & per sample & \\
\hline $\begin{array}{l}\text { Calcium } \\
\text { phosphate }\end{array}$ & HASL & 14 & $0.05 \pm 0.05$ & & \\
\hline \multirow[t]{3}{*}{ Resin } & NN & 17 & & $0.8 \pm 1.3$ & \\
\hline & HASI & 12 & & $0.5 \pm 0.3$ & \\
\hline & NN & 15 & & & $0.9 \pm 2.2$ \\
\hline \multirow[t]{3}{*}{ Pot } & NN & 17 & & $0.6 \pm 0.9$ & \\
\hline & HASL & 4 & & $0.6 \pm 0.6$ & \\
\hline & NN & 10 & & & $0.4 \pm 0.3$ \\
\hline
\end{tabular}

2. Natural Samples

Ten grams aliquots of ashed natural samples of human and animal bone, milk, and vegetation have been analyzed for $\mathrm{Sr}^{\circ}{ }^{\circ}$ and $\mathrm{Ca}$ repetitively at HASI for a number of years. The following table compares the average of values reported in 1971 with the average of all results for each sample to the end of 1971. The error term accompanying each result is one standard deviation of the mean. Most of these samples have been used in quality control at HASL for ten or more years. 
NATURAL SAMPLES (HASL)

\begin{tabular}{|c|c|c|}
\hline & Orig. & Avg. dpm $\mathrm{Sr}^{90}$ per $\mathrm{g}^{*}$ \\
\hline Matrix & HASL NO. & All analyses \\
\hline
\end{tabular}

$\begin{array}{lllllr}\text { Human bone ash } & 5407 & 1.4 \pm 0.2 & (6) & 1.3 \pm 0.1 & (97) \\ \text { Milk ash } & 7604 & 2.3 \pm 0.1 & (2) & 2.2 \pm 0.2 & (77) \\ & 9598 & 1.4 & (1) & 2.0 \pm 0.3 & (9) \\ \text { Vegetation ash } & 9236 & 8.2 & (1) & 9.2 \pm 0.8 & (21) \\ & \text { V0169 } & 12.7 \pm 0.1 & (3) & 13.3 \pm 1.0 & (32) \\ & \text { V0360 } & 16.6 \pm 0.4 & (3) & 16.0 \pm 1.1 & (13)\end{array}$

*No. of analyses in parenthesis

In two cases (milk ash sample No. 9598 and vegetation ash sample No. 9236) the 1971 average is lower than the average of all available analyses, considering the limits of error. For the other samples the two values agree within the limits of error reported. All values have been corrected for decay to a common date assigned to each sample.

\section{Duplicates}

Split blind duplicate human bone and food ash samples were analyzed for $\mathrm{Sr}^{90}$ at HASL during 1971. Average percent standard deviations from the means were less than ten percent as shown in the following table: 


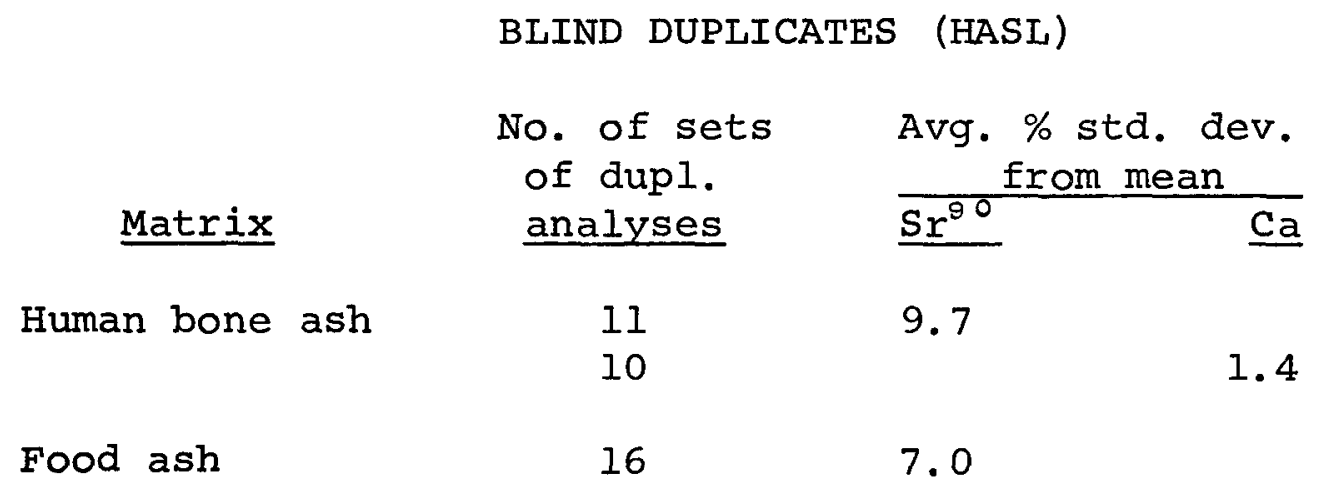

The overall analytical reproducibility is considered satisfactory for these types of samples and activity levels.

\section{A. Spikes}

Known amounts of standardized $\mathrm{Sr}^{90}$ and $\mathrm{Sr}^{89}$ solutions are added to simulated pot and unexposed resin samples and submitted with unknowns to HASL and the contractor laboratory. Average recoveries, activity found $\div$ activity added $\times 100$, for analyses performed during 1971 are summarized below. The error term is one Gaussian standard deviation from the mean.

\section{SPIKED SAMPLES}

$\begin{array}{ccccc}\text { Type sample } & \begin{array}{c}\text { No. of } \\ \text { pairs }\end{array} & & \text { L S } \mathrm{Sr}^{90} \text { recovered } \\ \text { Resin } & 35 & & \text { HASL } \\ & 12 & & 102 \pm 19 \\ \text { Pot } & 34 & 80 \pm 17 & \\ & 7 & & 97 \pm 11\end{array}$




$$
\% \mathrm{Sr}^{89} \text { recovered (Lab. NN) }
$$

\begin{tabular}{|c|c|c|c|c|}
\hline \multirow[b]{2}{*}{ Type sample } & \multirow{2}{*}{$\begin{array}{r}\text { No. of } \\
\text { pairs }\end{array}$} & \multicolumn{3}{|c|}{ (activity level-dpm) } \\
\hline & & $10-20$ & $100-200$ & $\underline{500-1000}$ \\
\hline Resin & 6 each & $84 \pm 30$ & $90 \pm 27$ & $92 \pm 14$ \\
\hline Pot & & $90 \pm 40$ & & \\
\hline & $6 \mathrm{e}$ & & $92 \pm 27$ & $72 \pm 24$ \\
\hline
\end{tabular}

Average recoveries of $\mathrm{Sr}^{0}$ by the contractor laboratory during 1971 continued to be low as in 1970. A study of this problem is currently underway.

Recovery values for $\mathrm{Sr}^{89}$ in the 10-20 dpm range are less variable than in 1970. The relatively larger error terms associated with the mean recovery values for $\mathrm{Sr}^{89}$ indicate the inherently less precise procedure of determining $\mathrm{Sr}^{89}$ by difference. In general the $\mathrm{Sr}^{89}$ recoveries over the 10-1000 dpm range are considered acceptable for the program.

\section{Duplicate Sampling}

For many years duplicate fallout collectors have been exposed for monthly periods on the roof of HASL to test sampling reproducibility. Duplicate tap water samples from the HASL have also been collected daily and composited on a monthly basis, for the same purpose. Analytical values for duplicate sample collections in 1971 which are given in Tables $5 \mathrm{~A}$ and 5B may be summarized as follows: 


\section{DUPLICATE MONTHLY SAMPLE COLLECTIONS}

$\underline{\text { Sample type }} \begin{array}{r}\text { No. of } \\ \text { pairs }\end{array} \frac{\text { Avg. \% dev. fr. mean }}{\underline{S r^{90}} \underline{\mathrm{CS}^{137}}} \frac{\text { Range }}{\underline{\mathrm{Sr}^{90}} \underline{\mathrm{CS}^{137}}}$

Fallout

9

2.8

$0-13 \%$

10

4.1

$0.5-5.5 \%$

Tap water

11

3.4

$0-11 \%$

In both cases sampling reproducibility is less than five percent. 


\section{REFERENCES}

1. Harley, J. H.

Errors in Measurement

USAEC Report HASI-105, p. 132, January (1961)

2. Hardy, E.

USAEC Reports: HASL-122, p. 197, April (1962)

HASL-140, p. 248, October (1963)

HASL-158, p. 278, April (1965)

HASL-165, P. 332, January (1966)

HASL-174, p. I-16, January (1967)

HASL-184, p. I-224, January (1968)

HASL-204, p. I-47, January (1969)

HASL-217, p. I-130, January (1970)

HASL-239, p. I-23, January (1971) 
Page

1.) BLANKS
A. Calcium Phosphate
$: \mathrm{Sr}^{90}$
B. Ion Exchange Resin
: $\mathrm{Sr}^{\circ 0}$
C. Simulated Pot Collection
$=\mathrm{Sr}^{90}, \mathrm{Sr}^{89}$
I -28
$I-29$
I -30

2.) NATURAL SAMPLES
A. Human Bone Ash
(No. 5407)
$: \mathrm{Sr}^{90}, \mathrm{Ca}$
I - 31
B. Milk Ash
C. " "
(No. 7604)
: $\mathrm{Sr}^{90}, \mathrm{Ca}$
$I-32$
D. Vegetation
(No. 9598) : $\mathrm{Sr}^{90}, \mathrm{Ca}$
$I-33$
E. "
Ash (No. 9236) $: \mathrm{Sr}^{90}, \mathrm{Ca}$
$"(\mathrm{No}, \mathrm{VOl69}): \mathrm{Sr}^{90}, \mathrm{Cs}$
$I-34$
F.
$I-35$
(No. V0360) $=\mathrm{Sr}^{90^{\circ}}$
I -36

3.) BLIND DUPLICATES
A. Human Bone Ash
B. Vegetation and Food Ash
: $\operatorname{Sr}_{90}^{90}, \mathrm{Ca}$
I - 37
I -38

4.) SPIKES
A. Ion-Exchange Resin
$=\operatorname{Sr}^{\circ 0}$
$I-39$
B. Simulated Pot Collections : $\mathrm{Sr}^{\circ 0}$
$I-40$
C. Ion-Exchange Resin
$\mathrm{Sr}^{89}$
$I-41$
D. Simulated Pot Collections $: \mathrm{Sr}^{89}$
I -42

5.) DUPLICATE SAMPLING

A. Tap Water (Monthly Composites : $\mathrm{Sr}^{90}, \mathrm{Cs}^{137}$ I -43

B. Fallout (Monthly Pot Collections) $=\operatorname{Sr}^{90}$ I -44 
1. BLANKS

A. Calcium Phosphate, $\mathrm{Sr}^{90}$

Data Period: January - December 1971

Laboratory: HASL

$$
\begin{aligned}
& \text { dpm } \mathrm{Sr}^{90} \\
& \text { per gram } \\
& 50.03 \\
& 0.03 \\
& 50.04 \\
& 50.01 \\
& 0.06 \\
& \leq 0.03 \\
& \leq 0.02 \\
& \leq 0.02 \\
& 0.19 \\
& 0.06 \\
& 0.02 \\
& 0.09 \\
& 0.09 \\
& 0.06
\end{aligned}
$$

14 analyses: avg $0.05 \pm 0.05 \mathrm{dpm} \mathrm{sr}^{90}$ per gram

*A less than or equal to sign (s) precedes the Poisson standard deviation in those cases where the value obtained was less than the error term or less than zero. For purposes of averaging, the less than or equal sign was disregarded. 
1. BLANKS (cont'd)

B. Ion Exchange Resin, $\mathrm{Sr}^{89}$ and $\mathrm{Sr}^{90}$

Data Period: December 1970 - November 1971: Lab NN January 1971 - December 1971: HASL

---- apm $\mathrm{Sr}^{90}--$

$\underline{\text { Lab NN } \quad \text { HASL }}$

$\begin{array}{rc}1.2 & \leq 0.2 \\ 1.8 & 0.6 \\ 2.0 & \leq 0.2 \\ \leq 0.3 & \leq 0.2 \\ \leq 0.1 & \leq 0.2 \\ 5.4 & \leq 0.2 \\ \leq 0.2 & 1.1 \\ \leq 0.1 & 0.6 \\ \leq 0.1 & 1.0 \\ \leq 0.3 & 0.6 \\ 0.3 & 0.5 \\ \leq 0.3 & 0.8 \\ 0.3 & 12 \text { analyses } \\ \leq 0.2 & \text { avg. } 0.5 \pm 0.3 \mathrm{dpm} \mathrm{sr} 90 \\ \leq 0.1 & \\ \leq 0.3 & \end{array}$

dpm $\mathrm{Sr}^{89}$

Lab NN

$$
\leq 0.2
$$

$\leq 0.1$

$\leq 0.3$

$\leq 0.1$

$\leq 0.3$

$\leq 0.1$

$\leq 0.3$

$\leq 0.9$

$\leq 0.3$

$\leq 0.5$

8.9

$\leq 0.1$

$\leq 0.4$

$\leq 0.3$

$\leq 0.1$

$17 \frac{\leq 0.3}{\text { analyses }}$

avg. $0.8 \pm 1.3 \mathrm{dpm} \mathrm{sr} 90$

$15 \overline{\text { analyses }}$

avg. $0.9 \pm 2.2 \mathrm{dpm} \mathrm{Sr}^{89}$ 
1. BLANKS (cont'd)

C. Simulated Pot Collection, $\mathrm{Sr}^{89}$ and $\mathrm{sr} 90$

Data Period: December 1970 - November 1971: Lab NN January 1971 - December 1971: HASL

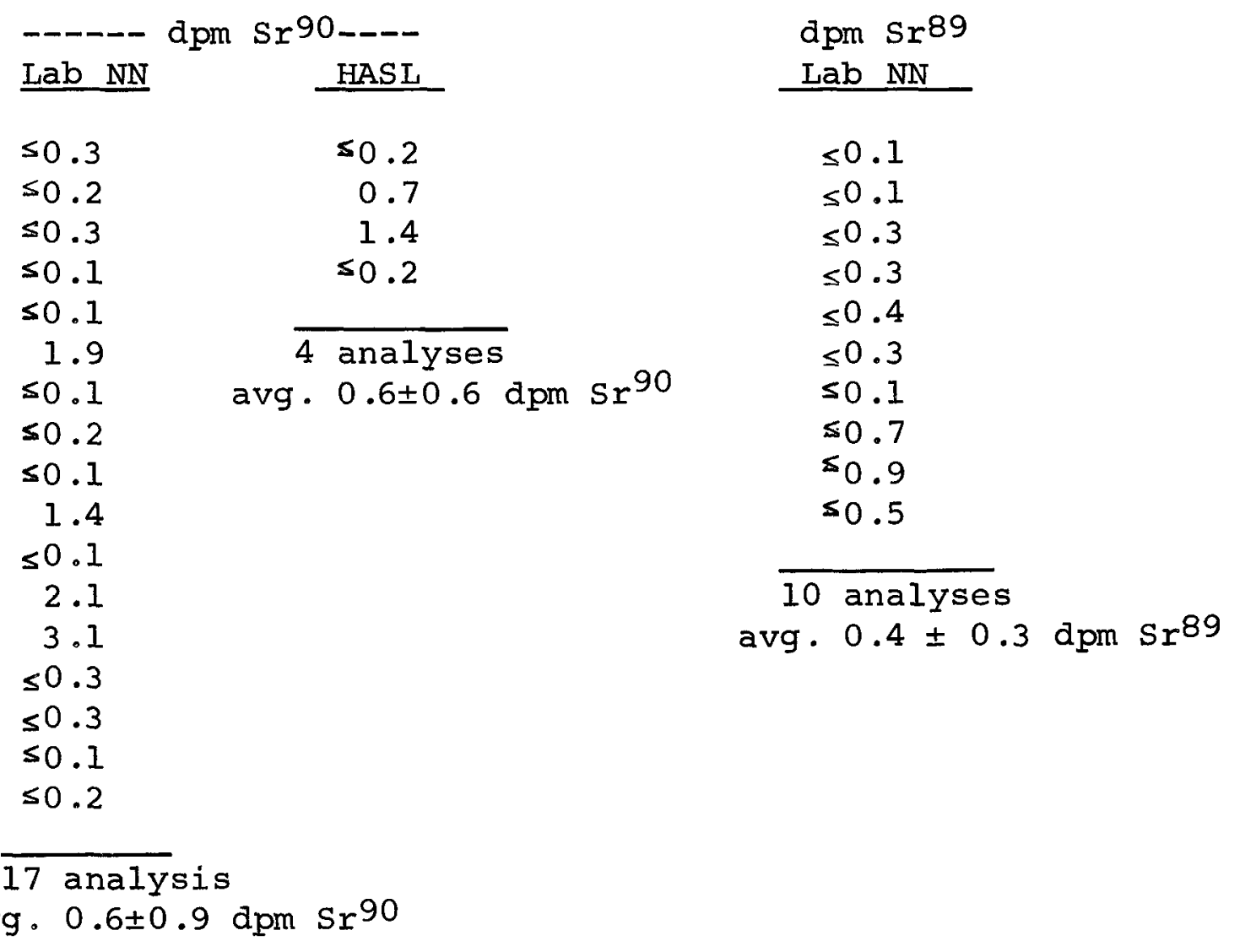


2. NATURAL SAMPLES

A. Human Bone Ash (Orig. HASL No. 5407), Sr90 and Ca

Data Period: January - December 1971

Laboratory: HASL

\begin{tabular}{|c|c|}
\hline $\begin{array}{l}\text { dpm } \mathrm{sr}^{90} \\
\text { per gram (1) }\end{array}$ & $\% \mathrm{Ca}$ \\
\hline 1.24 & 37.5 \\
\hline 1.31 & 37.0 \\
\hline 1.51 & 37.4 \\
\hline 1.76 & 37.4 \\
\hline 1.17 & 36.2 \\
\hline 1.33 & 37.0 \\
\hline
\end{tabular}

(1) decay corrected to $7 / 1 / 57$

Avg。 of results from July 1957 to December 1971(2)

$$
\begin{aligned}
& \text { dpm } \mathrm{Sr}^{90} \text { per gram: } 1.28 \pm 0.14(10.9 \%) \text { - decay corrected } \\
& \text { to } 7 / 1 / 57 \\
& 0.89 \pm 0.10 \quad-\text { decay corrected } \\
& \text { to } 1 / 1 / 72 \\
& \text { based on } 97 \text { blind analyses at HASL } \\
& \text { \% Ca: } \quad 36.5 \pm 1.1(3.0 \%) \\
& \text { based on } 43 \text { blind analyses at HASL }
\end{aligned}
$$


2. NATURAL SAMPLES - cont'd)

B. Powdered Milk Ash (Orig. HASL No. 7604), $\mathrm{Sr}^{90}$ and Ca

Data Period: January - December 1971

Laboratory: HASL

dpm $\operatorname{Sr}^{90(1)}$

per gram

$\% \mathrm{Ca}$

2.19

14.5

2.32

14.8

(1) decay corrected to $3 / 1 / 59$

Avg. of results from March 1959 thru December 1970(2) dpm $\mathrm{Sr}^{90}$ per gram: $2.21 \pm 0.22(10.0 \%)$ decay corrected to $3 / 1 / 59$

$1.61 \pm 0.16$ decay corrected to $1 / 1 / 72$

based on 77 blind analyses at HASL

\% Ca:

$15.1 \pm 0.6 \quad(4.0 \%)$

based on 47 blind analyses at HASL

(2) error term is one standard deviation of the mean 
2. NATURAL SAMPLES - (cont'd)

C. Milk Ash (Orig. HASL No. 9598), Sr90 and Ca

Data Period: January - December 1971

Laboratory: HASL

dpm $\operatorname{sr} 90(1)$

per gram

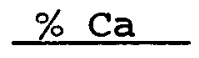

1.44

9.5

(1) decay corrected to $5 / 1 / 59$

Avg. of results from May 1959 thru December 1971(2)

dpm $\mathrm{Sr}^{90}$ per gram: $2.04 \pm 0.29$ (14.2\%) decay corrected to $5 / 1 / 59$

$1.49 \pm 0.21$ decay corrected to $1 / 1 / 72$

based on 9 blind analyses at HASL

$\% \mathrm{Ca}$

$9.8 \pm 0.4(4.1 \%)$

based on 4 blind analyses at HASL

(2) error term is one standard deviation of the mean 
2. NATURAL SAMPLES (cont'd)

D. Vegetation Ash (Orig. HASL No. 9236), $\mathrm{Sr}^{90}$ and Ca

Data Period: January - December 1971

Laboratory: HASL

$$
\begin{aligned}
& \text { dpm } \operatorname{Sr} 90(1) \\
& \text { per gram }
\end{aligned}
$$

8.25

(1) decay corrected to $5 / 1 / 59$

Avg. of results from May 1959 thru December 1971(2)

dpm $\mathrm{Sr}^{90}$ per gram: $9.22 \pm 0.82(8.9 \%)$ decay corrected to

$5 / 1 / 59$

$$
\begin{gathered}
6.74 \pm 0.60 \text { decay corrected to } \\
1 / 1 / 72
\end{gathered}
$$

based on 21 blind analyses at HASL

$\begin{array}{ll}\text { \% Ca: } & 9.7 \pm 0.3(3.2 \%)\end{array}$

based on 12 blind analyses at HASL

(2) error term is one standard deviation of the mean 
NATURAL SAMPLES - (cont' $d$ )

E. Vegetation Ash (orig. HASL No. V0169), Sr90 and Ca

Data Period: January - December 1971

Laboratory: HASL

$$
\begin{aligned}
& \text { dpm } \mathrm{sr}^{90(1)} \\
& \text { per gram } \\
& \hline
\end{aligned}
$$

12.6

12.9

12.6

(1) decay corrected to $4 / 1 / 63$

Avg. Of results from April 1963 thru December 1971(2)

dpm $\mathrm{Sr} 90$ per gram: $13.3 \pm 1.0(7.3 \%)$ decay corrected to $4 / 1 / 63$

$$
\begin{gathered}
10.7 \pm 0.8 \quad \text { decay corrected to } \\
1 / 1 / 72
\end{gathered}
$$

based on 32 blind analyses at HASL

$\% \mathrm{Ca} \quad 2.2 \pm 0.1 \quad(4.5 \%)$

based on 6 blind analyses at HASL

(2) error term is one standard deviation of the mean 
2. NATURAL SAMPLES (cont'd)

F. Vegetation Ash (orig. HASL No. V0360), Sr90

Data Period: January - December 1971

Laboratory: HASL

$$
\begin{aligned}
& \begin{array}{l}
\text { dpm } \mathrm{sr}^{90}(1) \\
\text { per gram }
\end{array} \\
& 16.2 \\
& 16.9 \\
& 16.8
\end{aligned}
$$

(1) decay corrected to $5 / 1 / 68$

Avg。 of results from May 1968 to December 1971(2)

$$
\begin{array}{cc}
\text { dpm } \operatorname{sr}^{90} \text { per gram: } & 16.0 \pm 1.1(7.0 \%) \\
& \begin{array}{c}
\text { decay corrected to } \\
5 / 1 / 68
\end{array} \\
14.6 \pm 1.0 & \begin{array}{c}
\text { decay corrected to } \\
1 / 1 / 72
\end{array}
\end{array}
$$

based on 13 blind analyses at HASL

(2) error term is one standard deviation of the mean 
A. Human Bone Ash

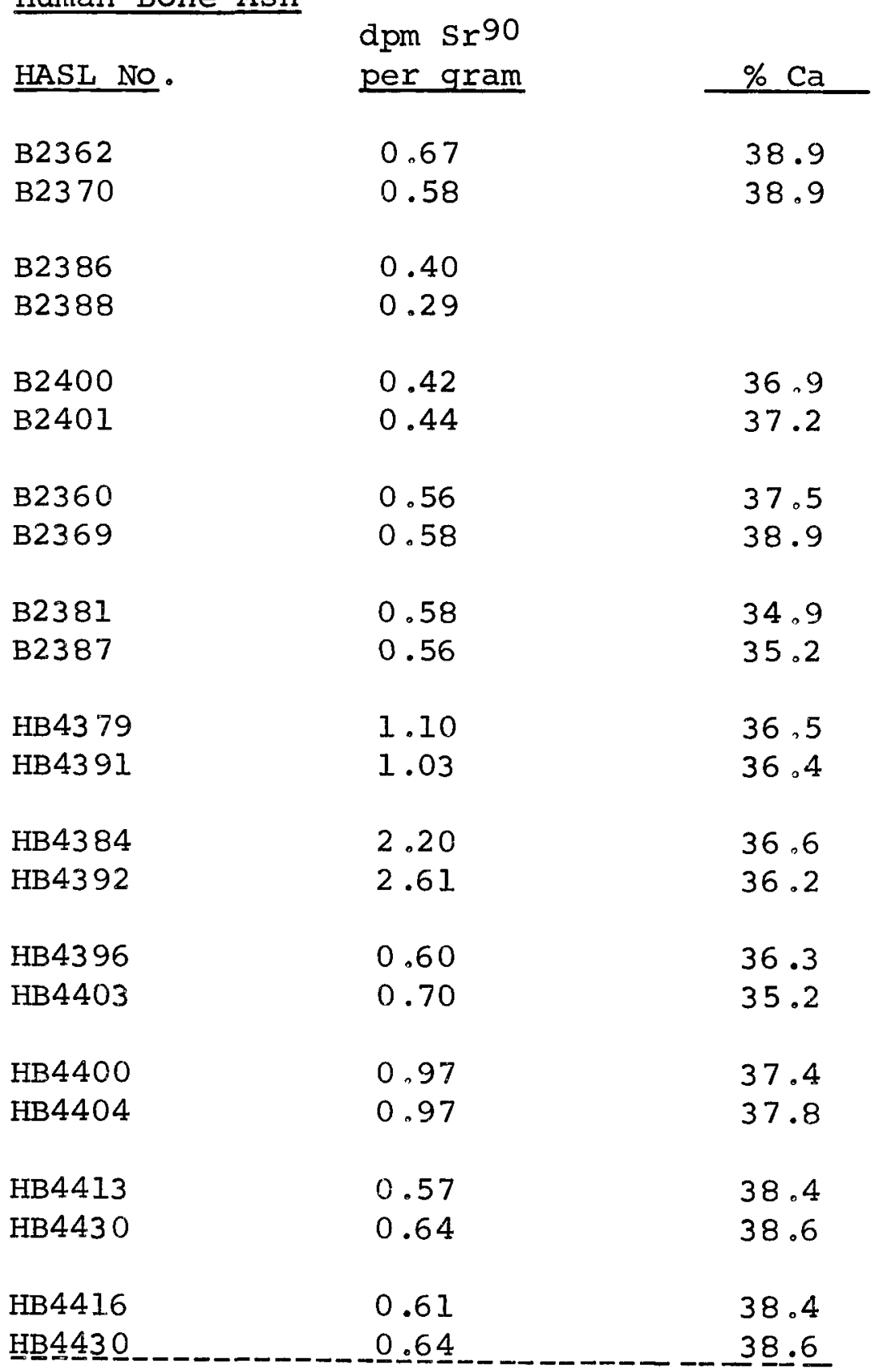

11 Sets of $\mathrm{sr}^{90}$ blind duplicates Avg。\% Standard deviation from mean: $9.7 \%$ range: $0-32 \%$ 10 sets of Ca blind duplicates Avg. \% Standard deviation from mean: $1.4 \%$ range: $0-3.6 \%$ 
3. BLIND DUPLICATES (Cont'd)

B. Vegetation and Food Ash

Data Period: January - December 1971

Laboratory: HASL

$\begin{array}{llll}\text { HASL No. } & \begin{array}{c}\text { dpm Sr } 90 \\ \text { per gram }\end{array} & \text { HASL No. } & \begin{array}{c}\text { dpm Sr } 90 \\ \text { per gram }\end{array} \\ \text { F2789 } & 2.72 & \text { F2882 } & 3.54 \\ \text { F2807 } & 2.77 & \text { F2900 } & 3.26 \\ \text { F2795 } & 1.23 & \text { F2888 } & 0.86 \\ \text { F2808 } & 1.26 & \text { F2901 } & 0.90 \\ \text { F2811 } & 0.56 & \text { F2904 } & 0.47 \\ \text { F2829 } & 0.70 & \text { F2922 } & 0.43 \\ \text { F2817 } & 0.63 & \text { F2910 } & 1.25 \\ \text { F2830 } & 0.64 & \text { F2923 } & 1.12 \\ \text { F2833 } & 5.45 & \text { F2926 } & 4.39 \\ \text { F2851 } & 5.24 & \text { F2944 } & 4.39 \\ \text { F2839 } & 1.37 & \text { F2932 } & 1.41 \\ \text { F2852 } & 1.20 & \text { F2945 } & 1.57 \\ \text { F2855 } & 0.98 & \text { F2952 } & 0.61 \\ \text { F2873 } & 1.06 & \text { F2970 } & 0.69 \\ \text { F2861 } & 0.42 & \text { F2958 } & 1.22 \\ \text { F2874 } & 0.42 & \text { F2971 } & 1.26\end{array}$

16 sets of blind duplicates

Avg. \% standard deviation from mean: $7.0 \%$ range: $0-22 \%$ 
4. SPIKES

A. Ion-Exchange Resin, $\mathrm{Sr}^{90}$

Data Period: December 1970 - November 1971: Lab NN January 1971 - December 1971: HASL

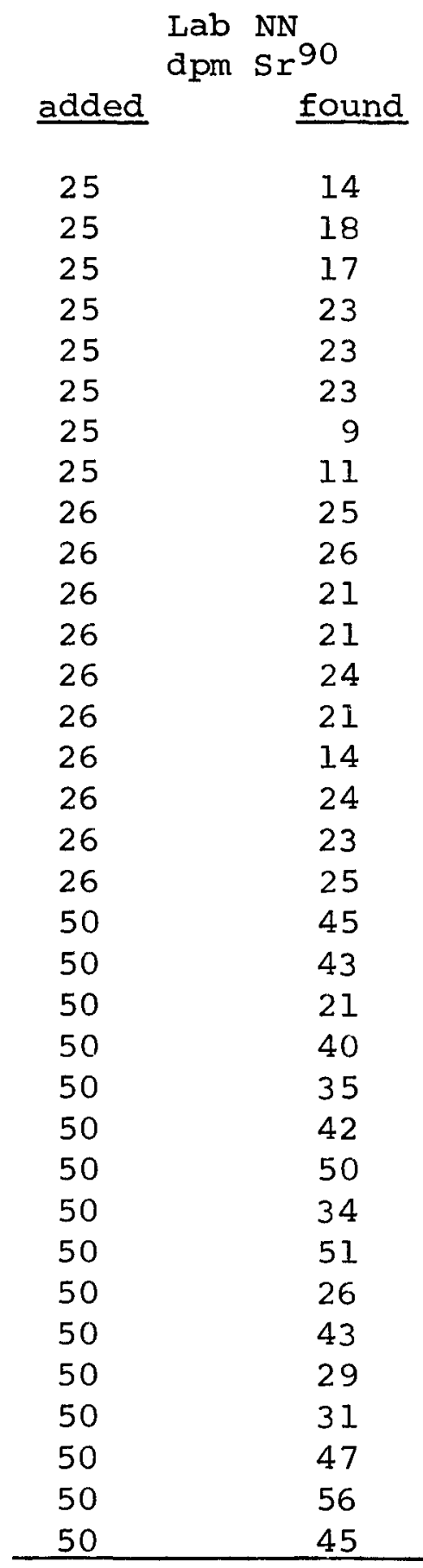

\author{
HASL \\ dpm $\operatorname{sr}^{90}$ \\ added \\ found
}

25

25

25

25

26

26

26

50

50

50

50

50

27

26

25

25

29

25

26

49

49

59

50

47

12 pairs of results: avg \% recovered:102 $\pm 7 \%$

35 pairs of results:

avg. \% recovered: $79 \pm 19 \%$ 
4. SPIKES (Cont'd)

B. Simulated pot Collections, $\mathrm{sr}^{90}$ $\begin{array}{ll}\text { Data Period: } & \begin{array}{l}\text { December 1970 - November 1971: Lab NN } \\ \text { January 1971 - December 1971: HASL }\end{array}\end{array}$

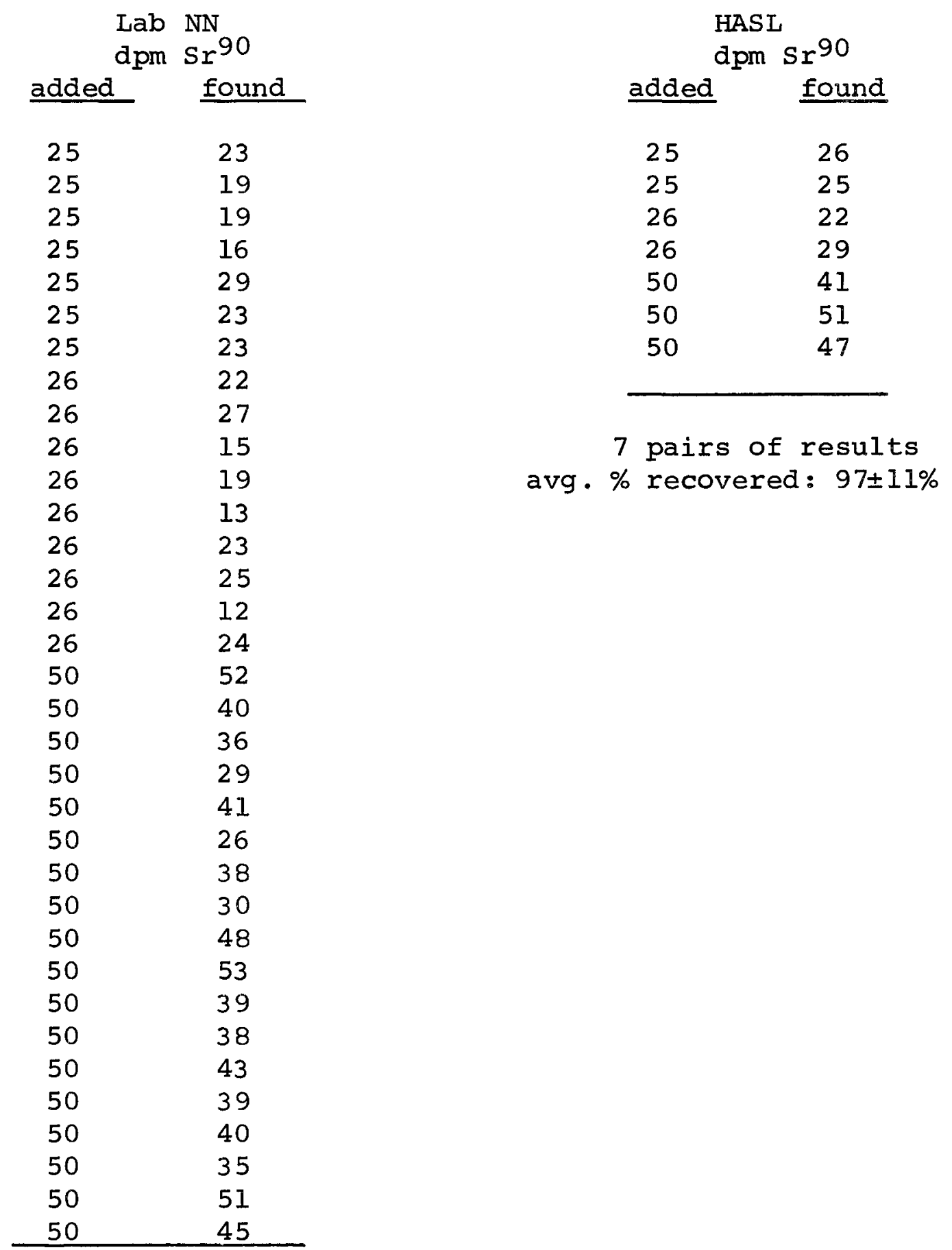

34 pairs of results avg. \% recovered: $80 \pm 17 \%$ 
4. SPIKES (cont'd)

C. Ion-Exchange Resin, $\mathrm{Sr}^{89}$

Data Period: November 1970 - November 1971

Lab : NN

\begin{tabular}{|c|c|c|c|}
\hline \multicolumn{2}{|c|}{ dpm $S^{89}$} & & \\
\hline added & found & & \\
\hline 14 & 12 & & \\
\hline 16 & 10 & 6 pairs of results & \\
\hline 16 & 9 & & \\
\hline 16 & 12 & avg. \% recovered: & $84 \pm 30 \%$ \\
\hline 17 & 14 & & \\
\hline 17 & 24 & & \\
\hline 144 & 161 & & \\
\hline 151 & 110 & 6 pairs of results & \\
\hline 159 & 184 & & \\
\hline 159 & 179 & avg. \% recovered: & $90 \pm 27 \%$ \\
\hline 166 & 83 & & \\
\hline 166 & 131 & & \\
\hline$-\infty-\infty$ & $-\infty-\infty$ & & \\
\hline 755 & 752 & & \\
\hline 763 & 694 & 6 pairs of results & \\
\hline 786 & 743 & & \\
\hline 800 & 829 & avg. \% recovered: & $92 \pm 14 \%$ \\
\hline 800 & 518 & & \\
\hline 808 & 814 & & \\
\hline
\end{tabular}


4. SPIKES (cont'd)

D. Simulated Pot Collections, $\mathrm{Sr}^{89}$

Data Period: November 1970 - December 1971

Lab: NN

\begin{tabular}{|c|c|c|c|}
\hline \multicolumn{2}{|c|}{ dpm $\mathrm{sr}^{89}$} & & \\
\hline added & found & & \\
\hline 14 & 20 & & \\
\hline 16 & 14 & 5 pairs & \\
\hline 16 & 18 & & \\
\hline 17 & 7 & avg. \% recovered: & $90 \pm 40 \%$ \\
\hline 17 & 11 & & \\
\hline----- & $-\infty----$ & & \\
\hline 144 & 190 & & \\
\hline 151 & 139 & 6 pairs of results & \\
\hline 159 & 94 & & \\
\hline 159 & 175 & avg. \% recovered: & $92 \pm 27 \%$ \\
\hline 166 & 115 & & \\
\hline 166 & 147 & & \\
\hline$--\infty-\infty$ & $\cdots-$ & & \\
\hline 755 & 585 & & \\
\hline 763 & 692 & 6 pairs of results & \\
\hline 786 & 604 & & \\
\hline 800 & 685 & avg. \% recovered: & $72 \pm 24 \%$ \\
\hline 800 & 601 & & \\
\hline 808 & 204 & & \\
\hline
\end{tabular}


5. DUPLICATE SAMPLING

A. Tap Water (Monthly Composites)

Data Period: January - December 1971

Laboratory: HASL

\begin{tabular}{lll} 
& dpm $\operatorname{sr}^{90}$ & dpm $\operatorname{Cs} 137$ \\
HASL NO. & per $100 \ell$ & per $100 \ell$ \\
\hline
\end{tabular}

\begin{tabular}{|c|c|c|}
\hline W0464 & 136 & 19.5 \\
\hline W0465 & lost & 19.6 \\
\hline W0467 & 155 & 22.4 \\
\hline W0468 & 157 & 21.1 \\
\hline W0470 & 153 & 16.0 \\
\hline W0 471 & 146 & 16.5 \\
\hline W0472 & 166 & 15.1 \\
\hline W0473 & 166 & 13.9 \\
\hline W04 76 & 156 & 12.4 \\
\hline W0477 & 137 & 13.1 \\
\hline W0478 & lost & 14.1 \\
\hline W0479 & 143 & 14.6 \\
\hline W0486 & 142 & 15.8 \\
\hline W0487 & 138 & 15.3 \\
\hline W0492 & 138 & 18.9 \\
\hline W0493 & 140 & 18.2 \\
\hline W0494 & 118 & \\
\hline W0495 & 120 & \\
\hline W0498 & 113 & 17.6 \\
\hline W0499 & 113 & 18.2 \\
\hline WO500 & 159 & 20.9 \\
\hline W0501 & 160 & 20.1 \\
\hline
\end{tabular}

9 sets of duplicate samplings for $\mathrm{sr} 90$

avg. \% deviation from mean: $2.8 \%$, range $0.0-13 \%$

10 sets of duplicate samplings for $\mathrm{Cs}^{137}$

avg. \% deviation from mean: $4.1 \%$, range $0.5-5.5 \%$

$$
I-43
$$


5. DUPLICATE SAMPLING (cont'd)

B. Fallout (Monthly Pot Collections)

HASL NO.

$$
\text { dpm } \operatorname{sr} 90
$$

P5396

per pot

P5397

15.6

14.6

P543 5

20.0

P5436

20.2

P5465

9.0

P5466

9.1

P5494

6.4

P5495

5.9

P5527

20.7

P5528

20.7

P5560

30.1

P5561

30.0

P5596

22.8

P5597

21.7

P5629

50.6

P5630

50.2

P5680

22.8

P5681

20.4

P5722

32.0

P5723

32.8

P5759

16.1

P5760

17.0

11 sets of duplicate samplings

Avg. \% deviation from mean: $3.4 \%$, range $0-11 \%$ 
$\chi$ STABLE LEAD CONCENTRATIONS IN NEW YORK CITY FOODSTUFFS

D. C. Boger (HASL)

\begin{abstract}
$\underline{\text { ABSTRACT }}$
Nineteen food categories which constitute the typical American diet have been analyzed for stable lead. Three complete diet samplings are reported. The dietary intake of lead obtained from the first study was about $285 \mu \mathrm{g} /$ day, while the intake from the other two studies was between $70-80 \mu \mathrm{g} /$ day. The higher results obtained for the first study are suspect because of possible contamination problems.
\end{abstract}

\title{
INTRODUCTION
}

The National Research Council's Committee on Biological Effects of Atmospheric Pollutants recommended (1) more extensive monitoring of lead in common food items, drinking water, and miscellaneous beverages. The committee's report concluded that the average American consumes more lead in food and beverages than he inhales from the air. our laboratory started a modest program in 1966 to document the stable lead concentrations in the New York City diet. The food categories chosen for analysis were the same as in the HASL Tri-City diet program ${ }^{(2)}$ since these categories constitute a typical American diet. We have completed three diet samplings and each covers a specific time period when the food was purchased and analyzed. These time periods are (a) Fall 1966-Winter 
1967, (b) Fall 1968-Winter 1969, and (c) Fall 1970-Winter 1971。

\section{ANALYSIS}

A. The first diet sampling was analyzed by a method previously reported ${ }^{(3)}$.

B. The method was modified for the second diet sampling. Samples were freeze-dried and then ashed in a low temperature asher (Tracerlab Model LTA 600). The ashed residues were dissolved in $\mathrm{IM} \mathrm{HCl}$ and the lead was extracted into methyl-isopropyl ketone ${ }^{(4)}$ as the iodide complex using Pb-212 tracer to monitor for any losses. Then the organic lead extract was measured directly on an atomic absorption spectrophotometer and the lead values obtained from a calibration curve.

C. The method of analysis was slightly modified for the third diet sampling. The food samples were wet ashed with nitric acid after freeze-drying. The lead was isolated, purified, and measured as outlined in the second diet sampling.

\section{RESULTS AND DISCUSSION}

The lead results for the three diet samplings are reported in Tables I, II, and III. The yearly food intake values for each category were obtained from U. S. Department of 
Agriculture statistics as summarized by Rivera ${ }^{(5)}$. The results for the first diet survey (1966-1967) indicate an average daily intake of about $285 \mu \mathrm{g}$. The results for the second and third diet surveys (1968-1969, 1970-1971) are in fair agreement with each other indicating an average daily intake of 70-80 $\mu \mathrm{g}$. The lead content within a food category can vary by a factor of two from one sampling to another. We believe that the higher lead values obtained in the first diet study may be suspect because of contamination. In the first experiment the samples were prepared for analysis by wet ashing without first freeze-drying the samples. This made it necessary to use large quantities of $\mathrm{HNO}_{3}$ and $\mathrm{H}_{2} \mathrm{O}_{2}$ to solubilize the sample and these reagents contain trace amounts of lead. The blank levels were $2-5 \mu \mathrm{pg} \mathrm{Pb} / \mathrm{l}$ for $\mathrm{HNO}_{3}$ and $50-200 \mu \mathrm{g} / \mathrm{l}$ for $\mathrm{H}_{2} \mathrm{O}_{2}$. Therefore, there is a significant uncertainty when the data were corrected for reagent contamination. In the last sampling the use of $\mathrm{HNO}_{3}$ was restricted and no $\mathrm{H}_{2} \mathrm{O}_{2}$ was used so that contamination was kept to a minimum.

It is evident that our dietary lead results are lower than those of other investigators $(6,7)$. A major problem in any trace metal analysis is contamination and this may represent 
the differences between our results and the other investigators. It should be noted that we have used $\mathrm{Pb}-212$ tracer to monitor for any chemical losses in the procedure and that we employ large sample sizes $(>1 \mathrm{~kg})$ so that sensitivity is not a problem.

Certainly these differences will be studied further, since there is the implication that ambient lead air concentration in urban environments may contribute as much to the lead intake as food. Measurements performed at our laboratory indicate an average lead air concentration of about $2 \mu \mathrm{g} / \mathrm{m}^{3}$ for New York City. Assuming a total daily inhalation volume of $20 \mathrm{~m}^{3}$ the lead air intake would be about $40 \mu \mathrm{g} \mathrm{Pb} /$ day which is comparable to the dietary intake reported in the second and third food samplings.

\section{REFERENCE}

1. Air/Water Pollution Report 9, No. 36, 363 (1971)

2. Rivera, J., and Harley, J. H. HASI Contribution to the Study of Fallout in Food Chains USAEC Report HASI-147 (1964)

3. Bogen, D. C., and Kleinman, M. T. Improved Determination of Microgram Amounts of Lead in Food with a Radioactive Tracer Analyst 92, 611 (1967) 
4. West, P. W., and Coulton, J. K.

Anal. Chim. Acta 6 , 406 (1952)

5. Rivera, $J$.

HASI Diet Studies: First and Second Quarters of 1968

USAEC Report HASL-200 (1968)

6. Kehoe, R。 A.

Arch. Environ. Health $\underline{2}, 418$ (1961)

7. Schroeder, H. A., and Tipton, I.

Arch. Environ. Health 17, 965 (1968) 
Table I

STABLE LEAD IN TOTAL DIET

1966-1967 Sampling

\section{Category}

Fresh Fish

Shellfish

Poultry

Meat

Eggs

Fresh Fruit

Canned Fruit

Fresh Vegetables

Canned Vegetables

Root Vegetables

Potatoes

Macar oni

Rice

Juice

Dry Beans

Flour

Bakery Products

Whole Grain Products

MI1k
Year ly Intake (kg)

8

1

20

79

15

59

11

48

22

10

38

3

3

28

3

34

44

11

200

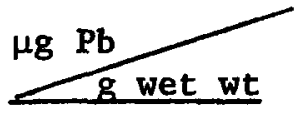

0.16

0.31

0.30

0.42

0.22

0.072

0.25

0.12

0.44

0.068

0.17

0.077

0.044

0.091

0.024

0.041

0.39

0.13

0.038
Total $\mu \mathrm{g} \mathrm{Pb}$

yr

1280

310

6000

33180

3300

4250

2750

5760

9680

680

6460

230

130

2550

70

1390

17160

1430

7600 


\section{Table II}

\section{STABLE LEAD IN TOTAL DIET}

\section{8-1969 Sampling}

\section{Category}

Fresh Fish

Shellfish

Poultry

Meat

Eggs

Fresh Fruit

Canned Fruit

Fresh Vegetables

Canned Vegetables

Root Vegetables

Potatoes

Macaroni

Rice

Juice

Dry Beans

Flour

Bakery Products

Whole Grain Products

Mi 1k
Year 1y

Intake $(\mathrm{kg})$

8

1

20

79

15

59

11

48

22

10

38

3

3

28

3

34

44

11

200

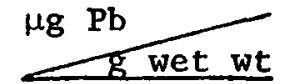

0.049

N.A.

0.042

0.060

0.045

0.063

0.17

0.059

0.033

0.039

0.089

N.A.

0.020

N.A.

0.049

0.022

N.A.

0.050

0.016
Tota1 $\mu \mathrm{g} \mathrm{Pb}$

yr

390

840

4740

680

3720

1870

2830

730

390

3380

60

150

750

550

3200

N.A.: Not analyzed. 


\section{Table III}

STABLE LEAD IN TOTAL DIET

1970-1971 Samp1ing

Category

Fresh Fish

Shellfish

Poultry

Meat

Eggs

Fresh Fruit

Canned Fruit

Fresh Vegetables

Canned Vegetables

Root Vegetabiles

Potatoes

Macaroni

Rice

Juice

Dry Beans

Flour

Bakery Products

Whole Grain Products

Milk
Year ly

Intake (kg)

8

1

20

79

15

59

11

48

22

10

38

3

3

28

3

34

44

11

200
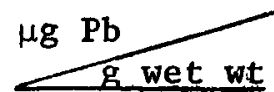

0.057

0.19

0.068

0.038

0.052

0.041

0.19

0.035

0.060

1320

0.041

410

1940

160

0.052

0.11

330

2410

0.086

0.11

330

1090

4400

910

4200 


\title{
Comparison of the Original and Modified \\ High-Volume-3000 Air Ejector Samplers
}

by

T.B. Ashenfelter and K. Telegadas

Alr Resources Laboratories

National Oceanic and Atmospheric Administration

Silver Spring, Maryland 20910

\begin{abstract}
A modification of the High-Volume- 3000 air ejector sampler (HV3K) has been developed and flight tested against an original HV3K sampler. Results indicated the original sampler became contaminated with radioactive debris during its ascent to sampling altitude. This confirmed the earlier results reported by Ashenfelter and Telegadas (1970). The modifled HV3K sampler is considered to be contamination-free during its ascent to sampling altitude.
\end{abstract}


Comparison of the Original and Modified

High-Volume-3000 Air Ejector Samplers

by

T.E. Ashenfelter and $K$. Telegadas

Air Resources Laboratories

National Oceanic and Atmospheric Administration

Silver Spring, Maryland 20910

\section{Introduction}

The U.S. Atomic Energy Commission balloon-borne atmospheric sampling program, Projects Cold Ash and Hibal, (Krey and Kleinman, 1970) had employed a High Volume-3000 Sampler (HV3K) to collect radioactive samples at an altitude of $41 \mathrm{~km}$. Ashenfelter and Telegadas (1970) questioned the integrity of this sampler. They demonstrated that during the sampler's ascent to collection altitude, air was forced down the diffuser tube, through the filter paper and out the inlet door, if the inlet door was partially open. This would lead to contamination of the filter paper (IPC-1478) with fission products which were and still are more abundant at lower altitudes. These sam- . plers were taken out of operation as of October 1969 and the scientific community alerted to the questionableness of past data based on the HV3K sampler collections (Krey and Kleinman, 1970).

A modification of the original HV3K samplers was made by Ashenfelter by redesigning the sampler doors to make them air tight. This report describes the modified sampler and gives the results of the intercomparison test of the original and modifled sampler.

$$
I-54
$$




\section{Description of the Modified Sampler}

A schematic diagram of the modified sampler is shown in Figure 1 . This sampler is the same as the original sampler reported by Ashenfelter and Telegadas (1970) with two exceptions. The inlet and outlet doors were redesigned and a pressure relief port installed into the body of the sampling module.

In the original sampler, the inlet and outlet doors were spring loaded and operated independently of one another. During ascent of the module, the outlet door was fastened in an open position and the inlet door was fastened in a closed position. In the original design, the outlet door could only be actuated in one direction whereas the inlet door could be actuated in both directions. At about $29 \mathrm{~km}$, the inlet door was opened by a firing mechantsm as the system continued to ascend to float altitude of about $41 \mathrm{~km}$. At sampling altitude air was pumped through the filter media for a predetermined time. Upon termination of sampling, the inlet and outlet doors were closed and the system descended by parachute.

It was observed that when the inlet door was secured in its closed position, it would not, in all instances, make a proper seal with the sampling module body (Ashenfelter and Telegadas 1970). Whenever this situation existed, a small fraction of the air intercepted by the diffuser tube during ascent would be forced through the sampling module by ram air pressure (ascent velocity $\sim 5 \mathrm{~m} \mathrm{sec}^{-1}$ ). If the sampler system passed through a relatively high level of radioactivity, the 
filter paper would become contaminated, such that fictitiously high concentrations of fission products would be reported as having been sampled at float altitude.

The sampling doors were redesigned and connected to pneumatic actuators and are now in a closed position during ascent. At sampling altitude the high pressure air ejector pump gas supply is turned on which operates the actuators to open both doors simultaneously and also functions the air ejector to pull air through the filter paper. At termination of sampling, the gas supply is turned off and a tight closure of the inlet and outlet doors is assured by the return spring within the pneumatic actuator. The package then descends by parachute. During ascent and descent, the sampling module doors are in an air tight configuration. To equalize pressure between the inside of the module and the ambient air, a pressure relief port was installed. A hole, $5 \mathrm{~cm}$ in diameter, was cut into the body of the sampling module and a screened plug containing 3 layers of IPC-1478 filter paper was inserted.

Comparison of the Original and Modified Samplers

On December 12, 1970, an intercomparison test involving the original and modified HV3K units was undertaken at San Angelo, Texas $\left(31^{\circ} \mathrm{N}\right)$. The experimental sampling configuration was similar to that shown in Figure 1 with several exceptions. First, the gas supply was not flown since no sampling would take place at float altitude. Second, 
an original HV3K sampler was placed with its diffuser, also in a vertical position, directly below the modified sampler shown in Figure 1. In anticipation of low flow rates during ascent, the two PR-3 60 degree blade flowmeters were replaced by more sensitive PR-3 30 degree blade flowmeters. The flow rate through the filter media could be obtained by both on-board recording and telemetry of flowmeter rotational speed. On a single flight therefore, it was planned to have both sampling modules ascend to an altitude of $30 \mathrm{~km}$ and then descend.

The rigging crew of Detachment 31 , 6th Weather Wing, U.S. Air Force at Goodfellow AFB, San Angelo, Texas, set up the experimental flight under the direction of T. Ashenfelter. The original HV3K module (Sampler A) had the outlet door fastened in the "open" position and the inlet door in the "closed" position, simulating past operational conditions. The modified HV3K module (Sampler B) had both sampling doors in a closed position.

The complete system ascended to about $30 \mathrm{~km}$ whereupon the outlet door of Samplex $A$ was closed and the sampling modules descended by parachute. As the balloon ascended, the telemetry of flowmeter speed was monitored for both modules. Telemetry was received from Sampler A, Indicating very low flow while telemetry from Sampler B indicated zero flow. Upon recovery of the package, the on-board flowmeter recorder from Sampler A indicated a rotational speed of about 8 cycles per second (cps) to about $7 \mathrm{~km}$, this is equivalent to about 0.6 ambient 
cubic meter of air per minute (ACM/min) passing through the filter media (Wood, et al., 1965; Loysen, 1966). The rotational speed decreased to about $6 \mathrm{cps}$ at an altitude of $13 \mathrm{~km}$, equivalent to about $0.5 \mathrm{ACM} / \mathrm{min}$. Above $13 \mathrm{~km}$ the rotational speeds were very low and the recorder chart could not be read accurately. As will be shown, the highest concentrations of fission products in the atmosphere at about $30^{\circ} \mathrm{N}$ existed between 13 to $23 \mathrm{~km}$. If one assumes that the rotational speed of the flowmeter between $13-23 \mathrm{~km}$ was between 4 to $2 \mathrm{cps}$, for the experimental flight of December 12, 1970 a volume of air of about 11 to $6 \mathrm{ACM}$ is estimated to have passed through the filter paper in this altitude range. It will be shown that this volume of air is in fair agreement with the radioactivity results presented in Table 1 . The on-board flowmeter recorder for Sampler B indicated zero flow through the filter media.

Radioactivity Results from the Experimental Flight

The filter papers from Sampler A and B were subjected to radiochemical analysis to see if any contamination occurred during ascent. The Sr-89 and Sr-90 data (pCi/total paper) for the December 12, 1970 experimental flight are shown in Table 1. Sampler A, in which the outlet door was in an open position and in which the flowmeter recorder Indicated air flow through the filter media showed considerable Sr-89 activity on its filter paper whereas Sampler B, in which the sampling doors were in a closed position indicated the Sr-89 value to be below 
the 11mits of detection. The low $\mathrm{Sr}-90$ values found on both filter papers is considered to be background $5 r-90$ indigenous to the 8-squarefoot filter paper (Krey, 1971).

The concentration profile (picocuries per ambient cubic meters of air, pCi/ACM) of Sr-89 and $\mathrm{Sr}-90$ based on aircraft and balloon flights (Krey and Kleinman, 1971) to $27 \mathrm{~km}$ is shown in Figure 2. It is assumed that this profile which was based on observations between December 23, 1970 and February 24, 1971 prevailed over the balloon launch site of San Angelo, Texas on the day of the experimental flight, December 12, 1970. As is quite evident, the highest concentrations occurred from 13 to $23 \mathrm{~km}$. The $\mathrm{Sr}-89$ concentrations at and above 23 $\mathrm{km}$ were below the limits of detection whereas the $\mathrm{Sr}-90$ concentration at $27 \mathrm{~km}$ was $3 \times 10^{-4} \mathrm{pCi} / \mathrm{ACM}$ (beyond the limits of the graph), a factor of about 50 less than the concentration at $23 \mathrm{~km}$.

The HV3K diffuser opening has a diameter of about 0.3 meter and during ascent between 13 to $23 \mathrm{~km}$ this diffuser would sample a column of air of about 700 ambient cubic meters if there were no obstruction to free flow. Since the outlet door of the original HV3K sampler was In an open position during ascent, the main obstructions to free flow would be the filter media and the inlet door. If the inlet door was partially open, one would then expect a small fraction of this air column to pass through the filter media.

The average concentration of $\mathrm{Sr}-89$ and $\mathrm{Sr}-90$ between $13-23 \mathrm{~km}$ based on the concentration profiles found in Figure 2 are shown in 
Table 1. Also given in Table 1 is the ambient cubic meters of air (ACM) required to pass through the filter paper during ascent from 13 to $23 \mathrm{~km}$ to account for the activity found on the filter paper. As can be seen, a leakage of $4.2 \mathrm{ACM}$ of air would be needed to account for the Sr-89 value found on the filter paper of Sampler A. This volume of air is $0.6 \%$ of the volume of air swept out by the HV3K diffuser if there were not obstructions to free flow. The volume, computed from the flowmeter (11-6 ACM of air) mentioned earlier, is in fair agreement with the leakage (based on the Sr-89 activity) as are the leakage results found on previous experimental flights of the original HV3K reported by Ashenfelter and Telegadas (1970). The average concentration of $\mathrm{Sr}-90$ from 13 to $23 \mathrm{~km}$ from the profile in Figure 2 is $0.05 \mathrm{pCi} / \mathrm{ACM}$. A leakage of $4 \mathrm{ACM}$ of air would account for $0.2 \mathrm{pCi}$ of the $1.2 \mathrm{pCi} /$ total filter paper found. This relatively sma11 contamination is within the range of Sr-90 contamination found on blank HV3K filter papers (Krey, 1971).

For Sampler B where both doors were in a closed position during ascent and descent and the flowmeter indicated zero flow through the sampling module, the Sr-89 activity found on the filter paper was below the limits of detection. Since the limit of detection is about $2 \mathrm{pCi} /$ total paper (Krey, 1971), if aix did pass through this system, it would have to be at most about $1 \mathrm{ACM}$ of air which is a factor of 4 less than assumed to have leaked through Sampler A.

It would appear from this experimental flight that if any leakage occurred in the modifled sampler it is of no significance. 
Preliminary Results from Operational Flights of the Modified HV3K Samplex

The modified HV3K Sampler has been flown operationally at about $41 \mathrm{~km}$ over Mildura, Australia and San Angelo, Texas since its intercomparison with the original HV3K Sampler in December 1970. The preliminary radioactivity results of these two flights are shown in Tab1e 2. Strontium-89 was not detected in resolvable amounts on either flight. Over Mildura, balloon sampling at 24 and $27 \mathrm{~km}$ by a Direct Flow Sampler and at 33 and $36 \mathrm{~km}$ by an Air Ejector Sampler in MarchApril 1971 indicated Sr-89 concentrations to be below the limits of detection (Krey and Kleinman, 1971). Afrcraft and balloon data indicated a layer of relatively high concentrations between 10 to $21 \mathrm{~km}$ during March 1971. It would appear that the modified HV3K sampler which sampled 25 standard cubic meters of air (SCH) at $41 \mathrm{~km}$ did not leak while ascending to the sampling altitude. The Sr-90 activity found on the Mildura flight can be compared with the activity found on 8 square feet of blank filter paper. Results indicate the $5 r-90$ activity to be within the background contamination level of the filter media.

Balloon flights over San Angelo, Texas between 27 to $37 \mathrm{~km}$ in May-June 1971 indicate $\mathrm{Zr}-95$ concentrations to be below the limits of detection (no Sr-89 data available at this time). Afrcraft data are not avallable to estimate the layer of highest concentrations. From the balloon data below the sampling altitude of the modified HV3K sampler, it appears that the modified sampler did not leak as it 
ascended to $41 \mathrm{~km}$. The $\mathrm{Sr}-90$ activity found on the June 1, 1971 flight also appears to be within the limits of the background contamination of the filter media.

Summary

The integrity of the original HV3K sampler used in collection of radioactivity samples at $41 \mathrm{~km}$ was questioned. It was demonstrated that during ascent, air may be forced down the diffuser tube, through the filter paper and out the inlet door, if the inlet door was partially open (Ashenfelter and Telegadas, 1970). A modification to the sampling doors has been developed by the Air Resources Laboratories, NOAA. This modification together with a modification of the sampling module (pressure relief port) to insure a contamination-free system has been flight tested against an original HV3K sampler. Results from this test, together with operational flight results, indicate that the filter media of the modified HV3K sampler does not appear to become contaminated by radioactive debris during its ascent to sampling altitude.

\section{Acknowledgment}

The authors gratefully acknowledge Philip W. Krey, Environmental Studies Division, Health and Safety Laboratory, USAEC for not only providing the radiochemical data but also the many helpful discussions concerning the contamination problem. Special thanks are due Robert $\mathrm{W}$. Beadle and Lt. Col. Thomas J. Gross, USAF, Fallout Studies Branch, 
Division of Biology and Medicine, USAEC for their valuable discussions covering all phases of the intercomparison tests and modification of the sampler.

This work was sponsored by the Division of Biology and Medicine, U.S. Atomic Energy Commission. 


\section{References}

Ashenfelter, T.E., and K. Telegadas, High-Volume-3000 Air Ejector

Sampler Contamination, USAEC Report HASL-227, I-10-I-24, July 1970.

Krey, P.W., Personal Communication, November 4, 1971.

Krey, P.W. and M.T. Kleinman, High Altitude Balloon Sampling Program, USAEC Report HASL-227, II-16-II-27, Ju1y 1970.

Krey, P.W., and M.T. Kleinman, High Altitude Balloon Sampling Program, USAEC Report HASL-245, II-37-II-93, October 1971.

Loysen, P., Air Sampling by Ascending and Descending Direct Flow Samples, USAEC Report 172, I-23-I-42, July 1966.

Wood, R.W., L.R. Graf and L. V. Nelson, Development and Calibration of the PR-3 Flowmeter, C00-401-118, Prepared for Division of Blology and Medicine, USAEC by Applied Science Division, Litton Industries, Minneapolis, Minn., August 1965. 
Tab1e 1. HV3K Comparison Test of December 12, 1970 (A11 data decay corrected to Dec. 12, 1970)

\begin{tabular}{|c|c|c|c|c|c|c|}
\hline \multirow[b]{3}{*}{ Sampler } & \multirow[b]{2}{*}{$S r-89$} & \multirow[b]{2}{*}{$\mathrm{Sr}-90$} & \multicolumn{2}{|c|}{$13-23 \mathrm{~km}$} & \multicolumn{2}{|c|}{ Leakage Required } \\
\hline & & & $5 x-89$ & $S x-90$ & $\mathrm{Sr}-89$ & Sr -89 \\
\hline & (pCi/total & paper) & $(\mathrm{pCi}$ & $(A C M)$ & $(\mathrm{ACM})$ & $(\%)$ \\
\hline A (original) & 9.2 & 1.2 & 2.2 & 0.05 & 4.2 & 0.6 \\
\hline B (modified) & ND & 1.2 & 2.2 & 0.05 & - & - \\
\hline
\end{tabular}

pCi/total paper: Picocuries found on total paper by radiochemical analyses.

PCi/ACM: Picocuries per ambient cubic meter of air; average concentration between $13-23 \mathrm{~km}$ from fig. 2 .

Leakage $(\mathrm{ACM})=\frac{\mathrm{pCi} / \text { total paper }}{\mathrm{pCi} / \mathrm{ACM}}$

$\%=\frac{\text { Leakage }(\mathrm{ACM})}{700 \mathrm{ACM} \text { Swept out by diffuser }} \times 100$

ND: Isotope was not detected in resolvable amounts. 
Table 2. Radioactivity Data from Operational

Flights of the Modified HV3K Sampler

\begin{tabular}{|c|c|c|c|}
\hline $\begin{array}{l}\text { Alt } \\
(\mathrm{km})\end{array}$ & $\begin{array}{l}\text { Volume } \\
\text { Air Sampled } \\
\text { (SCM) }\end{array}$ & $\begin{array}{c}\mathrm{Sr}-89 \\
\mathrm{pCi} / \text { total } 1\end{array}$ & $\begin{array}{l}\mathrm{Sr}-90 \\
1 \text { paper }\end{array}$ \\
\hline $\begin{array}{l}\text { Mildura, Australia, } 34 \\
\text { March 18, } 1971\end{array}$ & 25 & ND & 0.8 \\
\hline $\begin{array}{l}\text { San Angelo, Texas, } 31^{\circ} \\
\text { June } 1,1971\end{array}$ & 29 & $\mathrm{ND}$ & 1.4 \\
\hline Blank (1) & -- & ND & 1.6 \\
\hline
\end{tabular}

(1) 8 square feet of Blank IPC-1478 filter paper

ND Isotope was not detected in resolvable amounts. 


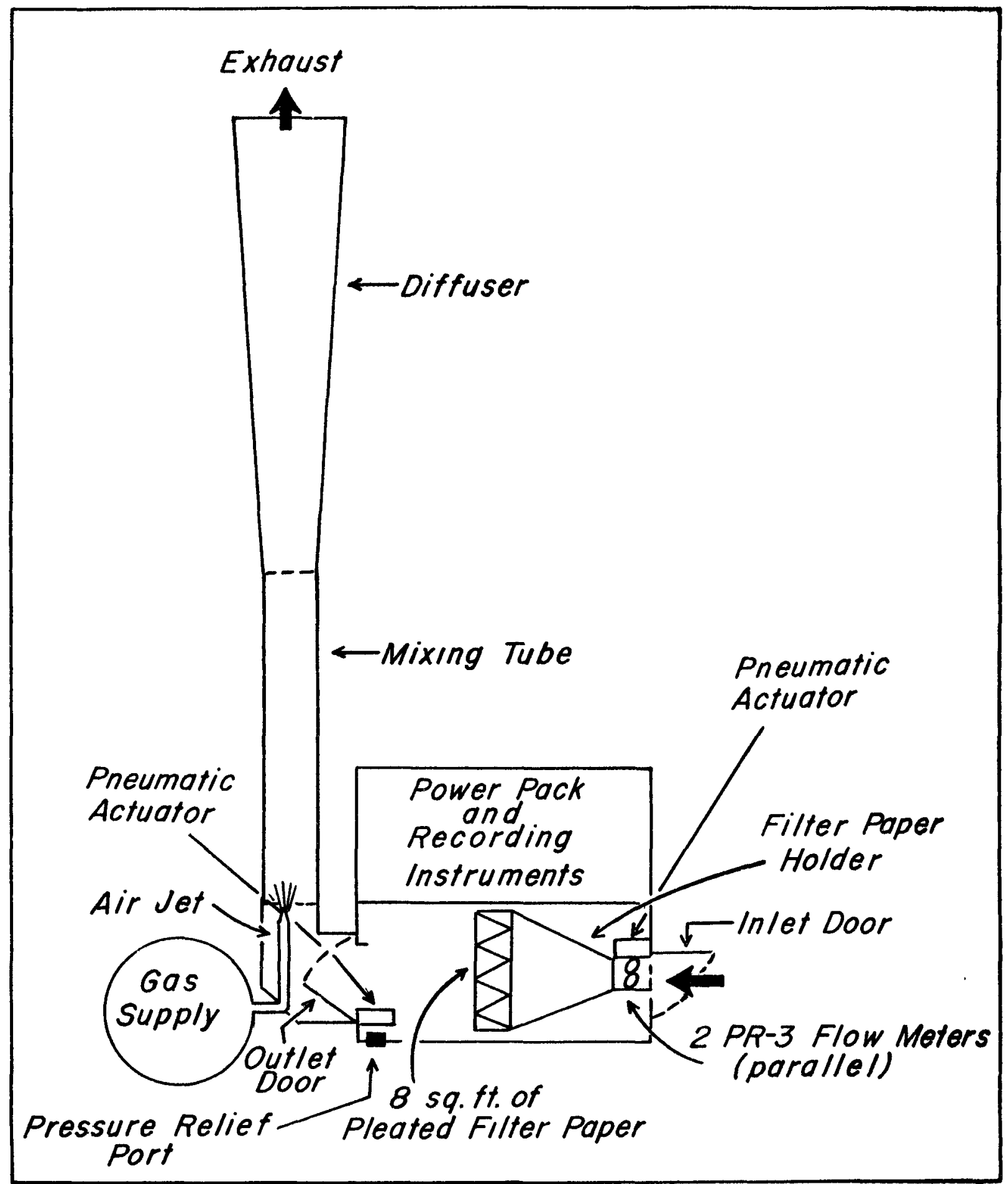

Fig.l: Schematic Diagram of Moditied HV3K Air Ejector Filter Sampler 


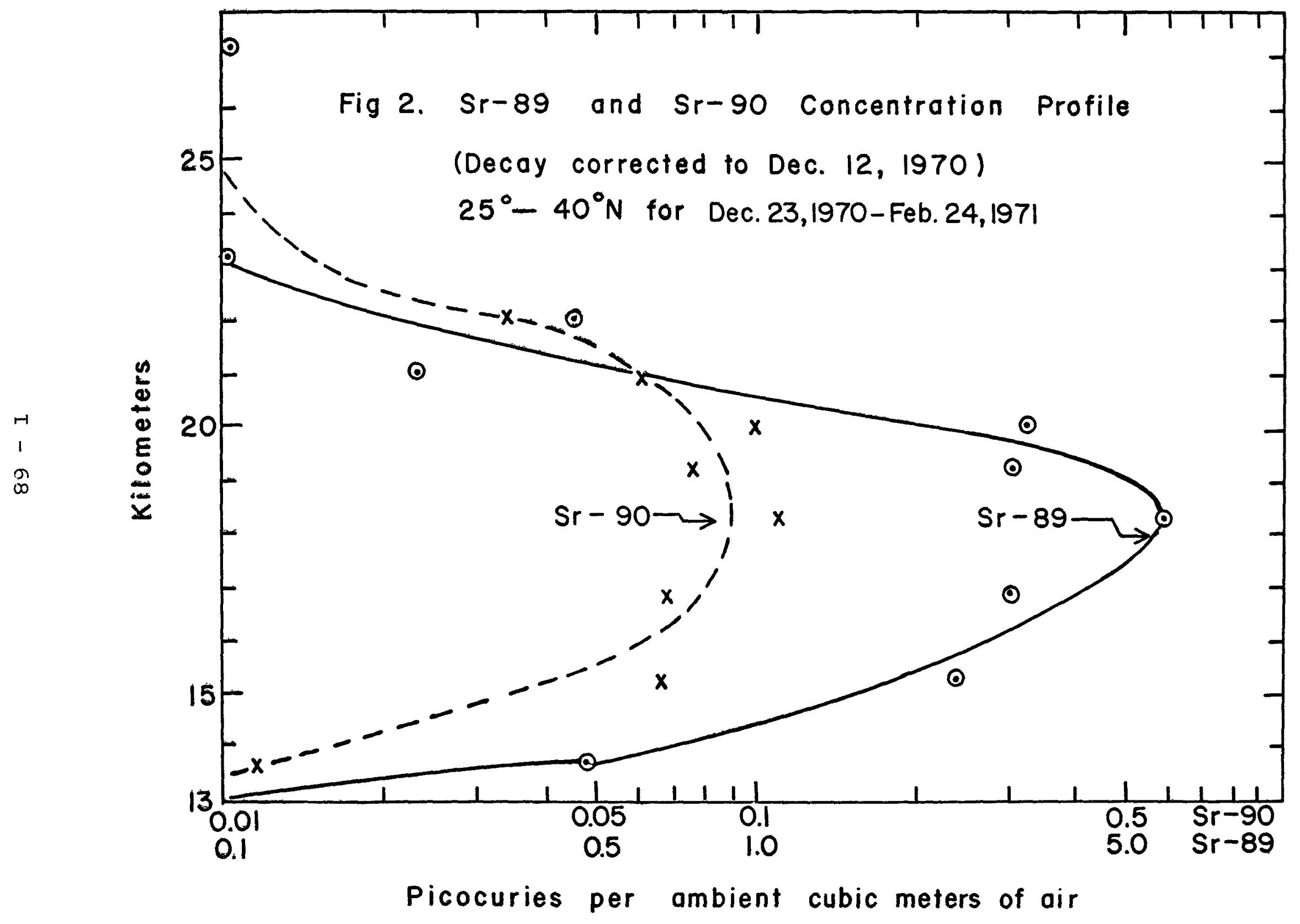


Carbon-14 Measurements in the Stratosphere

From a Balloon-Borne Molecular Sieve Sampler

K. Telegadas, (1) J. Gray, Jr, (2)

R.E. Sow $1^{(2)}$ and T.B. Ashenfe1ter ${ }^{(1)}$

\section{Abstract}

A new sampler for collection of atmospheric $\mathrm{CO}_{2}$ utilizing molecular sieve adsorption has been flown on operational USAEC balloon flights beginning in mid-1970 at four locations in the northern and two locations in the southern hemisphere at altitudes ranging from 21 to $37 \mathrm{~km}$. The $\mathrm{CO}_{2}$ collections were analyzed radiometrically for excess carbon-14 (C-14 due to nuclear weapons testing) and by mass spectrometric analysis for $\delta \mathrm{C}-13$ and $\delta_{0-18}$. Only the excess $\mathrm{C}-14$ and $\delta \mathrm{C}-13$ data are given. Although the $\delta_{0-18}$ data are not presented, a discussion of the results is given.

The $\delta_{\mathrm{C}-13}$ values decrease with altitude from 21 to $37 \mathrm{~km}$. This decrease is attributed to fractionation in the molecular sieve beds during the collection of $\mathrm{CO}_{2}$ rather than in nature or in the laboratory.

The excess C-14 data are presented in two latitudinal crosssections from which the stratospheric excess C-14 burden was determined.

(1) Air Resources Laboratories, NOAA, Silver Spring, Maryland 20910

(2) Argonne National Laboratory, Chemistry Division, Argonne, Illinois 60439 


\section{Carbon-14 Measurements in the Stratosphere \\ From a Balloon-Borne Molecular Sieve Sampler}

\section{Introduction}

The U. S. Government has conducted an extensive atmospheric program of whole air collection in the troposphere and stratosphere since 1953. These atmospheric samples were analyzed for C-14 collected in the form of $\mathrm{CO}_{2}$. Excess $\mathrm{C}-14$ ( $\mathrm{C}-14$ due to nuclear testing) data have been derived and the results made available (Hagemann, et a1., 1959, 1965; ESSA, 1966, 1967, 1969; NOAA, 1971). Recently, these data were used to determine the seasonal atmospheric distribution and inventories of excess C-14 from March 1955 to July 1969 (Telegadas, 1971a). The observed decreases of the excess C-14 inventory in the troposphere and stratosphere has been used by Machta (1971) to estimate the exchange of carbon dioxide between the atmosphere and the biosphere and oceans.

The high altitude balloon sampling portion (20 to $30 \mathrm{~km}$ ) of the whole air collection program terminated in July 1966 while the aircraft program, which sampled in the troposphere and lower stratosphere to $20 \mathrm{~km}$, continued until its termination in July 1969. The balloon portion of the C-14 program was operated for a year beginning in mid-1970 using a molecular sieve collector designed to replace the whole air balloon samplers. Plans are being discussed which may lead to a reestablishment of a somewhat modified version of the aircraft whole air sampling program supplemented by a continuation of the balloon molecular sieve sampler program. 
The molecular sieve sampler has been flown experimentally on the operational USAEC High Altitude Balloon Sampling Program (Krey and Kleinmann, 1971) on flight conducted over San Angelo, Texas $\left(31^{\circ} \mathrm{N}\right.$ ) at altitudes ranging from 21 to $37 \mathrm{~km}$. The experimental data which were collected from mid-1968 to early 1970 together with a description of the sampler and laboratory techniques for determining the excess C-14 specific activity have been reported by Ashenfelter, et a1., (1972).

For a year beginning in mid-1970, the molecular sieve samplers were flown operationally on the USAEC balloon flights at four locations in the northern hemisphere and two locations in the southern hemisphere. This paper repeats, where necessary, portions of the Ashenfelter, et al., (1972) report together with the data collected through mid-1971.

Future results of the $\mathrm{C}-14$ molecular sieve program will be published as they become available in the USAEC Health and Safety Quarterly Summary Reports.

\section{Description of the Carbon-14 Molecular Sieve Sampler}

The balloon-borne C-14 molecular sieve sampler which was designed to collect $\mathrm{CO}_{2}$ at altitudes ranging from 20 to $37 \mathrm{~km}$ is shown in figure 1. The complete system, containing Linde Type $4 \mathrm{~A}$ molecular sieve (1/8 inch diameter adsorbent pellets), helium primary gas supply and necessary hardware, weighs about $30 \mathrm{~kg}$. The air ejector principle is used to move ambient air at a known flow rate through the two collection beds. 
The C-14 sampler was tested in the High Altitude Test Chamber of the USAEC Health and Safety Laboratory in New York City to determine the proper aix ejector design and operating parameters to insure that a sufficient volume of $\mathrm{CO}_{2}$ would be collected with approximately $100 \%$ efficiency at selected altitudes. Experimental flights over San Angelo, Texas, were conducted from mid-1968 to mid-1970 to verify the chamber results (Ashenfelter, et a1., 1972).

\section{Sampling Locations}

The new $\mathrm{C}-14$ sampler can readily be flown on the USAEC balloonborne particulate sampling missions. Both samplers (molecular sieve and particulate sampler) were normally flown together at altitudes of 21,24 , 27,32 , and $37 \mathrm{~km}$ at the following locations:

\section{Location}

Eielson Air Force Base, Alaska

Sioux City, Iowa

San Ange1o, Texas

Albrook Air Force Base, Panama Canal Zone

Longreach Queensland, Australia

Mildura, Australia
Latitude

$65^{\circ} \mathrm{N}$

$42^{\circ} \mathrm{N}$

$31^{\circ} \mathrm{N}$

$9^{\circ} \mathrm{N}$

$23^{\circ} \mathrm{S}$

$34^{\circ} \mathrm{S}$

The complete sampling system is lifted to a pre-determined float altitude where sampling begins for a pre-determined time. Upon completion of sampling, the system descends by parachute and is recovered. 
The molecular sieve adsorbents are returned to Argonne National Laboratory (ANL) for quantitative determination of adsorbed $\mathrm{CO}_{2}$ and for $\mathrm{C}-14$, C-13 and 0-18 analyses.

IV. Determination of Excess Carbon-14

The techniques for separating $\mathrm{CO}_{2}$ from the molecular sieve pellets and the C-14 counting techniques are given by Ashenfelter, et a1. (1972). In addition, a small aliquot of $\mathrm{CO}_{2}$ is routinely taken for $\mathrm{C}-13$ and $0-18$ mass spectrometric analysis.

In the determination of excess $\mathrm{C}-14$, a known quantity of purified $\mathrm{CO}_{2}$ is transferred into one of six 2-liter low-background counters. The data from these counters are reported in "absolute" disentegrations per minute per gram of carbon $(\mathrm{dpm} / \mathrm{gC})$. The technique employed by carbon dating laboratories is to avoid absolute calibration by taken the ratio of the unknown sample to a National Bureau of Standard (NBS) oxalic acid C-14 standard converted to $\mathrm{CO}_{2}$. The actual value of pre-bomb $\mathrm{CO}_{2}$ (modern wood) is considexed to be equal to 0.95 NBS oxalic acid standard or $13.1 \mathrm{dpm} / \mathrm{gC}$.

The "absolute" activity of the ANL standard gas (2000 dpm/1) has been used to calibrate all counters and the NBS oxalic acid standard. The ANL counters gave a mean value for 0.95 oxalic acid standard of 13.17 $\pm 0.04 \mathrm{dpm} / \mathrm{gC}$ at the 2-sigma confidence level. Thus, ANL confirms within experimental error the generally accepted value of $13.1 \mathrm{dpm} / \mathrm{gC}$ for the oxalic acid standard. 
The numbers reported in this paper as excess specific activity (Table 1) are the measured $\mathrm{dpm} / \mathrm{gC}$ minus $13.1 \mathrm{dpm} / \mathrm{gC}$. In relating excess activity to bomb $\mathrm{C}-14$ concentrations (atoms per gram of air) we have used $74 \times 10^{5}$ atoms/g of air as the pre-bomb background (Hagemann, et al., 1965) assuming a $\mathrm{CO}_{2}$ concentration in air of $313 \mathrm{ppm}$ (by volume).

\section{Stratospheric Carbon-14 Measurements}

The experimental and operational data using the molecular sieve sampler are given in Table 1. An explanation of the table is given:

Column 1. Flight No.

The experimental flights conducted over San Angelo, Texas are designated by an $\mathrm{X}$.

Column 2. Date

The date of collection is given by three two digit groups of month, day and year.

Column 3. Alt.

The mean pressure altitude of the collection is given in kilometers.

Column 4. Bed No.

The data from the two sampling beds are listed as Bed 1 (the primary sampling bed) and Bed 2 (the back-up bed to detect any breakthrough of $\mathrm{CO}_{2}$ from Bed 1 ).

Column 5. Vol. $\mathrm{CO}_{2} \cdot$

The volume of $\mathrm{CO}_{2}$ in cubic centimeters (cc) collected at STP on each bed. 
column 6. $\delta \mathrm{c}-13$

The measured $\mathrm{C}-13 / \mathrm{C}-12$ value expressed as the deviation from Craig's (1957) limestone standard in units of per mil $(0 / 00)$.

$$
\delta_{c-13}=\left[\frac{c-13 / c-12(\text { Sample) }}{c-13 / c-12 \text { (P.D.B. Standard) }}-1\right] \times 1000
$$

The standard error of the determination is estimated at $0.2 \%$.

Column 7. Excess Spec. Act.

These numbers are the observed specific activity (dpm/gC) minus $13.1 \mathrm{dpm} / \mathrm{gC}$. This is therefore the excess specific activity due to nuclear weapons testing.

The counting exror of the observed specific activity at the $95 \%$ confidence level is less than $5 \%$ in all samples and less than $3 \%$ in $90 \%$ of the samples.

Column 8. C-14 Excess.

These numbers are the excess specific activity (dpm/gC) converted to $\mathrm{C}-14$ excess concentration in units of $10^{5}$ atoms per gram of air.

C-14 Excess $=$ Excess Spec. Act. $(\mathrm{dpm} / \mathrm{gC})]\left[\frac{74 \times 10^{5} \text { atoms } / g \text { air }}{13.1 \mathrm{dpm} / \mathrm{gC}}\right]$

Column 9. C-14 Excess, Wt. Avg.

These values are the weighted average of the excess $c-14$ determination from Bed 1 and 2 weighted by the volume of 
$\mathrm{CO}_{2}$ collected on each bed and is defined as:

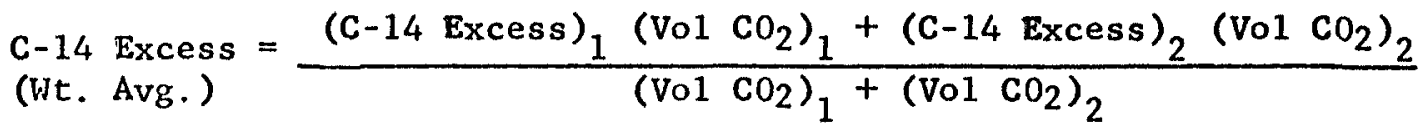

Column 10. Remarks

The meaning of each remark is given at the bottom of each page of Table 1 .

vI. Distribution of $\delta \mathrm{C}-13$ with A1titude

As mentioned previously, aliquots of $\mathrm{CO}_{2}$ are taken for the measurement of the C-13/C-12 ratio. Knowing this ratio, a correction can be applied to the $\mathrm{C}-14$ counting rate to correct for any fractionation, relative to a standard, of the carbon isotopes (Broecker and 01son, 1961). This fractionation may have taken place in nature, during collection of $\mathrm{CO}_{2}$ or in the laboratory.

The $\delta \mathrm{C}-13$ of uncontaminated air is assumed to be $-7.10 / 00$ as suggested by Craig (1953) and Keeling (1961) from ground level air. About 100 whole air samples collected over San Angelo, Texas $\left(31^{\circ} \mathrm{N}\right)$ between 20 and $33 \mathrm{~km}$ from January 1964 to May 1966 had an average $\mathrm{CO}_{2}$ concentration of $308 \pm 5$ ppm by volume (Hagemann, et a1., 1965; ESSA, 1966, 1967, 1969). These samples were analyzed by ANL and yielded an average $\delta_{\mathrm{C}-13}$ value of $-8.10 / 00$ with a standard deviation about the mean of 1.0. The average $\delta_{\mathrm{C}-13}$ value, $-8.10 / 00$, is in agreement with the $-7.10 / 00$ reported by Craig and Keeling.

Young (1967, 1971) used Linde type 4A molecular sieve for the adsorption of $\mathrm{CO}_{2}$ from the air at ground level and at aircraft 
altitudes. Aliquots of uncontaminated $\mathrm{CO}_{2}$ from 25 atmospheric samples yielded an average $\delta \mathrm{C}-13$ of $-9.20 / 00$ with a range of $-10.30 / 00$ to $-7.70 / 00$. The average $\delta_{\mathrm{C}-13}$ and its standard deviation was determined for the molecular sieve data listed in Table 1. The results are shown in Table 2 for Bed 1 (Primary), Bed 2 (Breakthrough) and the weighted average for both beds (weighted by $\mathrm{CO}_{2}$ collected) together with the results from the whole air collections mentioned previously. The results indicate that the scatter about the mean value for the molecular sieve $\delta_{\mathrm{C}-13}$ data (Bed 1 and 2 are weighted for $\mathrm{CO}_{2}$ content) is greater than that of the whole air collector. The $\delta c-13$ mean value for Bed 1 (where, in nearly all cases, most of the $\mathrm{CO}_{2}$ was adsorbed) is in agreement with the mean value of the whole air collector. Table 2 shows a significant difference between the average $\delta_{C-13}$ value of Bed 1 and Bed 2 indicating an enrichment of $\mathrm{C}-13$ molecules in Bed 2 relative to Bed 1 .

In exploring the fractionation effect further, the $\delta_{\mathrm{C}-13}$ values determined from both the molecular sieve and whole air collectors were plotted as a function of collection altitude. This distribution is shown in figure 2 for Bed 1 and Bed 2 while the weighted average of Bed 1 and Bed 2 together with the whole air collector are shown in figure 3 . The equation for the "line of best fit" together with the standard deviation about that line is shown on both figures. A statistical analysis indicates that the level of significance is 0.02 for Bed 1 and 0.01 for Bed 2 signifying the decrease of $\delta \mathrm{c}-13$ with altitude did not happen by chance. A11 individual stations showed about the same trend of $\int_{C-13}$ 
with altitude evident in the mean pictures of figures 2 and 3.

The $\delta$ C-13 data from the whole air collector (figure 3 ) were determined by ANL. Since this distribution does not show any altitude dependency in the $\delta \mathrm{c}-13$ results, it is apparent that fractionation in the molecular sieve system (also analyzed by ANL) took place during the collection of $\mathrm{CO}_{2}$ and had not taken place in nature or in the 1aboratory.

To explore this isotopic fractionation with altitude, laboratory experiments are being conducted to simulate altitude, bed temperature and flow rates as well as an examination of these parameters from the actual flight records to see if an explanation can be found.

VII. Stratospheric Distribution of $\delta_{0-18}$

Aliquots of $\mathrm{CO}_{2}$ adsorbed by the molecular sieve material were also taken for the measurement of the oxygen isotopic composition of atmospheric $\mathrm{CO}_{2}$. The definition of $\delta 0-18$ (Hagemann, et al., 1965) is analogous to that for $\delta \mathrm{c}-13$ :

$$
\delta 0-18=\left[\begin{array}{ll}
0-18 / 0-16 \text { (Sample }) \\
0-18 / 0-16 \text { (P.D.B. Standard })
\end{array}-1\right] \times 1000
$$

Craig and Begemann (1970) using the $\delta 0-18$ data reported by Hagemann, et al. (1965) for the period 1953-1964 indicated the average stratospheric value to be $-5.00 / 00$. They showed that collected data from the whole air sampler,

". . do not reflect the actual isotopic composition of

oxygen in $\mathrm{CO}_{2}$ but rather an artifact of the sampling technique." 
We have calculated the mean $\delta_{0-18}$ and standard deviation about the mean for the whole air samples collected between 20 to $33 \mathrm{~km}$ over San Ange1o, Texas $\left(31^{\circ} \mathrm{N}\right)$ between January 1964 to May 1966. (Hagemann, et al., 1965; ESSA 1966, 1967, 1969). An average value of $-4.9 \pm 5.2$ $0 / 00$ was determined which was not dependent on altitude. This is in agreement with the value, $-5.00 / 00$ reported by Craig and Begemann. The $\delta$ 0-18 determined from the molecular sieve samples collected between 20 to $37 \mathrm{~km}$ had a mean and standard deviation of $-18.1 \pm 4.10 / 00$, and was also found to be independent of collection altitude.

During a recent meeting held on August 24, 1971 at ANL to discuss the collection of atmospheric gases using molecular sieve material, H. Gote Ostlund stated that,

". . there was oxygen isotopic exchange in both influent $\mathrm{H}_{2} \mathrm{O}$ and $\mathrm{CO}_{2}$ with the $\mathrm{SiO}_{2}$ and/or residual water in the sieve so that isotopic oxygen analysis with molecular sleves is "impossible" (Krey 1971).

Even though the $\delta 0-18$ of atmospheric $\mathrm{CO}_{2}$ desorbed from the molecular sieve material was determined, it is not reported here due to the findings of Craig and Begemann (1970) and the statement by Ostlund (Krey 1971). They are however available from the authors.

\section{Latitudinal Distribution of Stratospheric Excess C-14}

The data listed in Table 1 permits a reasonable inventory of the excess $\mathrm{C}-14$ in the stratosphere above $20 \mathrm{~km}$ and $i t s$ distribution for the first time since early 1959 when four balloon stations were in 
operation (Telegadas, 1971). After 1959, only one balloon station was used in the collection of whole air samples (San Angelo, Texas, $31^{\circ} \mathrm{N}$ ) and this station terminated in July 1966. The latitudinal distribution of excess C-14 as a function of altitude for two periods, September December 1970 and January - June 1971, are shown in figures 4 and 5 . The northern and southern hemisphere excess $C-14$ burden between 21 and 37 $\mathrm{km}$ (Table 3) was estimated using the distribution in these figures.

Telegadas (1971) computed the stratospheric burden of excess C-14 in the northern and southern hemispheres between 21 and $31 \mathrm{~km}$ from similar cross sections from June 1964 to July 1966 with only one sampling location. The effective half residence time of excess $\mathrm{C}-14$ for the whole hemispheric compartment from 21 to $31 \mathrm{~km}$ is estimated to be about 60 months. Extrapolating the mid-1964 to mid-1966 excess C-14 inventory with a 60-month half residence time, assuming no new inputs into this compartment by large yield nuclear tests, one finds an estimated inventory for the same periods as given in figures 4 and 5 of 16 and $15 \times 10^{26}$ excess C-14 atoms. These extrapolations are listed in Table 3 where they can be shown to be $40 \%$ less than the observed inventories. If this comparison is valid, about $40 \%$ of the high altitude excess $\mathrm{C}-14$ can be attributed to the Chinese and French high yield tests conducted between mid-1967 to mid-1970. This conclusion must be tempered by the large uncertainty in the inventories between mid-1964 to mid-1966 since they are based on a limtted number of samples at only one location. 
An examination of the data analyzed from the USAEC particulate samplers flown on the same balloon with the molecular sieve sampler reveals that the short-1ived fission product $\mathrm{Zr}-95$ (65 day half-1ife) and the long-1ived $\mathrm{Cs}-137$ (30 year half-1ife) in balloon samples collected above $20 \mathrm{~km}$ are one to two orders of magnitude less than samples collected at and below $21 \mathrm{~km}$ by balloons and aircraft. Based on fission product considerations, it is tempting to speculate that virtually no gaseous $\mathrm{C}-14$ was injected above $21 \mathrm{~km}$ and the maximum concentrations of excess $\mathrm{C}-14$ observed at about $25 \mathrm{~km}$ in both hemispheres (figures 4 and 5) are due possibly to the nuclear tests conducted by the USSR and U.S. in 1961-1962.

Important information about the motions of the atmosphere can be obtained from the investigation of the distribution of radioactive substances in the atmosphere and their changes in time. Unique tracers such as W-185, Rh-102, Cd-109, Pu-238 (Franke1 and Salter, 1961; Telegadas, 1971b; Telegadas and List, 1964; 1969) and the activity ratios of fission products from nuclear tests (Feely and Spar, 1960; Gudiksen, et al., 1968; Kalkstein, 1962; List and Telegadas, 1969; Machta, et al., 1970) have proven very useful in yielding information on the transport and diffusion processes within the stratosphere. Before any interpretation of a distribution is attempted, one should try to determine where and when the tracer material started from.

The latitudinal distribution of excess C-14 in figures 4 and 5 indicate maximum concentrations in temperate and polar latitudes of 
both hemispheres at about $25 \mathrm{~km}$ and a minimum concentration over the equatorial region. This pattern may be compared with fission product distributions of $\mathrm{Zr}-95$ and $\mathrm{Cs}-137$ based on aircraft data to about $20 \mathrm{~km}$ and balloon data above for November 1970 and February 1971 as given by Krey and Krajewski (1971). The maximum concentrations of these fission products in the northern hemisphere temperate and polar regions lie between 14 to $18 \mathrm{~km}$ and are attributed primarily to the Chinese high yield nuclear test conducted at $40^{\circ} \mathrm{N}$ in October 1970 . The southern hemisphere maximum is found between $15-19 \mathrm{~km}$ in the equatorial and temperate latitude region (no sampling beyond $50^{\circ} \mathrm{S}$ ) and is ascribed to the two high yield French nuclear tests conducted at $22^{\circ} \mathrm{S}$ between May to August 1970. The maximum concentration in both hemispheres in general slope along surfaces oriented downward toward the poles. It is significant that the fission-product maximum is 5 to $10 \mathrm{~km}$ lower in altitude than the excess C-14 distributions shown in figures 4 and 5 . Telegadas and List (1969) have shown that particle settling of radioactive debris to be insignificant after a few weeks or so of a nuclear test. It therefore seems unreasonable that the fission product maximum concentrations would be this much lower than the excess C-14 maximum concentrations if they were from the same events. It would appear that the maximum concentrations of excess $\mathrm{C}-14$ observed at about $25 \mathrm{~km}$ in both hemispheres, figures 4 and 5, are due primarily to the high yield nuclear tests conducted prior to the Chinese and French high yield nuclear tests of 1967-1970. 
It is difficult to interpret the observed distributions of excess C-14 shown in figures 4 and 5 in terms of atmospheric processes due to the uncertainties as to the source of excess $\mathrm{C}-14$. A reactivation of the aircraft whole air sampling program and a continuation of the collection of $\mathrm{CO}_{2}$ balloon samples would prove valuable in the investigation and refinement of the exchange rates of $\mathrm{CO}_{2}$ between the atmosphere and the biosphere and oceans as has been recently reported by Machta (1971).

\section{Acknowledgements}

We are indebted to Laura D. Studebaker of ANL in processing the high-altitude balloon samples and to Miss Y. Causey, NOAA, for the compilation of the data in Table 1. We wish to acknowledge the assistance of Antoinette G. Engelkmeir for mass spectrometric measurements of $\delta \mathrm{c}-13$ and $\delta_{0-18}$; and also that of G. Cotton, NOAA, for the statistical analysis and helpful discussions of the $\mathrm{Sc}-13$ data.

Special thanks are due to Detachment 31 , 6th Weather Wing (MAC), Goodfellow Air Force Base, San Angelo, Texas and the Balloon Launching Station, Department of Supply, Mildura, Victoria, Australia for their efficient performance in the preparation, launching and recovery of the balloon samples.

The support of this work by the Division of Biology and Medicine and the Division of Research of the USAEC is gratefully acknowledged. 


\section{References}

Ashenfelter, T.E., J. Gray, Jr., R.E. Sow1, M. Svendsen and K. Telegadas, A Lightweight Molecular Sieve Sampler for Measuring Stratospheric Carbon-14, J. Geophys. Res., 77(3), 1972.

Broecker, W.S. and E.A. Olson, Lamont Radiocarbon Measurements VIII, Radiocarbon, 3, 176-204, 1961.

Craig, H., The Geochemistry of the Stable Carbon Isotopes, Geochem. et Cosmoch. Acta, 3, 53-92, 1953.

Craig, H., Isotopic Standards for Carbon and Oxygen Correction Factor for Mass Spectrometric Analysis of Carbon Dioxide, Geochem. et Cosmoch. Acta, 12, 133-149, 1957.

Craig, H. and F. Begemann, Oxygen-18 Variations in Atmospheric Carbon Dioxide: The HASL Data, J. Geophys. Res., 75 (9), 1723-1726, 1970.

Environmental Science Services Administration, Carbon-14 Measurements in the Atmosphere, HASL-166, January 1966.

, Carbon-14 Measurements in the Atmosphere, HASL-174, January 1967.

, Carbon-14 Measurements in the Atmosphere, HASL-214, October 1969.

Feely, H.W., and J. Spar, Tungsten-185 from Nuclear Bomb Tests as a Tracer for Stratospheric Meteorology, Nature, 188, 1062-1064, 1960.

Franke1, R., and L.P. Salter, On the Cerium-144/Strontium 90 Ratio in Precipitation, HASL-115, 1961.

Gudiksen, P.H., A.W. Fairhall and R.J. Reed, Role of Mean Meridional Circulation and Eddy Diffusion in the Transport of Trace Substances in the Lower Stratosphere, J. Geophys. Res.. 73, 4461-4474, 1968.

Hagemann, F., J. Gray, Jr., and L. Machta, Carbon-14 Measurements in the Atmosphere 1953 to 1964, HASL-159, April 1965.

Kalkstein, M.J., Rhodium-102 High Altitude Tracer Equipment, 1. Stratospheric Results, U.S. Air Force Publ. AFCRL-62-460, 1962.

Keeling, C.D., A Mechanism for Cyclic Enrichment of Carbon-14 by Terrestrial Plants, Geochem. et Cosmoch. Acta. 24, 299-313, 1961 . 
Krey, P.W., Summary of the Molecular Sieve Meeting held at Argonne Nationa1 Laboratory, August 24, 1971 (Unpublished).

Krey, P.W. and M.T. Klelnman, High Altitude Balloon Sampling Program, HASL-245, October 1971 .

Krey, P.W., and B.T. Krajewski, Updating Stratospheric Inventories to February 1971, HASL-245, 1971.

List, R.J. and K. Telegadas, Using Radioactive Tracers to Develop a Model of Circulation of the Stratosphere, J. Atmos. Sc1.2.26, 1128-1136, 1969.

Machta, L., The Role of the Oceans and Biosphere in the Carbon Dioxide Cycle, Nobel Symposium 20, Gothenburg, Sweden, August 1971 (to be published).

Machta, L., K. Telegadas and R.J. List, The Slope of Surfaces of Maximum Tracer Concentration in the Lower Stratosphere, J. Geophys. Res., 75, 2279-2289, 1970.

National Oceanic and Atmospheric Administration, Carbon-14 Measurements in the Atmosphere, HASL-242, Apri1 1971.

Telegadas, K., The Seasonal Atmospheric Distribution and Inventories of Excess Carbon-14 from March 1955 to July 1969, HASL-243, 1971 a.

Telegadas, K., The Upper Portion of the Hadley Cell Circulation as Deduced from the 1968 French and Chinese Nuclear Tests, J. Geophys, Res.. 76, 5018-5024, 1971b.

Telegadas, K., and R.J. List, Global History of the 1958 Nuclear Debris and its Meteorological Implications, J, Geophys. Res.. 69, 4741$4753,1964$.

Telegadas, K., and R.J. List, Are Particulate Radioactive Tracers Indicative of Stratospheric Motions? J. Geophys. Res. . 74, 1339$1350,1969$.

Young, J.A., Radiocarbon from Nuclear Weapons Tests and its Use as a Geophysical Tracer, PHD Thesis, University of Washington, Dept. of Chemistry, 1967.

Young, J.A., Private communication, 1971. 
EIELSON AFB, ALASKA $65 \mathrm{~N}$

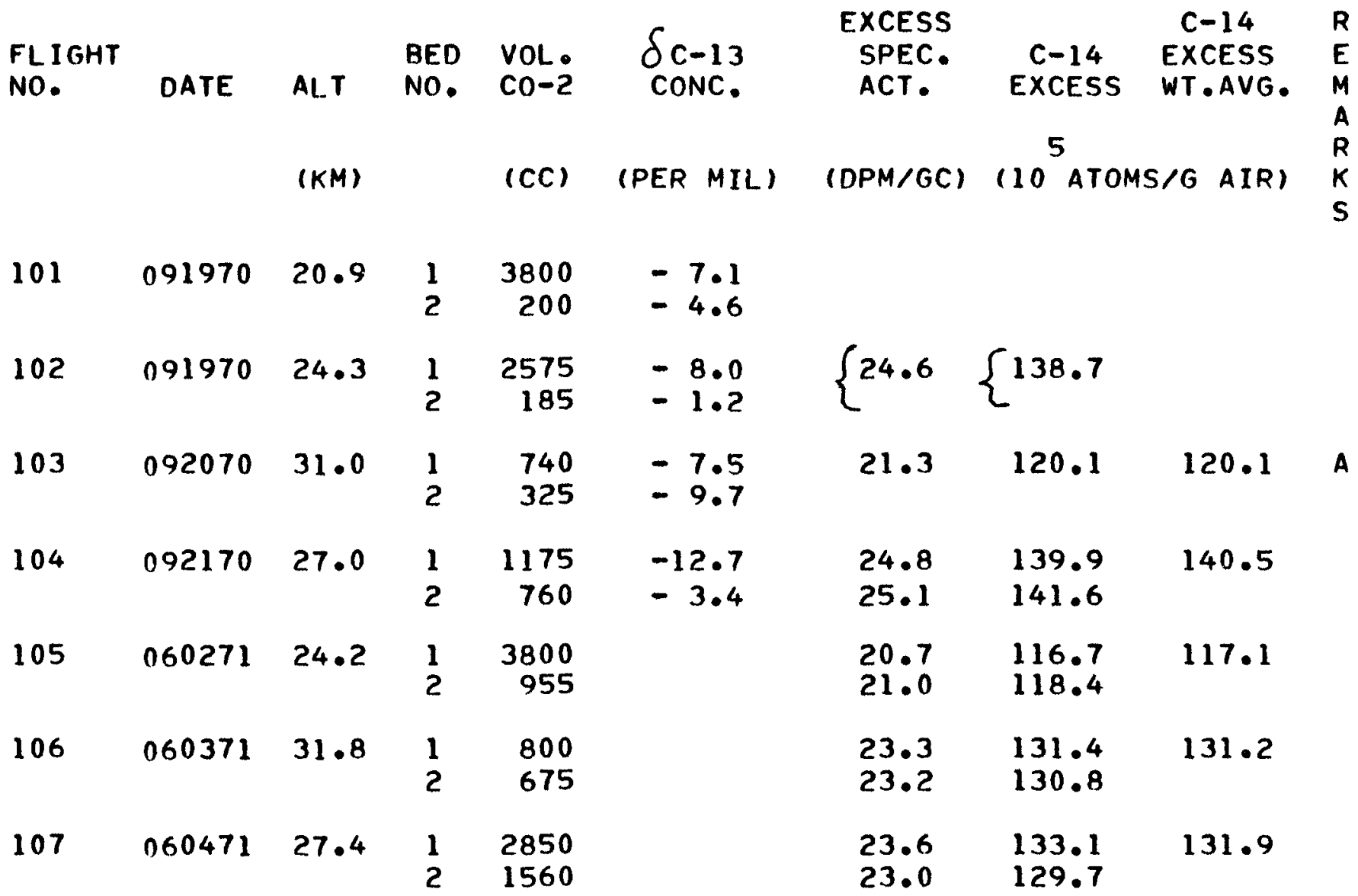


TABLE 1

STRATOSPHERIC CARBON-14 MEASUREMENTS

SIOUX CITY, IOWA 42N

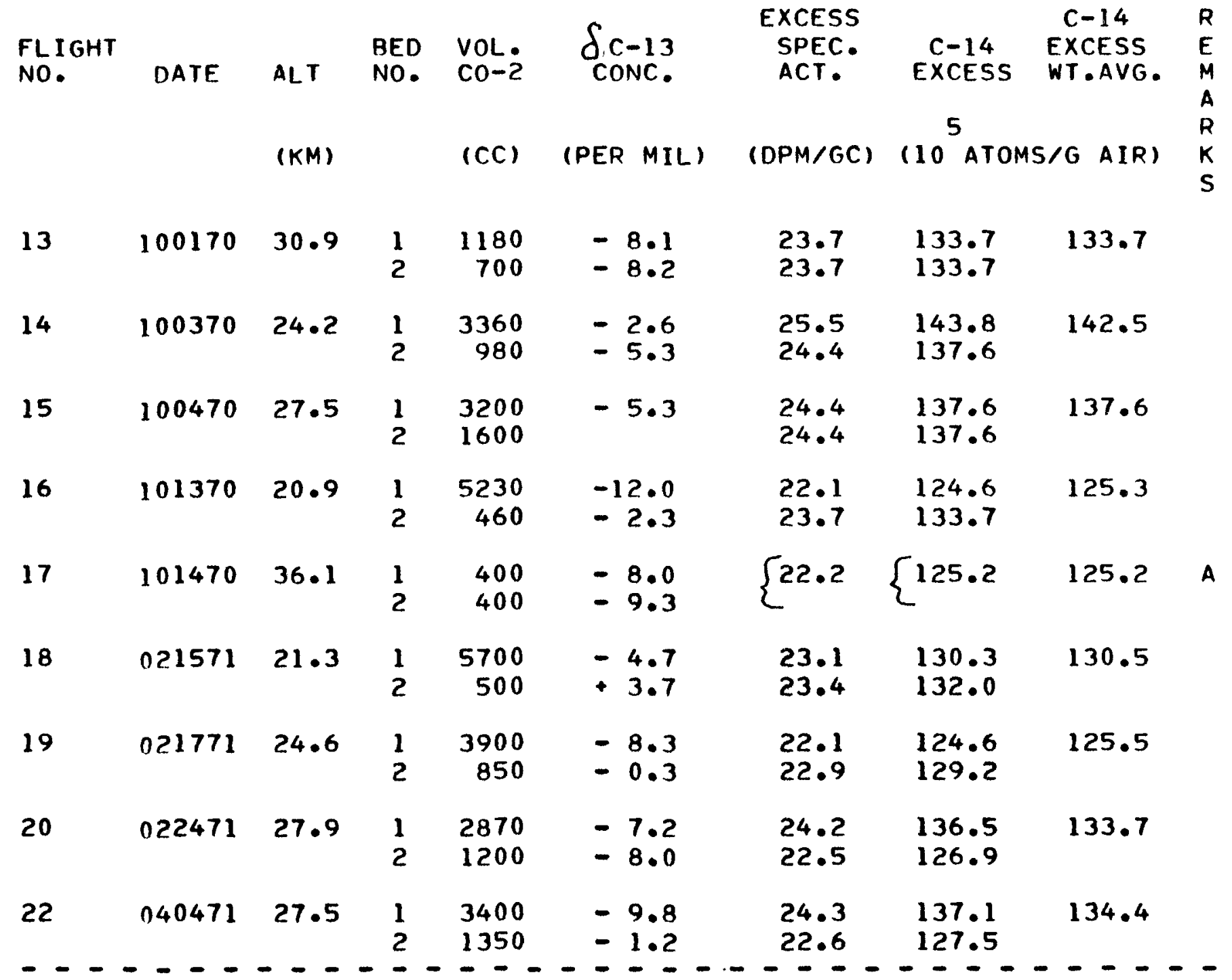

A. BFD 1 AND 2 COMBINED FOR SPECIFIC ACTIVITY ANALYSIS 
TABLE 1 STRATOSPHERIC CARBON-14 MEASUREMENTS

SIOUX CITY, IOWA 42N

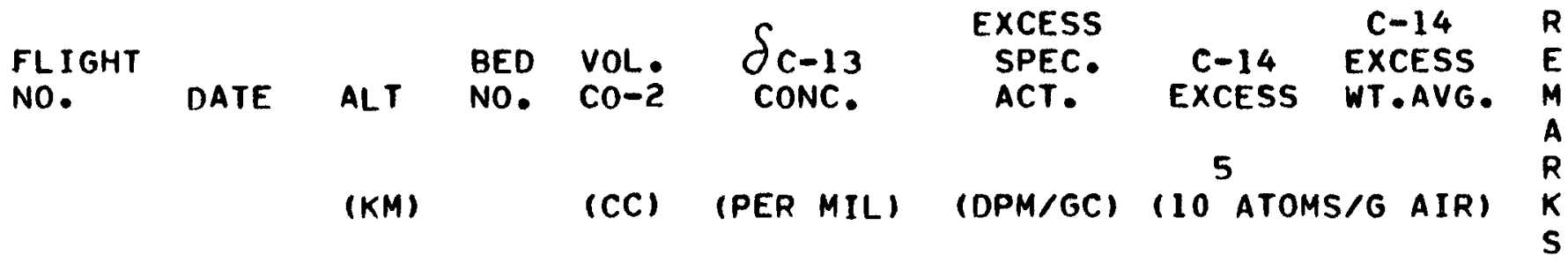

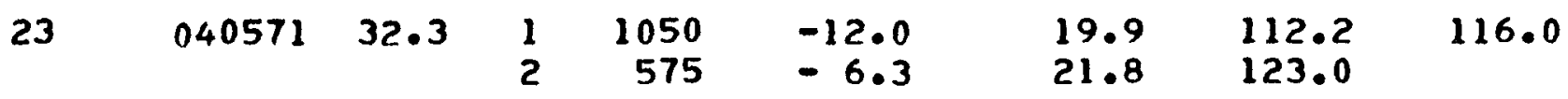

\begin{tabular}{lllllllll}
24 & 040671 & 24.7 & 1 & 3400 & -1.9 & 20.5 & 115.6 & \\
& & & 2 & 1200 & --1.9 & -120 & -1.9 & \\
25 & \multirow{2}{*}{040771} & 21.6 & 1 & 4700 & -9.1 & 21.9 & 123.5 & 122.9 \\
& & & 2 & 1075 & -1.2 & 21.4 & 120.7 &
\end{tabular}

A

A A. LOST IN PURIFICATION 
TABLE 1

STRATOSPHERIC CARBON-14 MEASUREMENTS

SAN ANGFLO, TEXAS 3IN

FLIGHT

$\begin{array}{llll} & \text { BED } & \text { VOL. } & \delta C-13 \\ \text { DATE ALT NO. } & \mathrm{CO}-2 & \text { CONC. }\end{array}$

EXCESS

SPEC.

C-14

$\mathrm{C}-14$

ACT.

EXCESS

EXCESS

R

NO.

$(K M)$

(CC) (PER MIL)

5

(DPM/GC) (10 ATOMS/G AIR)

R

$K$
$S$

$\begin{array}{llllllllll}1272 \times & 052468 & 36.6 & 1 & 407 & -12.2 & 28.0 & 157.9 & 155.6 \\ & & & 2 & 368 & -12.9 & 27.5 & 155.1 & \\ 1287 \times & 110568 & 36.3 & 1 & 326 & -12 . ? & 24.4 & 137.6 & 147.0 \\ & & & 2 & 247 & -4.5 & 28.3 & 159.6 & \\ 1293 \times & 012169 & 29.2 & 1 & 2804 & -14.1 & 27.5 & 155.1 & 154.9 \\ & & & & & & & & \\ 12 & 473 & -5.3 & 27.3 & 154.0 & \end{array}$

$\begin{array}{rrrrrr}1296 \times & 021169 & 29.8 & 1 & 977 & -14.7\end{array}$

$24.9 \quad 140.4$

A

$1301 \times \quad 031369 \quad 20.8$

$\begin{array}{rrr}1 & 4120 & -7.2 \\ 2 & 679 & -----\end{array}$

28.1

28.0

158.5

157.9

$158 \cdot 4$

28.0

27.5

157.9

155.1

$\begin{array}{lllll}1305 \times \quad 051369 & 36.4 & 1 & 1795\end{array}$

$2 \quad 2168$

$-4.0$

10.1

57.0

11.3

63.7

$157 \cdot 2$

$-6.3$

27.9

157.4

$26.1 \quad 147.2$

154.1

$1306 \times \quad 051869 \quad 32.8$

518

$-6.8$

$25.3 \quad 142.7 \quad 141.5$

$1309 \times \quad 070169 \quad 24.3 \quad 1 \quad 4765$

$-9.0$

$24 \cdot 2$

136.5

B

A. SPECIFIC ACTIVITY NOT COUNTED FOR BED 2

B. NO ANALYSIS OF $\delta \mathrm{C}-13$ FOR BED 2 
TABLE 1

STRATOSPHERIC CARBON-14 MEASUREMENTS

SAN ANGFLO, TEXAS $31 \mathrm{~N}$

FL I GHT NO.

DATE

BED VOL. $\delta C-13$

CONC.
EXCESS SPEC. ACT .
C-14

C-14 EXCESS

EXCESS WT.AVG. 5

(DPM/GC) $110^{5}$ ATOM (KM)

$$
\begin{array}{ll}
\text { (CC) } & \text { (PER MIL } \\
& \\
3920 & -9.4 \\
1500 & -3.7
\end{array}
$$$$
-8.5
$$$$
-8.2
$$

$1312 x$

$1314 x$

$1316 x$

$1317 x$

$1318 x$

$1319 x$

$1320 x$

$-$

\footnotetext{
A. BFD

B.

C. NO ANALYSIS OF $\delta C-13$ FOR BED 1

D. SPECIFIC ACTIVITY NOT COUNTED FOR BED 2
} 
TABLE 1

STRATOSPHERIC CARBON-14 MEASUREMENTS

SAN ANGELO, TEXAS 3IN

FLIGHT

NO.

$\begin{array}{llll} & \text { BEO VOL. } & \delta \mathrm{C}-13 \\ \text { DATE ALT NO. CO-2 } & \text { CONC. }\end{array}$

EXCESS

SPEC.

ACT.

C-14

C-14 EXCESS

EXCESS WT.AVG. $M$

A

(KM) (CC) (PER MIL) (DPM/GC) $\left(10^{5}\right.$ ATOMS/G AIR)

$\begin{array}{cccccccc}1321 \times \quad 110369 & 23.9 & 1 & 3500 & -9.2 & 26.6 & 150.0 & 150.4 \\ & 2 & 580 & +0.1 & 27.1 & 152.8 & \end{array}$

$\begin{array}{llllllll}1322 \times & 110569 & 32.3 & 1 & 525 & -9.2 & 25.1 & 141.6 \\ & 2 & 340 & & & \end{array}$

$\begin{array}{llllllll}1323 x & 110669 & 26.2 & 1 & 2355 & 23.8 & 134.2 & 135.8 \\ & & 2 & 1112 & 24.7 & 139.3 & \end{array}$

$\begin{array}{lllllllll}1326 \times & 010770 & 21.4 & 1 & 2500 & -7.2 & 24.0 & 135.4 & 133.3 \\ 2 & 400 & +1.6 & 21.4 & 120.7 & \end{array}$

$\begin{array}{llllllll}1327 \times & 010870 & 23.8 & 1 & 4200 & -6.6 & 25.8 & 145.5\end{array}$

$+0.2$

A

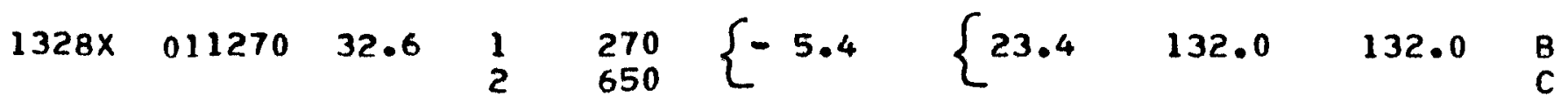

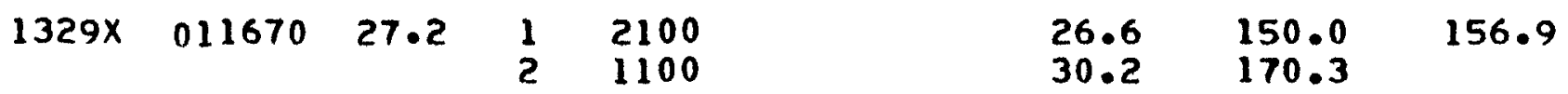

$\begin{array}{rrrrrrr}1331 \times \quad 031270 & 21.5 & 1 & 3250 & 25.7 & 144.9 & 142.6 \\ & & 2 & 600 & 23.2 & 130.8 & \end{array}$

$\begin{array}{cccccccc}1332 \times & 031370 & 24.3 & 1 & 3350 & 27.4 & 154.5 & 151.1\end{array}$

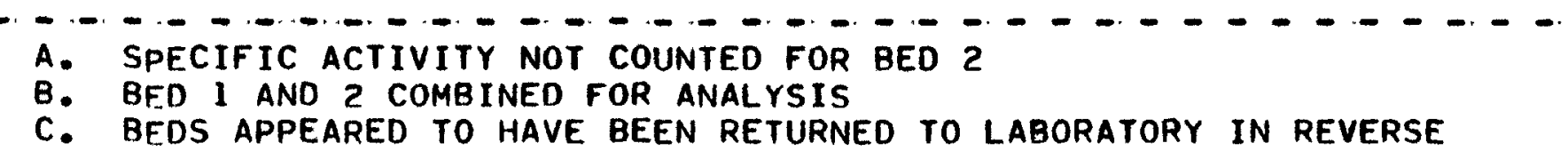


SAN ANGELO, TEXAS 3IN

FLIGHT NO.

DATE

ALT VOL. $\quad \delta C-13$

CONC.

EXCESS

ACT.

C- 14

C -14

EXCESS

EXCESS WT.AVG.

$\left(10^{5}\right.$ ATOMS/G AIR)

(KM)

(CC) (PER MIL) (DPM/GC)

$\begin{array}{lllll}1333 \times & 031770 & 27.2 & 1 & 2500 \\ & & & 1300\end{array}$

$$
25.1 \quad 141.6 \quad 148.5
$$

28.7

$\{23.9\{134.8$

$134.8 \quad A$

$\begin{array}{lllll}1334 \times & 032370 & 32.9 & 1 & 650 \\ & & & 4\end{array}$

$21.8 \quad 123.0$

$\begin{array}{rrrrr}1337 \times & 050770 & 32.6 & 1 & 730 \\ & & & 2 & 95\end{array}$

$24.0 \quad 135.4$

$\begin{array}{rrrrrr}1346 & 090270 & 21.2 & 1 & 2140 & -4.6 \\ & & & 175 & -0.6\end{array}$

$\begin{array}{llllll}1347 & 090970 & 24.6 & 1 & 1940 & -11.2\end{array}$

$24.7 \quad 139.3 \quad 138.9$

$1348 \quad 091170 \quad 32.6$

$\begin{array}{ll}1 & 476 \\ 2 & 195\end{array}$

$-4.7$

$\{20.6$

137.1

B

$\begin{array}{lllll}1349 & 091870 & 32.7 & 1 & 350\end{array}$

$2 \quad 280$

$-18 \cdot 5$
$-9 \cdot 6$

$\{22 \cdot 7\{128 \cdot 0$

128.0

A

$\begin{array}{lllll}1350 & 091970 & 27.5 & 1 & 880\end{array}$

$2 \quad 400-7.8$

$\{25 \cdot 2$

$\{142 \cdot 1$

142. 1 A

$\begin{array}{llllll}1351 & 092070 & 36.3 & 1 & 290 & -13.5\end{array}$

$\left\{17.1\left\{\begin{array}{lll}96.4 & 96.4 \quad A\end{array}\right.\right.$

\section{A. BE}

B. BED 1 AND 2 COMBINED FOR SPECIFIC ACTIVITY ANALYSIS

B. SPECIFIC ACTIVITY NOT COUNTED FOR BED 2 
TABLE 1

STRATOSPHERIC CARBON-14. MEASUREMENTS

SAN ANGELO, TEXAS 3IN

FLIGHT NO.

DATE ALT NO. $\begin{array}{ll}\text { BED } & \text { VOL. } \\ & \text { CO-2 }\end{array}$

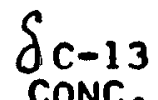
EXCESS SPEC. ACT.

$\mathrm{C}-14$ EXCESS EXCESS WT.AVG.

\begin{tabular}{|c|c|c|c|c|c|c|c|c|}
\hline 1352 & 110370 & $32 \cdot 9$ & $\begin{array}{l}1 \\
2\end{array}$ & $\begin{array}{l}870 \\
250\end{array}$ & $\begin{array}{l}-11.3 \\
-4.8\end{array}$ & $\begin{array}{l}23 \cdot 2 \\
22 \cdot 5\end{array}$ & $\begin{array}{l}130.8 \\
126.9\end{array}$ & 129.9 \\
\hline 1353 & 110470 & 23.9 & $\begin{array}{l}1 \\
2\end{array}$ & $\begin{array}{l}3600 \\
1075\end{array}$ & $\begin{array}{l}-8.4 \\
-2.3\end{array}$ & $\begin{array}{l}25.2 \\
24.8\end{array}$ & $\begin{array}{l}142.1 \\
139.9\end{array}$ & 141.6 \\
\hline 1354 & 111070 & $21 \cdot 2$ & $\begin{array}{l}1 \\
2\end{array}$ & $\begin{array}{r}4800 \\
500\end{array}$ & $-11 \cdot 5$ & $\begin{array}{l}22.7 \\
---\end{array}$ & $\begin{array}{l}128.0 \\
-\infty-\infty\end{array}$ & \\
\hline 1355 & 111770 & $27 \cdot 3$ & $\begin{array}{l}1 \\
2\end{array}$ & $\begin{array}{l}2970 \\
1100\end{array}$ & $\begin{array}{l}-10.2 \\
-4.6\end{array}$ & $\begin{array}{l}23.7 \\
21.8\end{array}$ & $\begin{array}{l}133.7 \\
123.0\end{array}$ & 130.8 \\
\hline 1367 & 030371 & $21 \cdot 5$ & $\begin{array}{l}1 \\
2\end{array}$ & $\begin{array}{r}3800 \\
625\end{array}$ & $\begin{array}{r}-5.5 \\
+\quad 0.9\end{array}$ & $\begin{array}{l}21 \cdot 4 \\
21 \cdot 5\end{array}$ & $\begin{array}{l}120 \cdot 7 \\
121 \cdot 3\end{array}$ & 120.8 \\
\hline 1368 & 031071 & $24 \cdot 6$ & $\begin{array}{l}1 \\
2\end{array}$ & $\begin{array}{r}4300 \\
940\end{array}$ & $\begin{array}{r}-6.8 \\
+\quad 0.3\end{array}$ & $\begin{array}{l}22 \cdot 0 \\
21 \cdot 2\end{array}$ & $\begin{array}{l}124.1 \\
119.6\end{array}$ & 123.3 \\
\hline 1371 & 031771 & 27.7 & $\begin{array}{l}1 \\
2\end{array}$ & $\begin{array}{l}3350 \\
1600\end{array}$ & $\begin{array}{l}-7.0 \\
-3.5\end{array}$ & $\begin{array}{l}22.4 \\
23.5\end{array}$ & $\begin{array}{l}126.3 \\
132.5\end{array}$ & 128.3 \\
\hline 1372 & 032271 & 27.9 & $\begin{array}{l}1 \\
2\end{array}$ & $\begin{array}{l}2575 \\
1500\end{array}$ & $\begin{array}{l}-9.7 \\
-6.2\end{array}$ & $\begin{array}{l}23 \cdot 2 \\
22 \cdot 2\end{array}$ & $\begin{array}{l}130.8 \\
125.2\end{array}$ & 128.7 \\
\hline 1376 & 052571 & 27.5 & $\begin{array}{l}1 \\
2\end{array}$ & $\begin{array}{l}2975 \\
1430\end{array}$ & $\begin{array}{l}-8.4 \\
-3.1\end{array}$ & $\begin{array}{l}20.7 \\
20.7\end{array}$ & $\begin{array}{l}116.7 \\
116.7\end{array}$ & 116.7 \\
\hline
\end{tabular}

A. LOST IN ANALYSIS

B. SAMPLER DAMAGED ON IMPACT, POSSIBLE CONTAMINATION 
SAN ANGFLO, TEXAS 3IN

FLIGHT NO. DATE
BED VOL. $\delta \mathrm{C}-13$ ALT NO. CO-2 CONC.
EXCESS SPEC. ACT.
C-14 EXCESS EXCESS WT.AVG.

(CC) (PER MIL) (DPM/GC) $\left(10^{5}\right.$ ATOMS/G AIR)

(KM)

$R$
$E$
$M$
$A$
$R$
$K$
$S$

137

$$
052671 \quad 32.4
$$$$
\begin{array}{lll}
1 & 925 & -11.3 \\
2 & 600 & -8.9
\end{array}
$$

21.8 21.4

123.0 120.7

$\begin{array}{lll}1378 & 052871 \quad 24.6\end{array}$

$$
\begin{array}{lll}
1 & 3425 & -6.3 \\
2 & 1250 & -1.7
\end{array}
$$

22.0

21.3

124.1 120.1

$\begin{array}{lllll}1381 & 060671 & 36.6 & 1 & 465 \\ & & & 2 & 100\end{array}$

19.6 20.0
110.5 112.8
122.1

123.0

110.9 
TABLE 1 STRATOSPHERIC CARBON-14 MEASUREMENTS

ALBROOK AFB, CANAL ZONE $9 N$

FLIGHT NO.
BED VOL. $\quad \delta \mathrm{C}-13$

CONC.
EXCESS

SPEC.

ACT.
C-14

C-14 EXCESS

EXCESS WT.AVG. 5

(CC) (PER MIL) (DPM/GC) (10 ATOMS/G AIR)
$R$
$E$
$M$
$A$
$R$
$K$
$S$

A

$18.7 \quad 105.5$

$19.8 \quad 111.7 \quad 110.5$

19.2108 .3

$13.5 \quad 76.1$

$14.6 \quad 82.3$

77.0

$-7.3$

21.4

21.0

120.7

118.4

120.3

$-2.7$

17.9

101.0

102.1

$19.0 \quad 107.2$

$19.2 \quad 108.3$

108.1

$-2.8$

$19.0 \quad 107.2$

$13 \cdot 8$

77.8

61.5

75.4

$-3.0$

$19.7 \quad 111.1$

B

$\begin{array}{lllllllll}120 & 012271 & 32.4 & 1 & 1350 & -11.5 & 20.3 & 114.5 & 114.9\end{array}$ $450 \quad-16.5 \quad 20.6 \quad 116.2$

A. LEAK IN THE VACUUM SYSTEM, DATA SUSPECT.

B. LOST IN PURIFICATION. 
TABLE 1

STRATOSPHERIC CARBON-14 MEASUREMENTS

ALBROOK AFB, CANAL ZONE 9N

FLIGHT

NO.

DATE ALT NO. CO-2

EXCESS

SPEC.

ACT .

C -14

C-14

EXCESS

EXCESS

R

WT.AVG.

5

(KM) (CC) (PER MIL) (DPM/GC) $(10$ ATOMS/G AIR)

\section{1}

$$
\begin{array}{rrrrr}
040371 & 21.4 & 1 & 5400 & -6.4 \\
& & 2 & 940 & +0.1
\end{array}
$$

15.6

13.9

88.0

78.4

12

$$
\begin{array}{lllll}
040471 & 24.4 & 1 & 3800 & -14.2 \\
& & 1100 & -2.2
\end{array}
$$

17.2

18.0

97.0

101.5

123

$$
04057127.5
$$

$\begin{array}{ll}1 & 3000 \\ 2 & 1525\end{array}$

$-8.2$

$-3.1$

20.4

20.4

115.1

115.1

124

06067132.0

$\begin{array}{rr}1 & 1010 \\ 2 & 535\end{array}$

-10.1
-3.8

19.2

20.8

108.3

117.3

86.6

98.0

115.1

111.5 
TABLE 1 STRATOSPHERIC CARBON-14 MEASUREMENTS

LONGREACH, AUSTRALIA 235

FLIGHT NO.

DATE

BED VOL. $\delta_{\mathrm{C}-13}$

ALT NO. CO-2 CONC.

(KM)
EXCESS SPEC. ACT.

$\begin{array}{ccc}C-14 & R \\ C-14 & & \\ \text { EXCESS } & \end{array}$ C-14 EXCESS E A 5 (CC) (PER MIL) (DPM/GC) (10 ATOMS/G AIR)

512

01277124.1

$$
\begin{array}{rr}
1 & 3200 \\
2 & 195
\end{array}
$$$$
-5.1
$$

25.1

141.6

$\begin{array}{rrr}1 & 2840 & -3.4 \\ 2 & 600 & -6.0\end{array}$

22.3

19.2

125.8 108.3

122.8

513

$012971 \quad 27.3$

2

$\begin{aligned} 1300 & -6.4 \\ 810 & -4.9\end{aligned}$

21.6

21.8

121.8

123.0

122.3

$\begin{array}{llll}514 & 020371 \quad 32.0 \quad 1\end{array}$

$\begin{array}{ll}1 & 700 \\ 2 & 250\end{array}$

$-10.2$

$19.4 \quad 109.4$

$\begin{array}{llll}522 & 042771 & 19.9 & 1 \\ & & & 2 \\ 523 & 042971 & 23.5 & 1 \\ & & & 2\end{array}$

$\begin{array}{rrrrr}524 & 043071 & 26.5 & 1 & 2500 \\ & & & 2 & 380\end{array}$

$\begin{array}{ll}21.2 & 119.6 \\ 19.5 & 110.0\end{array}$

118.8

525

$\begin{array}{rrrr}050371 \quad 31.1 & 1 & 1000 \\ & & 2 & 300\end{array}$

$-6.7$

$\begin{array}{lll}22.3 & 125.8 & 125.6 \\ 22.0 & 124.1 & \\ 19.2 & 108.3 & 112.3 \\ 22.3 & 125.8 & \end{array}$

A. NO ANALYSIS OF SPECIFIC ACTIVITY FOR BED 2. 
MILDURA, AUSTRALIA 345

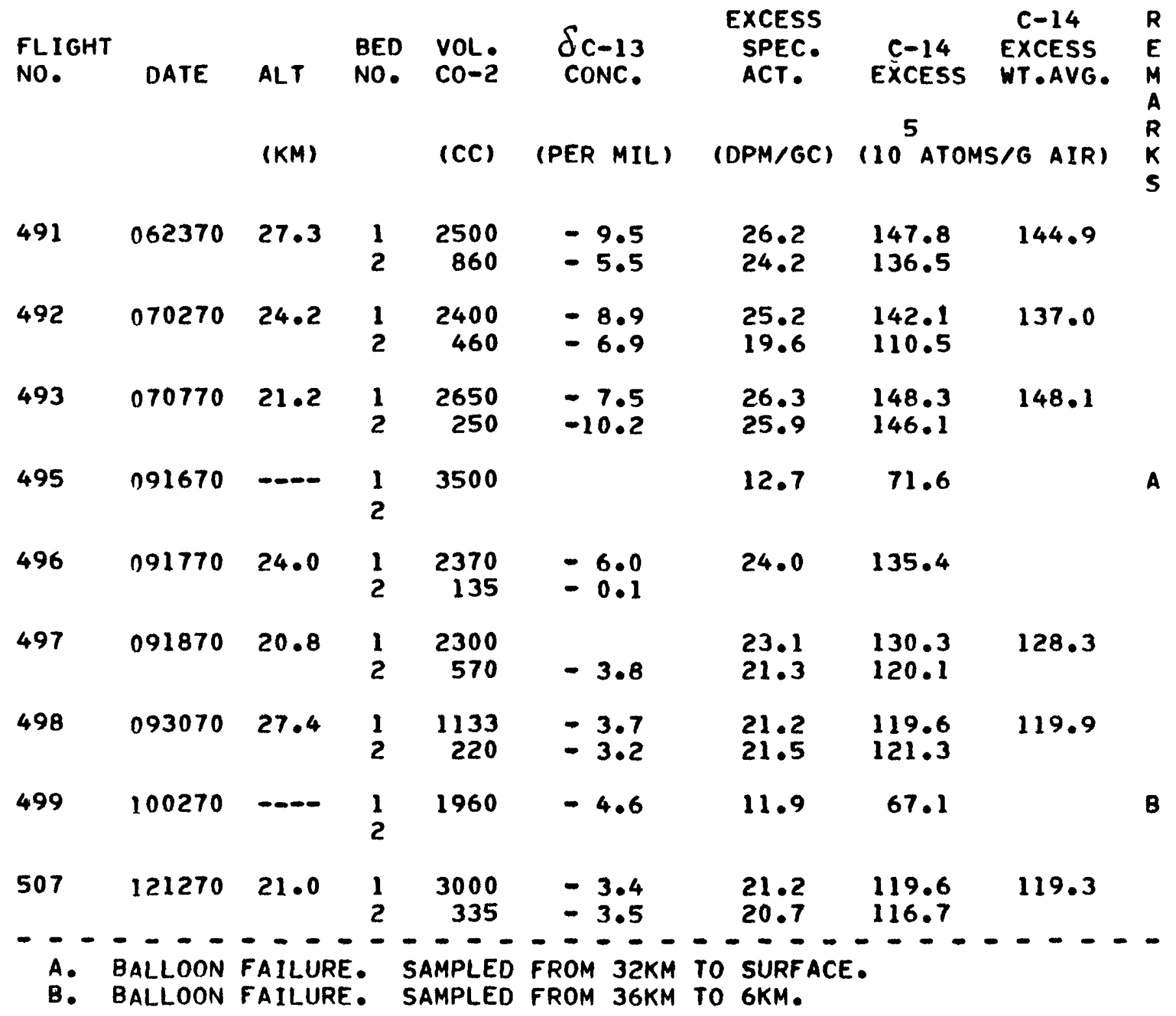


TABLE 1

STRATOSPHERIC CARBON-14 MEASUREMENTS

MILDURA, AUSTRALIA 345

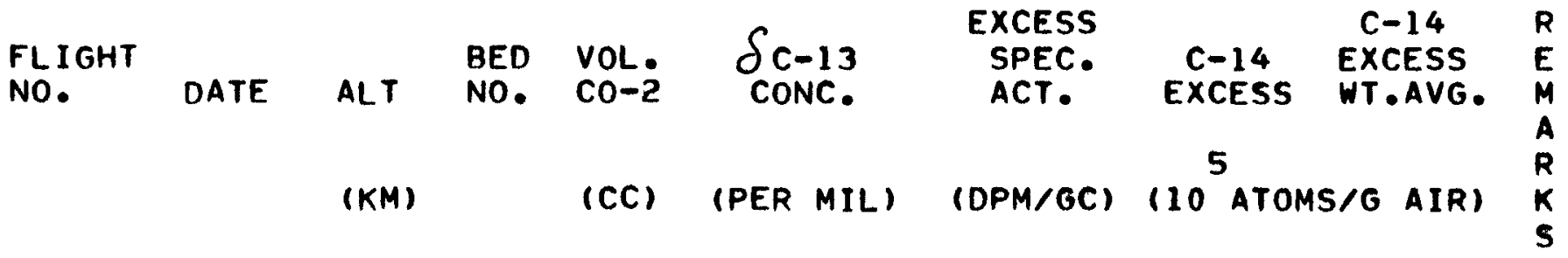

\begin{tabular}{rrrrrrrrr}
508 & 121370 & 24.2 & 1 & 1700 & -1.9 & 22.7 & 128.0 & 130.0 \\
& & & 2 & 860 & -8.1 & 23.9 & 134.8 & \\
509 & 121570 & 27.1 & 1 & 1920 & -8.3 & 24.2 & 136.5 & 133.6 \\
& & & 2 & 260 & & 19.9 & 112.2 & \\
515 & 031171 & 23.4 & 1 & 3070 & -6.6 & 23.4 & 132.0 & 132.6 \\
& & & 2 & 700 & -3.8 & 24.0 & 135.4 & \\
516 & 031671 & 26.8 & 1 & 1900 & -7.6 & 23.6 & 133.1 & 131.4 \\
& & & 2 & 530 & -3.6 & 22.2 & 125.2 & \\
518 & 032371 & 20.9 & 1 & 3150 & -10.0 & 23.2 & 130.8 & 130.0 \\
& & & 2 & 265 & +1.7 & 21.4 & 120.7 & \\
519 & 032471 & 32.8 & 1 & 915 & -12.3 & 22.6 & 127.5 & 128.5 \\
& & & 2 & 260 & -4.9 & 23.4 & 132.0 & \\
521 & \multirow{2}{*}{040571} & 36.5 & 1 & 550 & -12.3 & 20.3 & 114.5 & 114.6 \\
& & & 2 & 165 & -3.2 & 20.4 & 115.1 &
\end{tabular}




\section{Table 2. Argonne National Laboratory $\delta$ C-13 (0/00) Determinations.}

Collector

1. Molecular Sieve

Bed-1 (Primary)

Bed-2 (Breakthrough)

Wt. Ayg. (Bed 1 and 2)
$-8.5$

$-4.5$

$-7.7$

2.7

1.0

3.1

$-8.1$

4.0
Standard

Deviation

81

77

72

2. Whole Air

99 


\section{Table 3. Stratospheric Burden of Excess C-14 (1026 atoms) from 21 to $37 \mathrm{~km}$.}

$$
\text { Sept. - Dec. } 1970
$$

N.H.

S.H.

Tota1

Est1mated*

Total
12.8

12.4

25.2

16
Jan. - June 1971

12.1

12.6

24.7

15

*Assumes an effective half-residence time of 60 months between June 1964 to July 1966. 


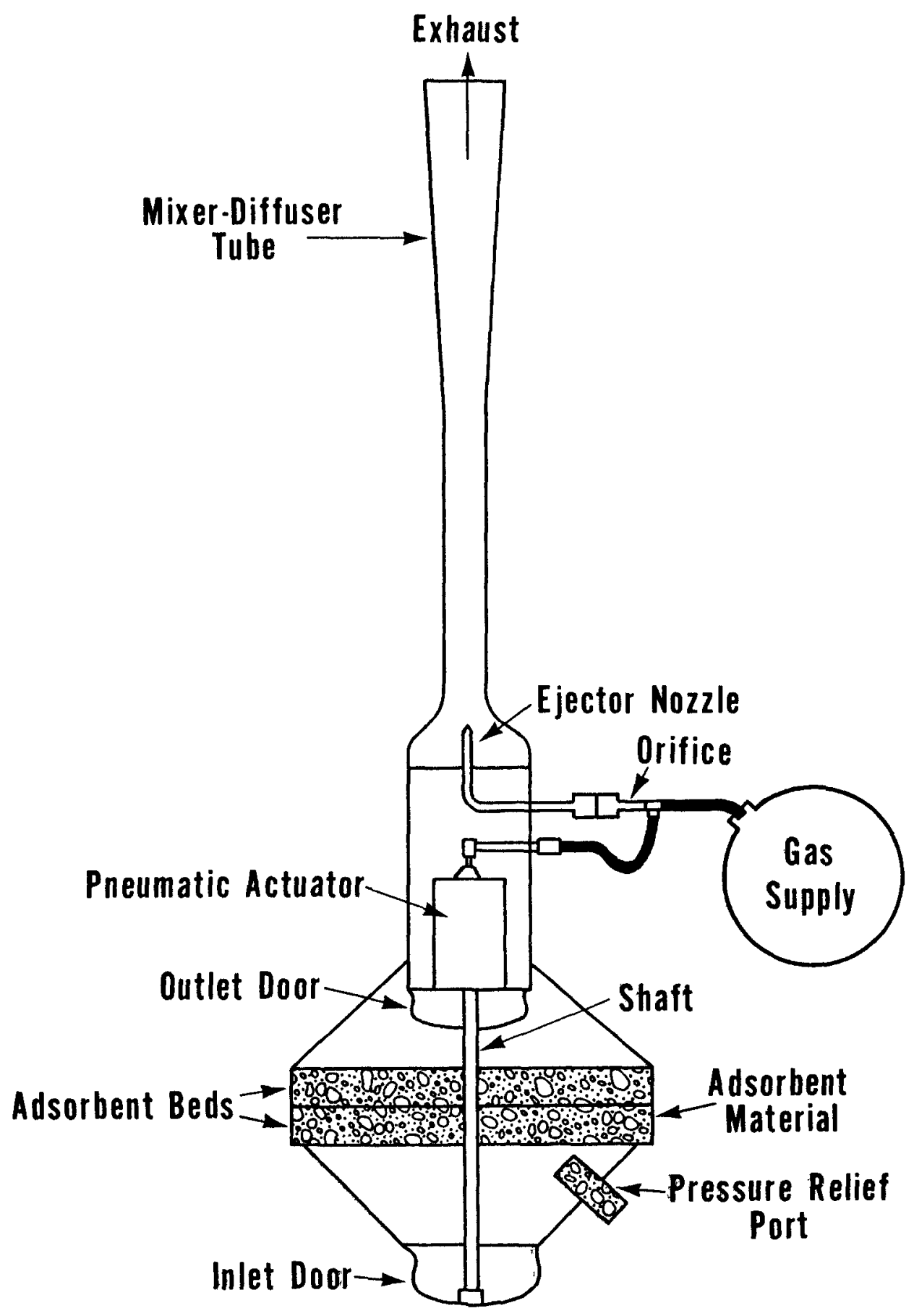

Fig.1: Schematic Diagram of The Molecular Sieve Sampler (Ashenfelter et al, 1972) 


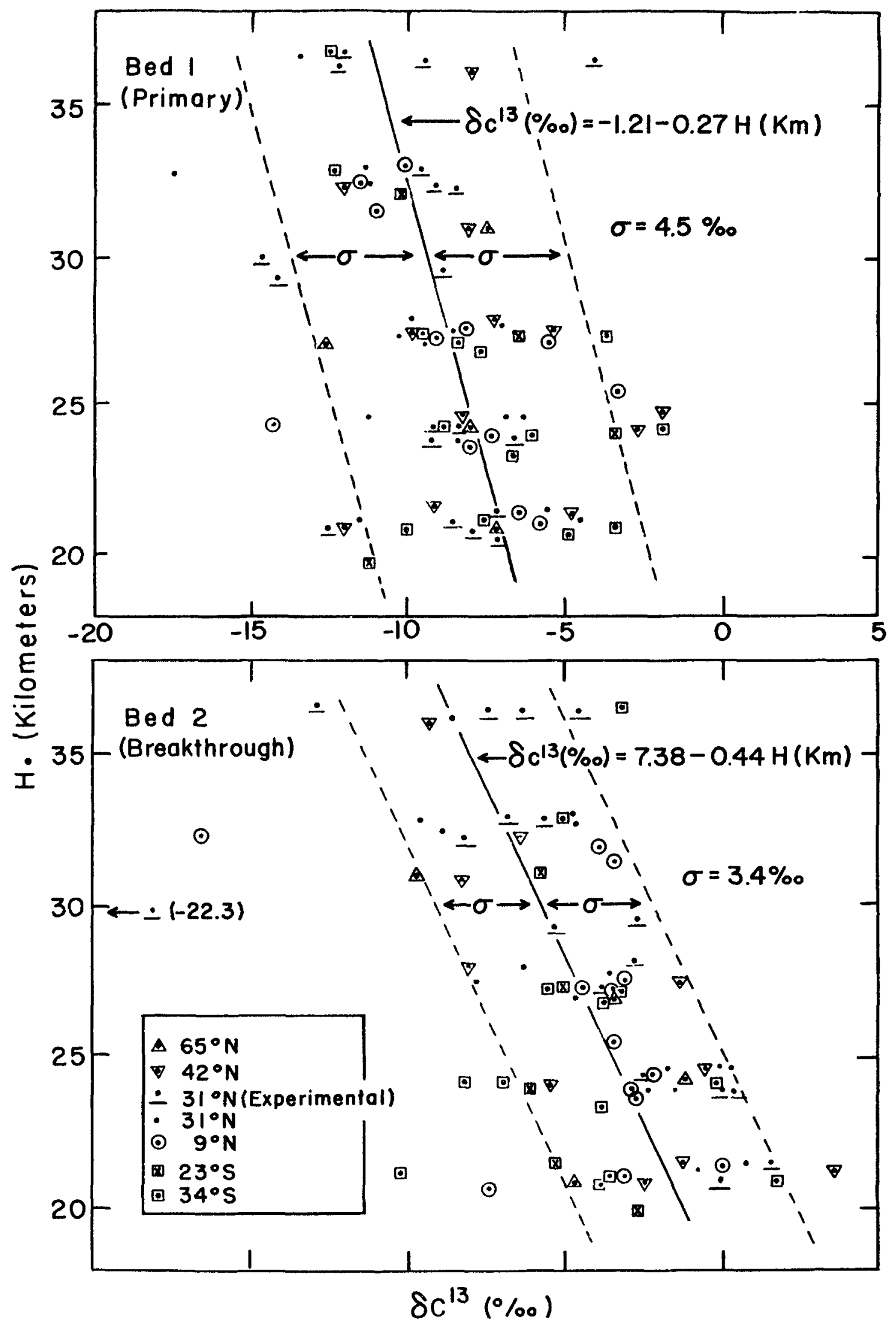

Fig2. Vertical Distribution of $\delta c^{13}$ (per mil) 


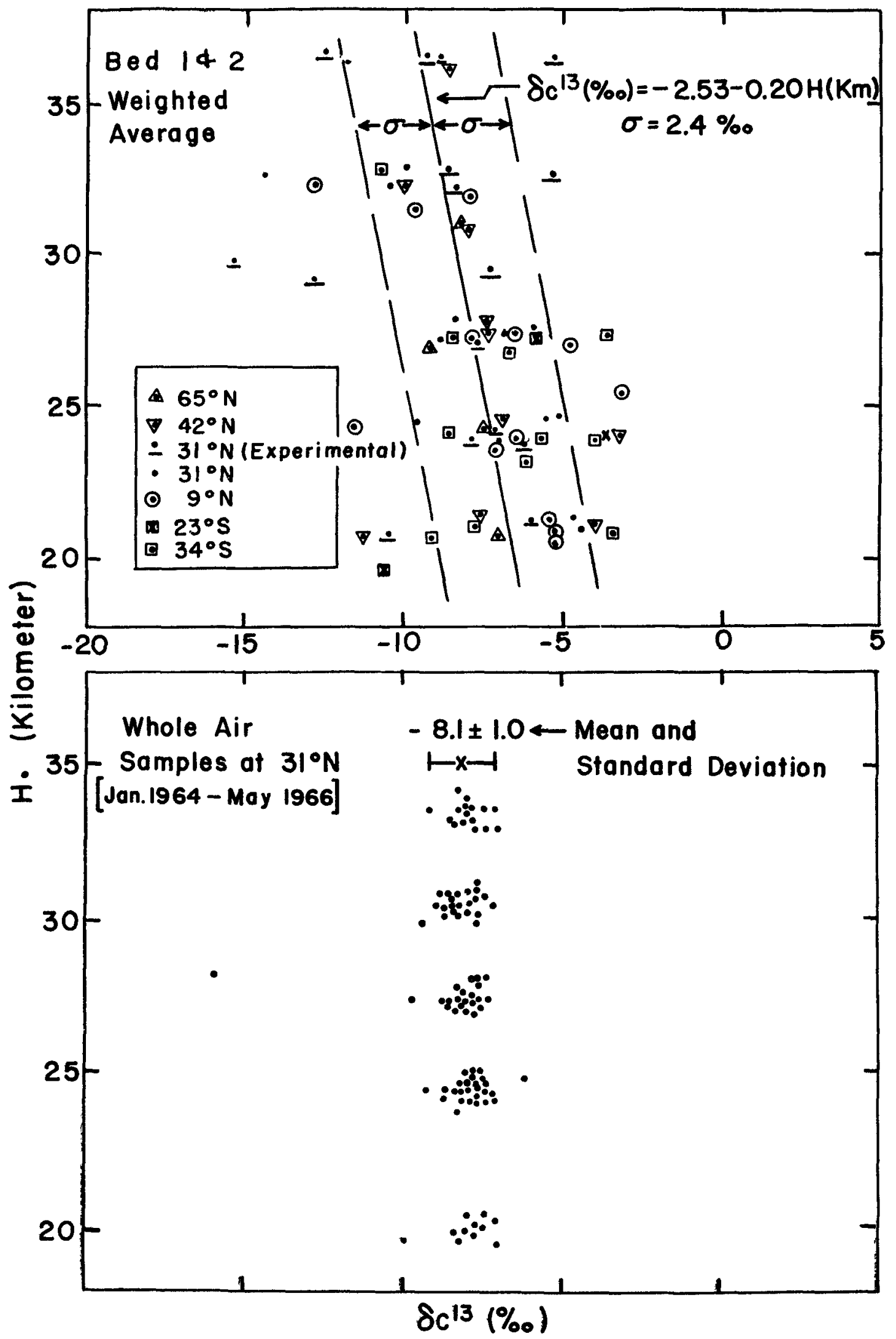

Fig 3. Vertical Distribution of $\delta c^{13}$ (per mil) 


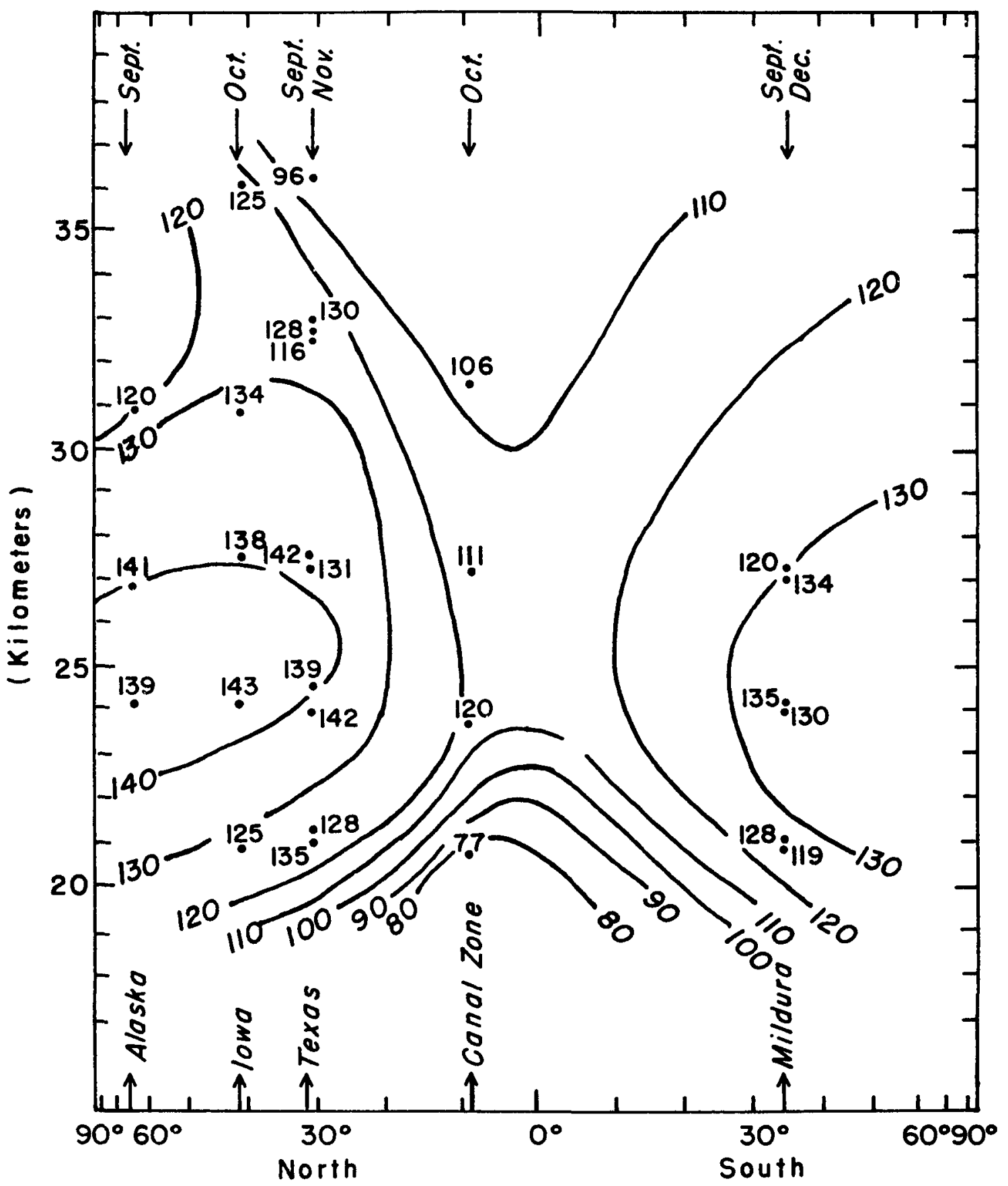

Fig 4. Excess $\mathrm{C}-14\left(10^{5}\right.$ atoms/gram of air )

September - December, 1970 


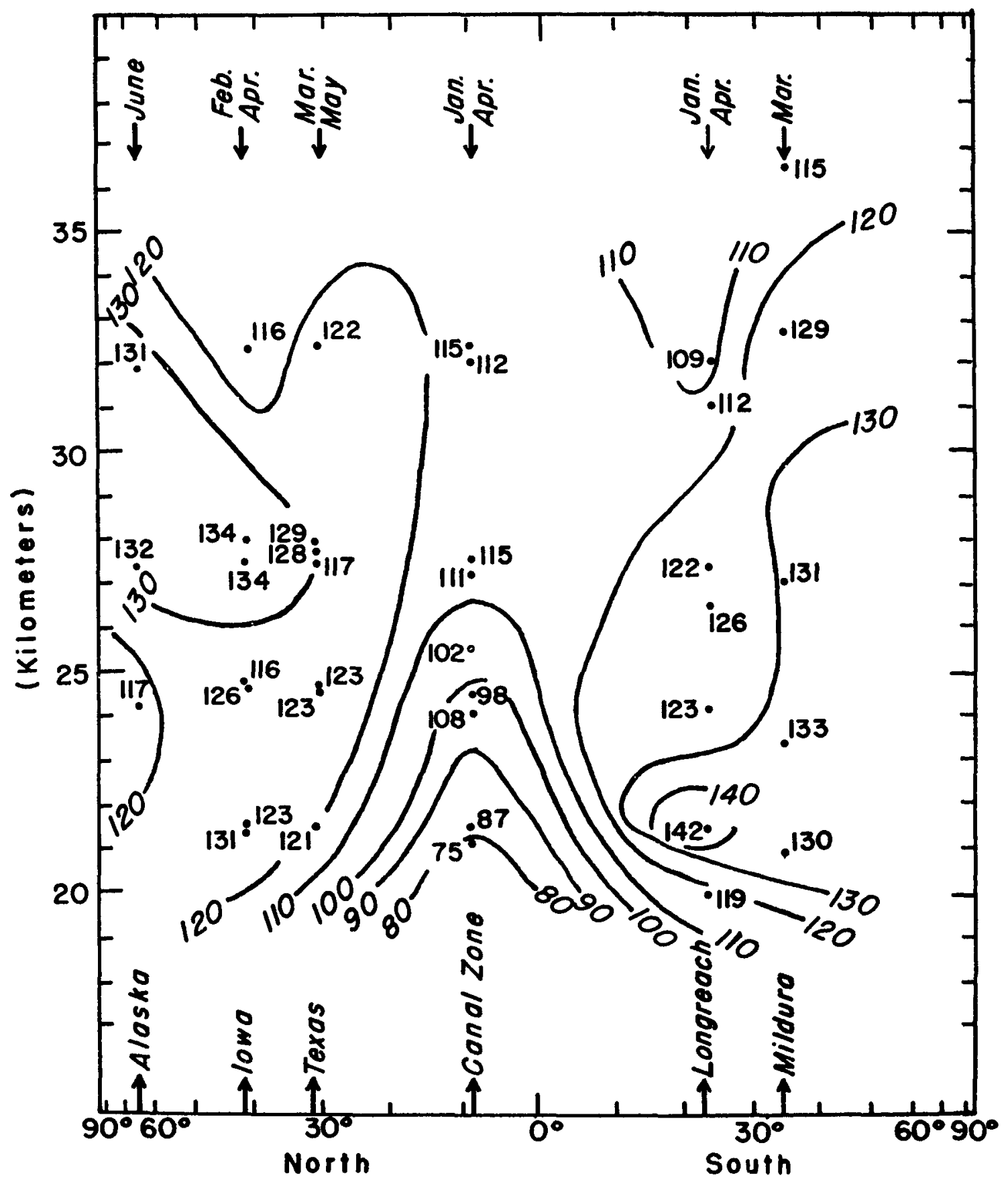

Fig 5. Excess C-14 (10 5 atoms/grams of air) January - June, 1971 
by B: G. Bennett (HASL)

\section{ABSTRACT}

From the long term HASL programs of Sr-90 deposition measurement and analysis of $\mathrm{Sr}-90$ in milk and total diet in New York City, methods have been developed for making reliable estimates of $\mathrm{Sr}-90$ levels in milk and total diet. The deposition-milk relationship includes a lag term to account for use of stored feed and exponential removal of the contribution from deposition of preceding years. Exponential removal, to account for decay and reduced uptake availability of $\mathrm{Sr}-90$ in soil, amounts to $13 \%$ per year in New York. The diet-milk ratio, commonly used to estimate dietary intake of $\mathrm{Sr}-90$ from $\mathrm{Sr}-90$ intake in milk, varies considerably about 1.4 for New York and would be expected to vary similarly in other areas through periods of changing deposition. Improvements in dietary Sr-90 intake estimates are achieved by using quarterly milk measurements and estimating Sr-90 intake in non-dairy foods from the Sr-90 intake in milk in the preceding quarter.

The Health and Safety Laboratory began a program to measure global Sr-90 fallout in 1954, shortly after large scale atmospheric testing began to introduce significant amounts of $\mathrm{Sr}-90$ into the environment. The continuous record of Sr-90 deposition measurements in New York City is shown in Figure 1. Monthly analyses of Sr-90 in milk from New York City also began in 1954 (Figure 2). Total dietary Sr-90 intake in New York City, estimated from quarterly analyses 


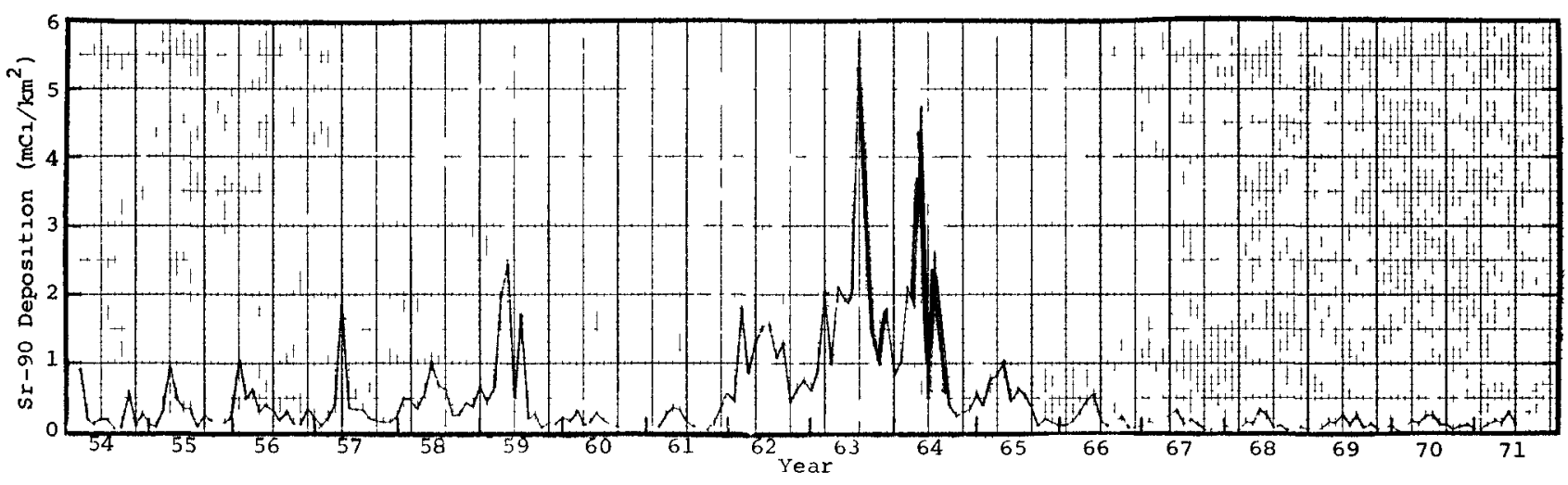

Fig. 1. Monthly Sx-90 deposition in New York City.

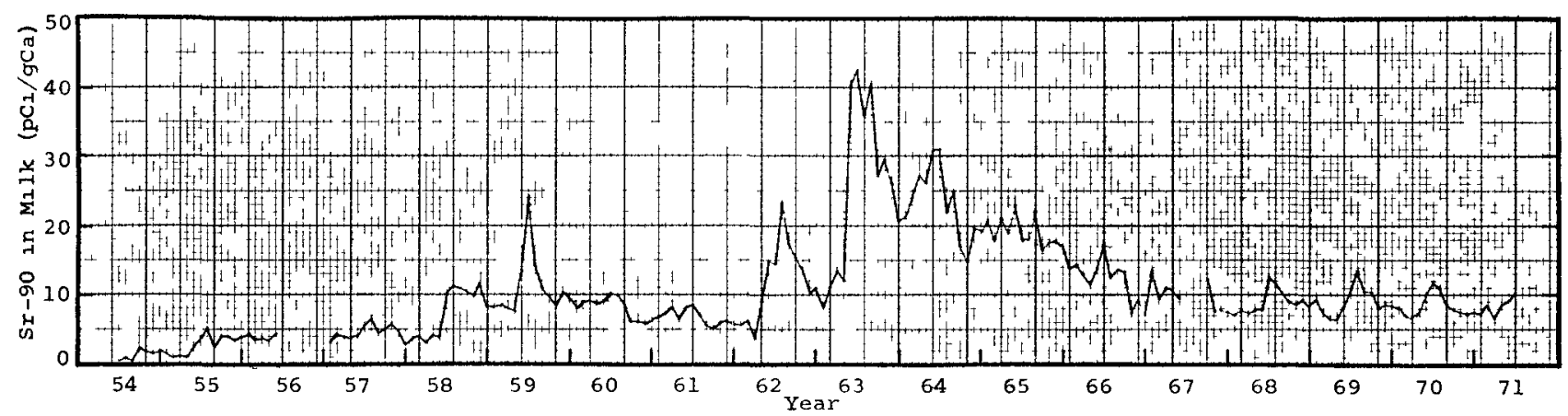

Fig. 2. Monthly Sr-90 concentration in milk in New York City.

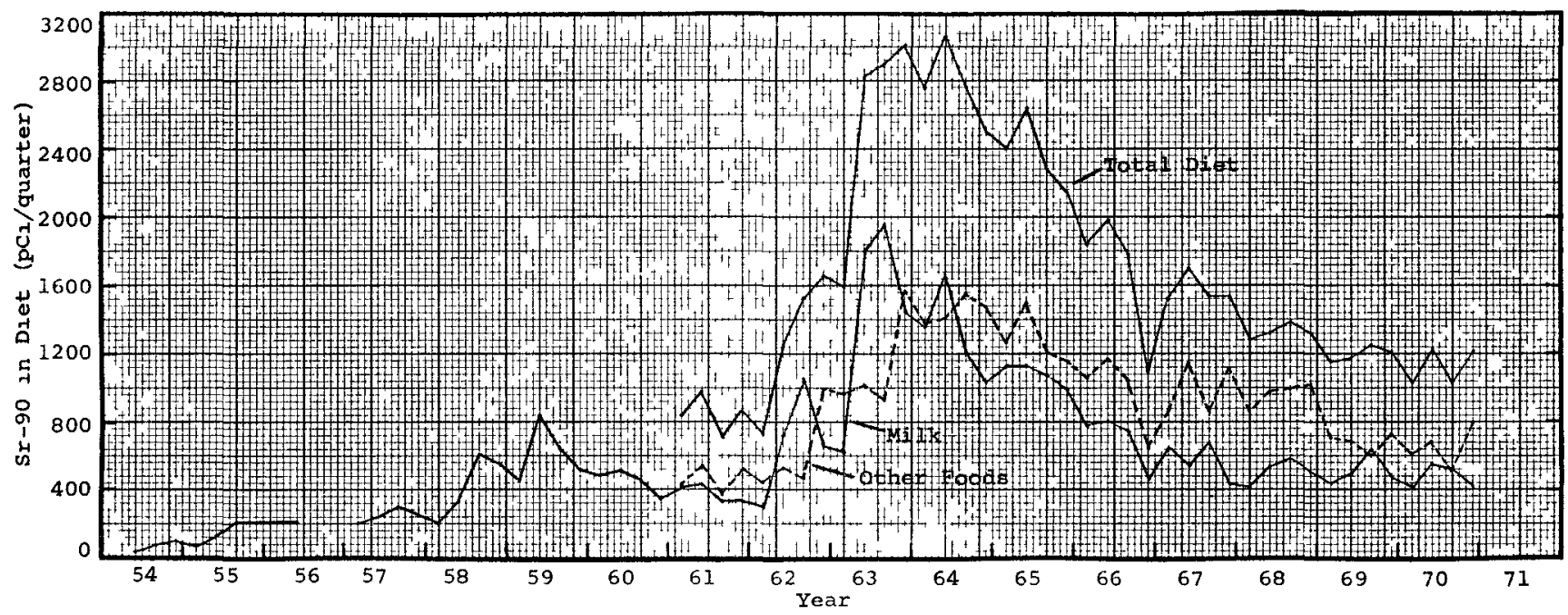

Fig. 3. Quarterly dietary $5 x-90$ intake in New York. 
of 19 representative food items, has been reported since 1960 (Figure 3)。

From these relatively long-term monitoring programs, it is possible to make fairly good correlations between Sr-90 deposition and the levels in milk and total diet. Estimation of the transfer of $\mathrm{Sr}-90$ fallout to $\mathrm{milk}$ and diet under varying conditions of deposition can now be made rather reliably. This report updates the experience gained from these studies.

Correlation of Sr-90 Deposition with Levels in Milk

The Sr-90 levels in milk have traditionally been described by a model which relates the yearly average level in milk to the fallout rate in the current year and the cumulative deposit in the soil. The model, sometimes known as the UN model because of its use by the United Nations Scientific Committee on the Effects of Atomic Radiation, was devised by Tajima.

As the model developed, a lag factor to account for use of stored feed was added, and most recently, exponential removal has been included in the cumulative deposit term to account for losses due to downward movement in soil and other physical and chemical changes which reduce the availability 
of Sr-90 for uptake by plants. O'Brien has proposed such an updated formula for use by the UN committee.

The model which best describes the New York data is given by the following formula:

$$
\begin{gathered}
M_{n}=p_{1} F_{n}+p_{2} F_{n-1}+p_{3} \sum_{m=1}^{\infty} F_{n-m} e^{-m \lambda} \\
p_{1}=.69 \quad p_{2}=.21 \quad p_{3}=.20
\end{gathered}
$$

In this model $p_{1}$ is the proportionality constant which includes the rate and deposit effects of the current year's deposition, $\mathrm{p}_{2}$ is the lag factor for the previous year's deposition, and $\mathrm{p}_{3} \mathrm{e}^{-\mathrm{m} \lambda}$ is the deposit factor with exponential removal of the deposition in each of the preceding years, $M_{n}(\mathrm{pCi} / \mathrm{gCa})$ is the average $\mathrm{Sr}-90 / \mathrm{Ca}$ ratio in milk in the year $\mathrm{n}$, and $\mathrm{F}_{\mathrm{n}}$ $\left(\mathrm{mCi} / \mathrm{km}^{2}\right)$ is the $\mathrm{sr}-90$ fallout deposition during the year $\mathrm{n}$. Figure 4 shows the least squares fit to the average yearly Sr-90 concentrations in milk. Estimates from the model are usually within $10 \%$ of the average observed values.

The model above is just slightly modified from the formulation proposed by Bartlett and Russell (3) and applied by them to UK data. The Bartlett-Russell formulation splits the preceding year's deposition and lags only the last half of 


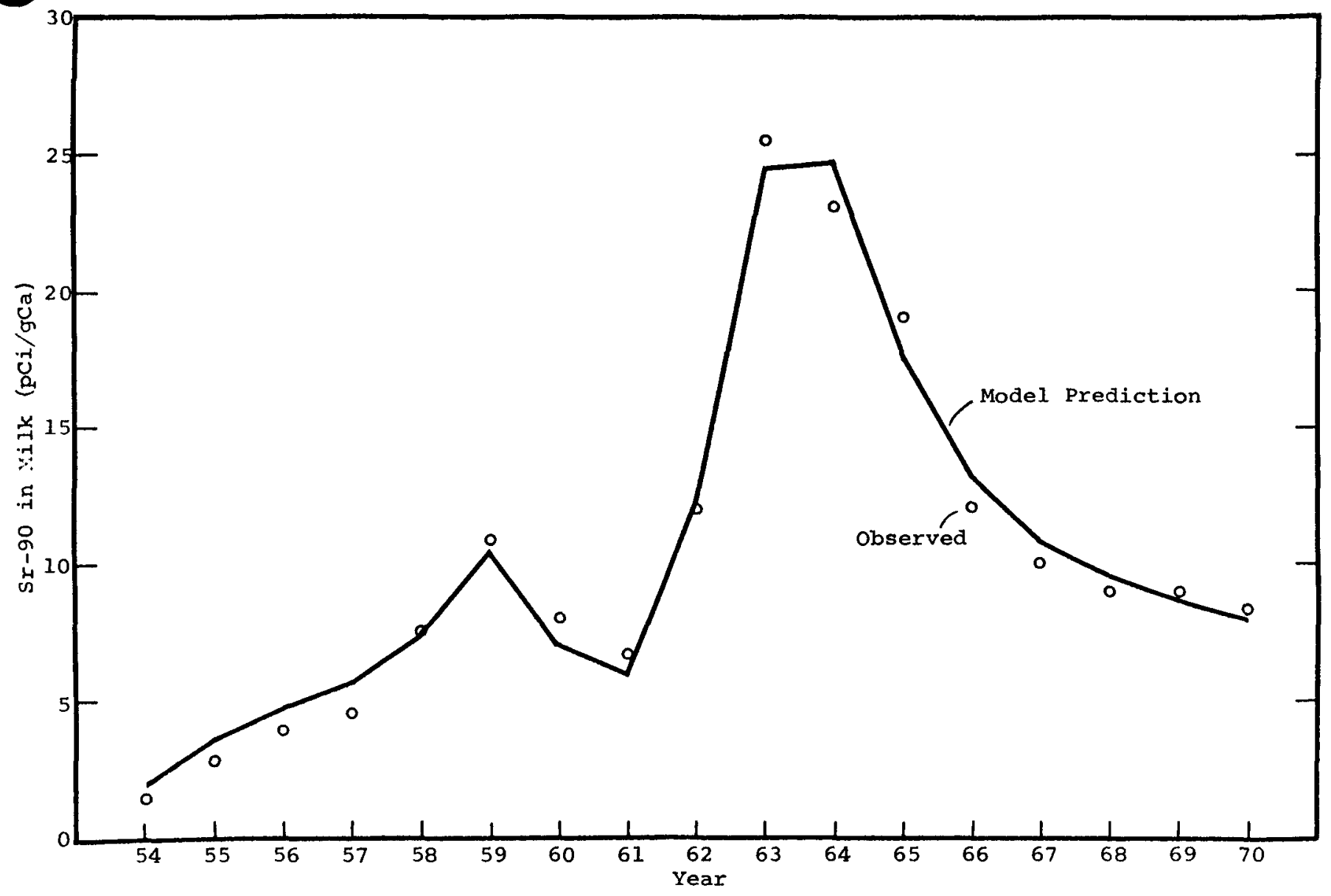

Figure 4. Average yearly Sr-90 concentration in milk in New York City.

the year. The Iag effect is less important in New York $\left(p_{2}=.2 I\right)$ than in the UK $p_{2}=1.4 I$, equivalent to .70 for lag of the entire previous year's deposition), which indicates less use of stored feed in the New York area than in the UK. The other parameters are in ciose agreement $\left(\mathrm{p}_{1}=.69\right.$ and, 70, $\mathrm{p}_{3}=.20$ and. $20, \lambda=.14$ and .18 in New York and in the UK, respectiveIy). 
A model applied to Norwegian data by Hvinden and Lillegraven ${ }^{(4)}$ and another model appiied to Italian data by Van dex Stricht, Gaglione, and de Bartoli (5) include exponential removal but no lag term. The mean residence times of Sr-90 in soil inferred from the exponential removal terms vary in these analyses from 1.9 years in Norway to 5.6 years in the UK and 6,7 years in ItaIy. This may be compared to 7. 1 years determined for New York: corresponding to $11 \%$ per year removal in adition to the $2.4 \%$ radioactive decay.

The Diet-Milk Ratio

A common practice to estimate total dietary intake of Sr-90, short of sampiing many more food Items, has been to multiply the Sr-90/Ca ratio measured for milk by a constant factor, usually 1,4, though 1.0 has been found more appropriate for the UK and values from 2 to 4 are needed in the USSR and Japan due to differences ir the diets.

$$
\text { Diet }(\mathrm{pCi} / \mathrm{gCa})=1.4 \times \mathrm{Milk}(\mathrm{pCi} / \mathrm{gCa})
$$

The factor 1.4 , as an average value for recent years, also applies to New York. A careful look at the variations in this ratio, however, show changes ir time which can quite reasonably be expected. 
For typical western diets, milk and other dairy products

contribute $\sim 60 \%$ of the dietary calcium intake. The diet-milk ratio can thus be written.

$$
\left(\frac{\mathrm{Sr}-90}{\mathrm{Ca}}\right)_{\text {diet }} /\left(\frac{\mathrm{Sr}-90}{\mathrm{Ca}}\right)_{\mathrm{milk}}=.6 \times(\mathrm{Sr}-90)_{\mathrm{diet}^{\prime}}(\mathrm{Sr}-90)_{\mathrm{milk}}
$$

Milk is one of the first food items contaminated following a period of deposition. If milk is the only food contaminated, the diet-milk ratio would be .6 . As the contamination begins to appear in other foods, the diet-milk ratio increases. When milk contributes just over $40 \%$ of the dietary $\mathrm{Sr}-90$ intake, the diet-milk ratio is 1.4 . The variations in the contribution of milk to the total diet $\mathrm{Sr}-90$ intake reflect the variations in amounts of Sr-90 deposition.

Figure 5 shows the changes in the diet-milk ratio for New York from 1961 to 1970. During periods of heavy fallout deposition, 1962-64, the milk contribution was greater than $40 \%{ }^{(6)}$, and the ratio was less than 1.4 . As the levels in grain and vegetables become more important relative to milk, the contribution from milk fell below 40\%, and the diet-milk ratio increased above 1.4. In recent years the ratio has been stabilizing around 1.4 . 


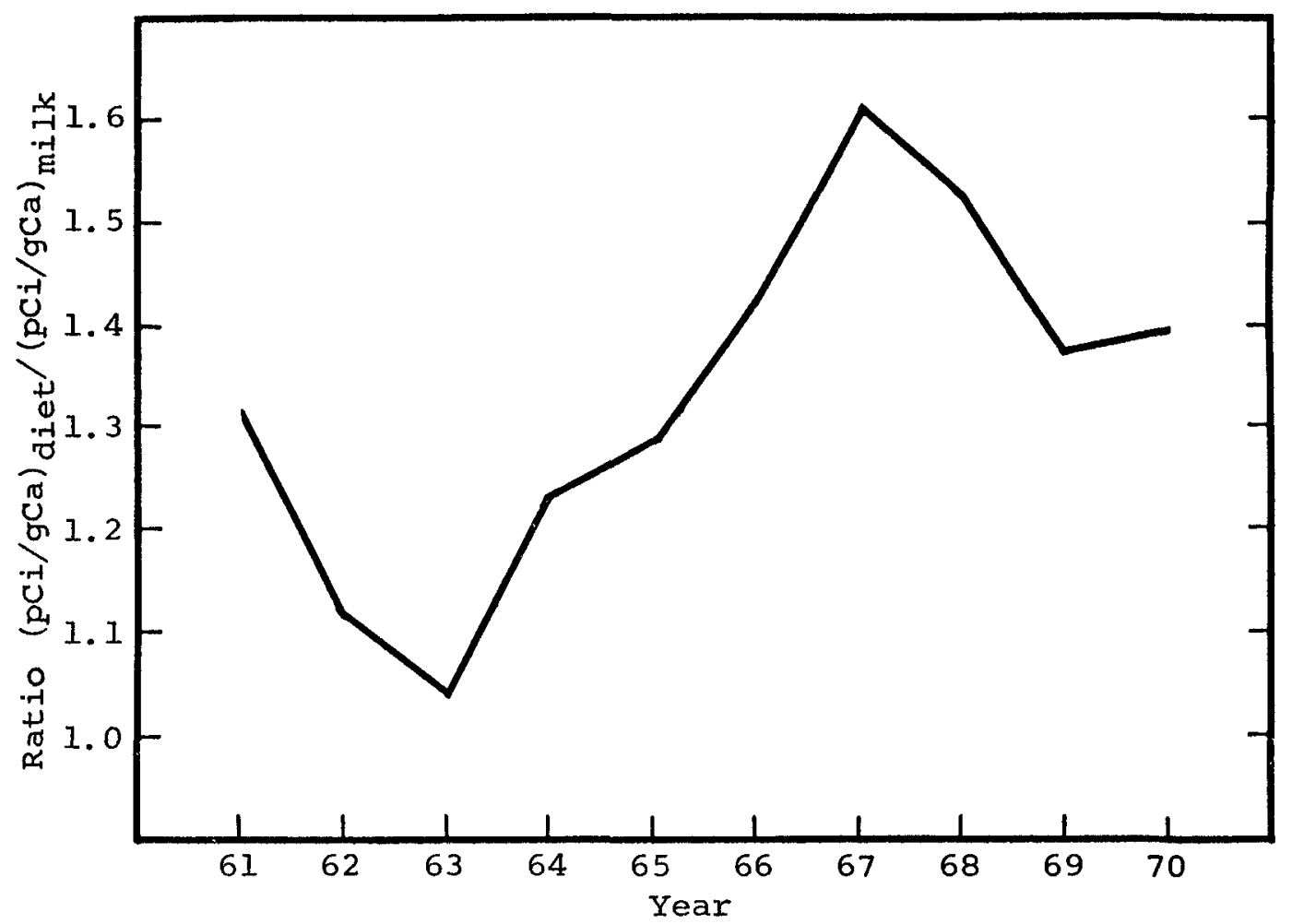

Fig. 5. Diet-milk ratio in New York City.

The use of a constant diet-milk ratio, such as 1.4 , leads to yearly dietary intake estimates which are correct to within about $\pm 50 \%$, but much better estimates of total diet $\mathrm{Sr}-90$ intake can be obtained by adjusting the diet-milk ratio according to the level of deposition. Adjustments similar to those shown in Figure 5 should be helpful.

Estimation of Total Diet Sr-90 Intake from Milk Levels

It would seem that even better use could be made of milk levels to estimate the total diet $\mathrm{Sr}-90$ intake than the use 
of the diet-milk ratio applied to yearly averages. One might, first of all, make use of the quarterly values of $\mathrm{Sr}-90$ in milk, which should usually be available. In obtaining representative average yearly milk levels, measurements should have been made on at least a quarterly basis. One then requires a relation between quarterly intake of $\mathrm{Sr}-90$ in milk and quarterly intake of Sr-90 in other, non-dairy, foods. This relation is not so direct, however, since there is a lag in contamination of other foods compared to milk following Sr-90 deposition. The quarterly results for milk and other foods from New York shown in Figure 3 show quite clearly that the lag is about 1 quarter ( 3 months)。 Thus, the quarterly intake of $\mathrm{Sr}-90$ in milk should best be used as an indicator of the Sr-90 intake in other foods in the succeeding quarter.

$$
D_{i}=M_{i}+f \times M_{i-1}
$$

$$
\begin{aligned}
\mathrm{D}_{i}= & \text { total diet } \mathrm{Sr}-90 \text { intake in } i^{\text {th }} \text { quarter (pci) } \\
\mathrm{M}_{i}= & \mathrm{Sr}-90 \text { intake in milk in } i^{\text {th }} \text { quarter (pCi) } \\
\mathrm{f}= & \text { the factor relating quarterly intake of } \mathrm{Sr}-90 \text { in } \\
& \text { milk to the quarterly intake of } \mathrm{Sr}-90 \text { ir other } \\
& \text { foods in the following quarter. }
\end{aligned}
$$

It is seen from Figure 3 that the contribution from other foods to the total Sr-90 intake is greater than the milk con- 
tribution, except during the periods of heavy deposition in 1962-63 and in the spring of 1964. Thus even this method of estimation of Sr-90 intake must be adjusted when the deposition is particularly heavy.

Figure 6 shows, for the New York data, how the factor $f$ varied during the period $1960-70$ in relation to the total sr-90 deposition during the quarter. For low quarterly deposition $f$ varies from 0.8 to 2 , the average value for quarterly deposition less than $3 \mathrm{mCi} / \mathrm{km}^{2}$ being 1.4. Above 3 $\mathrm{mCi} / \mathrm{km}^{2}$ the factor decreases. For prediction purposes, a value of $\mathrm{f}=1.0$ for deposition from 3 to $5 \mathrm{mCi} / \mathrm{km}^{2}$ and $f=0.8$ for deposition $\geq 5 \mathrm{mCi} / \mathrm{km}^{2}$ would appear suitable.

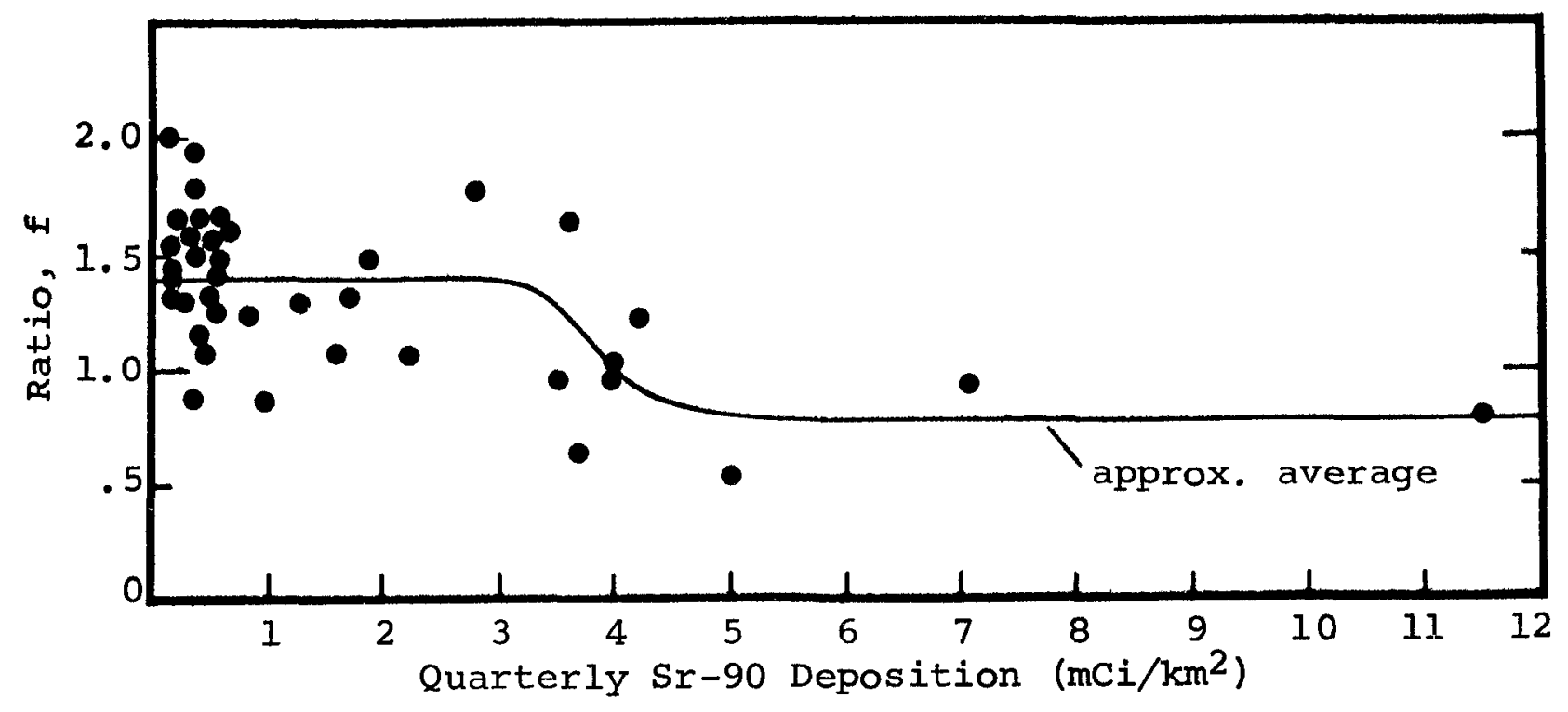

Fig. 6. Variation, relative to quarterly Sr-90 deposition, of the ratio of quarterly intake of $\mathrm{Sr}-90$ in other foods to that of milk in the previous quarter. 
The quarterly deposition, referred to Figure 6, has been shifted one month relative to the quarterly milk intake, since in comparing the deposition and milk records of Figures 1 and 2 , it is noted that peak deposition usually precedes peak levels in milk by about 1 month. Thus, for example, in using the first quarter milk intake (Jan., Feb., Mar.) to estimate second quarter intake of other foods (Apr., May, June), the choice of $f$ depends on the Sr-90 deposition in the first quarter shifted one month (Dec., Jan., Feb.). The one month shift in quarterly deposition is not too important, however, and it usually makes very little difference in the choice of $f$.

The estimation method may be summarized by the following relations:

Deposition

$$
\begin{aligned}
& <3 \frac{\mathrm{mCi}}{\mathrm{km}^{2} \cdot \mathrm{Qtr}} \quad \mathrm{D}_{i}=\mathrm{M}_{i}+1.4 \mathrm{M}_{i-1} \\
& 3-5 \frac{\mathrm{mCi}}{\mathrm{km}^{2} \cdot Q \mathrm{tr}} \quad \mathrm{D}_{i}=\mathrm{M}_{i}+1.0 \mathrm{M}_{\mathrm{i}-1} \\
& \geq 5 \frac{\mathrm{mCi}}{\mathrm{km}^{2} \cdot \mathrm{Qtr}} \quad \mathrm{D}_{i}=\mathrm{M}_{i}+.8 \mathrm{M}_{\mathrm{i}-1} \\
& \geq 5 \frac{\mathrm{mCi}}{\mathrm{km}^{2} \cdot \mathrm{Qtr}} \quad \mathrm{D}_{i}=\mathrm{M}_{i}+.8 \mathrm{M}_{\mathrm{i}-1} \\
& \mathrm{D}_{i}=\mathrm{Sr}-90 \text { intake in total diet in quarter } i \text { (pCi) } \\
& M_{i}=\operatorname{Sr}-90 \text { intake in milk in quarter } i \text { (pCi) }
\end{aligned}
$$


Using these relationships we may show in Figure 7 how the observed diet levels from 1960-70 are reproduced. The estimates of total diet intake obtained from the milk levels measured from 1954 to 1960 are also included in this figure. The dashed lines show the quarters in which the deposition was $>3 \mathrm{mCi} / \mathrm{km}^{2}$, thus requiring adjustment in the factor $\mathrm{f}$. The solid lines above the dashed lines show the overestimate obtained if the factor is not adjusted. Even without adjustment, the yearly intake estimated on this quarterly basis is within $25 \%$ of the observed values. The adjusted quarterly total diet $\mathrm{Sr}-90$ intake estimates are quite close to the observed results for the entire sampling period.

In terms of the $\mathrm{Sr}-90 / \mathrm{Ca}$ ratios in diet and milk, the estimation formula for deposition $<3 \mathrm{mCi} / \mathrm{km}^{2} \cdot \mathrm{Qtr}$ becomes (based on $386 \mathrm{gCa} / \mathrm{yr}$ in diet and $222.6 \mathrm{gCa} / \mathrm{yr}$ in $\mathrm{milk}$ ):

$$
\begin{aligned}
& \text { Quarterly } \quad \mathrm{D}_{\mathrm{i}}=.6 \mathrm{M}_{\mathrm{i}}+.8 \mathrm{M}_{\mathrm{i}-1} \\
& \text { Yearly } \quad \mathrm{D}_{\mathrm{n}}=\frac{1}{4}\left\{.8 \mathrm{M}_{0}+1.4\left(\mathrm{M}_{1}+\mathrm{M}_{2}+\mathrm{M}_{3}\right)\right. \\
& \\
&
\end{aligned}
$$

When $\mathrm{M}_{0}$, the $\mathrm{Sr}-90 / \mathrm{Ca}$ ratio in milk in the $4^{\text {th }}$ quarter of the year $n-1$, is equal to $M_{4}$, the ratio in the $4^{\text {th }}$ quarter of the year $n$, that is when milk levels are unchanging, 


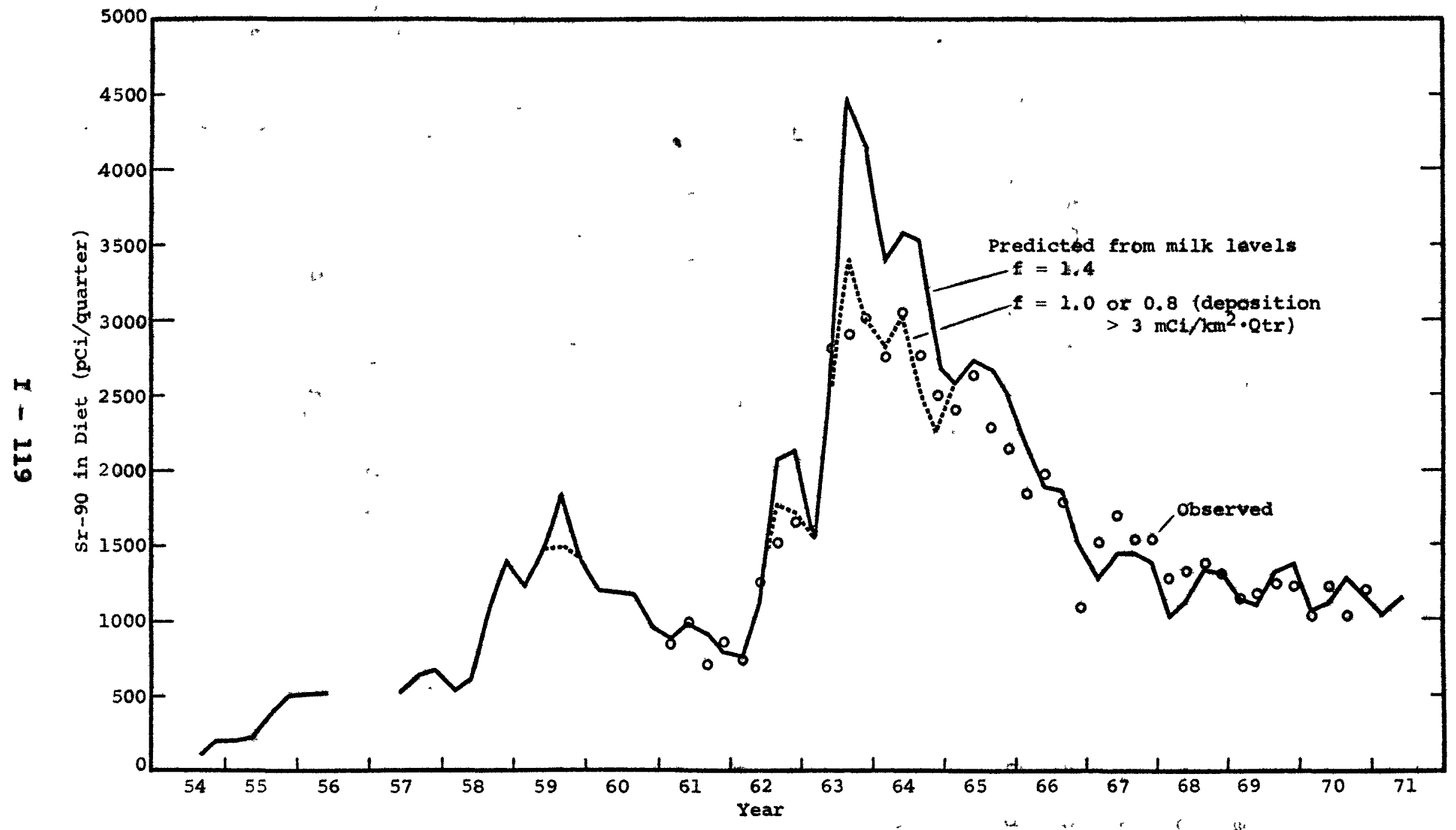

Fig. 7. Quarterly Sr-90 intake in total diet in New York City. 


$$
\mathrm{D}_{\mathrm{n}}=1.4 \mathrm{M}
$$

where $D_{n}$ and $M_{n}$ are the average $\mathrm{Sr}-90 / \mathrm{Ca}$ ratios in the diet and in milk in the year $n$.

This, of course, brings us back to the use of the average diet-milk ratio, but only when the deposition is low. In periods of heavy $\mathrm{S} r-90$ deposition, the dietary $\mathrm{S} r-90$ intake estimates should be adjusted, as discussed above, and, if Sr-90 levels in milk are changing, quarterly estimation of dietary $\mathrm{Sr}-90$ intake is recommended.

\section{Conclusion}

The long-term sampling programs conducted by this laboratory have permitted quite good correlation of Sr-90 fallout deposition with the Sr-90 levels in milk and have indicated a relationship between $\mathrm{Sr}-90$ intake in milk and in total diet which should allow projections or estimates of Sr-90 intake, where sampling is not as complete, to be made with confidence.

The estimation techniques have been derived from the New York data, but the methods should be generally applicable. The parameters for other areas might be expected to vary slightly because of different soil conditions and pasturing practices and also differences in diets. In instances where 
the data is less localized, such as country-wide survey measurements, some loss of detail might be expected.

Brief investigation of the diet and milk data variously reported from other countries has also shown variations of the diet-milk ratio with time. In most areas the ratio decreases, as would be expected, during the 1962-64 heavy fallout period. Those countries that no longer analyze total diet or that have traditionally analyzed only milk may wish to consider some adjustment of the diet-milk ratio to account for its nonconstant nature. When adjustment of the diet-milk ratio is undertaken, or even when it is not, better estimates of dietary Sr-90 intake are obtained when quarterly results from milk programs are used in the manner described above.

\section{References}

1. Tajima, E。

Report of the Scientific Committee on the Effects of Atomic Radiation

Supplement No. 17 (A/3838) (1958)

2. O'Brien, B. J. Private communication

3. Bartlett, B. O.

An Improved Relationship between the Deposition of Strontium-90 and the Contamination of Milk in the United Kingdom ARC, Letcombe Labcratory Annual Report 1970 (1971) 
4. Hvinden, $T$. and Lillegraven, $A$.

Cesium-137 and Strontium-90 in Norwegian Milk 1960-1969 Norwegian Defence Research Establishment, Intern rapport F-539 (1970)

5. Van der Stricht, E., Gaglione, P. and de Bortoli, M. Predictions of ${ }^{90} \mathrm{Sr}$ Levels in Milk on the Basis of Deposition Values

Second Int. Congress I.R.P.A., Brighton (1970)

6. Bennett, B. G.

Strontium-90 in the Diet - Results through 1970

USAEC Report HASL-242, April (1971) 
PART II

HASL FALLOUT PROGRAM DATA

$+$

$I I-1$ 
1. Fallout Deposition

1.1 Monthly Precipitation

1.11 Sr90 and $\mathrm{Sr}^{89}$ in Monthly Deposition at World Land Sites

Precipitation and dry fallout are collected over monthly periods at stations in the United States and overseas. The samples are analyzed for $\mathrm{Sr} 90_{\text {, }}$ and $5 r 89$ whenever possible. A description of the sampling network and available data for each site are given in the Appendix. Section A.

1.12 Other Isotopes at Selected Sites

At a number of stations in the United States, monthly deposition collections were analyzed for radiostrontium and other nuclides of interest to the Atomic Energy Commission. Multinuclide analyses were discontinued as of July 1967 and the complete data reported in HASL-193, p. II-4 thru II-25.

Plutonium analyses of monthly deposition were carried out at New York City, Melbourne, Seattle, Honolulu, Salisbury, Durban, and Rio de Janeiro. This program has been terminated and the complete data are given in HASL-237 on pages II-4 thru II-13.

1.2 $\mathrm{Sr}^{90}$ and $\mathrm{Sr}^{89}$ Deposition at Atlantic Ocean Weather Stations

Measurements of radiostrontium in precipitation and dry fallout collections at four U. S. Coast Guard Stations in the North Atlantic Ocean are carried out for comparison with land stations in the same latitude band. A description of the stations and available data are given in the Appendix. Section B.

\section{Surface Air Sampling Program}

The Health and Safety Laboratory has been collecting surface air particulate samples at stations in the Western Hemisphere since January 1963. The filters are analyzed for a number of fission and activation product radionuclides as well as stable lead. A description of the program and available data are given in the Appendix, Section C. 
3. Project Airstream

The Health \& Safety Laboratory measures radioactivity in the lower stratosphere employing the $\mathrm{RB}-57 \mathrm{~F}$ aircraft as a sampling platform. The aircraft are flown by the 58 th Weather Reconnais= sance Squadron under the direction of the 9 th Weather wing of the Air Weather Service. The missions are scheduled quarterly and the coverage extends from $75^{\circ} \mathrm{N}$ to $51^{\circ} \mathrm{S}$ latitude in the Western Hemisphere. Air filter samples are collected from 12 to $19 \mathrm{~km}$ altitude and analyzed for a number of radionuclides. A more complete description of the program and available data are given on pages II-8 to II-36 of HASL-245.

4. High Altitude Balloon Sampling Program

Balloon borne filtering devices are used to collect nuclear debris at altitudes from $21-32 \mathrm{~km}$. Balloon launchings are conducted annually at Fairbanks, Alaska, $65^{\circ} \mathrm{N}$; Sioux City。 Iowa $42^{\circ} \mathrm{N}$; Alamagordo, N.M., $33^{\circ} \mathrm{N}$; and Panama C.Z., $9^{\circ} \mathrm{N}$ and quarterly at Mildura, Australia, $34^{\circ} \mathrm{S}$. Filters are analyzed for a number of radionuclides. A more complete description of the program and available data are given on pages II-37 to II-93 of HASL-245.

5. Radiostrontium in Milk and Tap Water

Sr90 levels in both powdered and fresh milk distributed in New York City and tap water sampled at the Health \& Safety Laboratory, have been measured on a monthly basis since 1954. These data are summarized in tabular and graphical form in the Appendix. Section D.

6. Strontium 90 in Diets

Quarterly estimates of the annual dietary intake of $\mathrm{sr} 90$ of New York City and San Francisco residents have been made based on analyses of foods purchased at these cities every three months since 1960. Sampling in Chicago was discontinued in 1967. The program is described and available data reported on p. II-4 to II -6 of this report.

7. UNSCEAR - WHO Bone Program

Available Sr90 data for human bone samples collected in 1969. 1970, and 1971 from countries in Latin America, Africa, and Asia are presented on pages II-4 to II-7 of HASL-245.

8. Sr $^{90}$ in Human Bone - 1970 Results

Specimens of human vertebrae from New York City and San Francisco have been made available for $\mathrm{Sr} 90$ analysis since 1961. The results for 1970 are evaluated beginning on page I-99 of HASL-243. 
6. HASL Diet Studies: Second Quarter 1971

Results of the measurements of the $s 9^{90}$ content of foods purchased in New York City and San Francisco in the second quarter of 1971 are given in the following table. Estimates of the daily intake of $\mathrm{sr}^{90}$ based on these measurements and on the revised consumption statistics given in the most recently available U. S. Department of Agriculture Report (1), are also listed.

The estimates of daily $\mathrm{Sr}^{90}$ intake are a continuation of the HASL Tri-City diet studies which were started in March of 1960 . Results of the earlier measurements along with those made during 1970 are shown graphically in the figure on page II-6. A complete description of the sampling methods and philosophy of the HASL diet studies was given in HASL-147)2). A discussion of the reasons for changes in the Tri-City diet studies made in 1968 was given in HASL-200 (3)。

\section{REFERENCES}

(1) Food Consumption of Households in the United States Spring 1965

A Preliminary Report, U.S.D.A. ARS 62-16, August 1967

(2) Rivera, J. and Harley, J H HASL Contributions to the Study of Fallout in Food Chains USAEC Report HASL-147, July (1964)

(3) USAEC Report HASL-200, October (1968), p. II-6

$$
\text { II }-4
$$


STRONTIUM 90 IN NEW YORK CITY AND SAN FRANCISCO DIETS - Second Quarter 1971 -

$\%$ of

yearly

intake

Diet Category

DAIRY PRODUCTS

$\mathrm{kg} / \mathrm{yr}$

$\mathrm{gCa} / \mathrm{yr}$ of $\mathrm{Ca}$

FRESH VEGETABLES

CANNED VEGETABLES

ROOT VEGETABLES

POTATOES

DRY BEANS

216.0

58

NEW YORK CITY - MAY

$\%$ of

pCi sr90 pCi $\frac{\mathrm{sr} 90}{\mathrm{Kr}} \quad$\begin{tabular}{l}
$\begin{array}{l}\text { yearly } \\
\text { intake } \\
\text { of } \mathrm{sr} 90\end{array}$ \\
\hline $\mathrm{kg}$
\end{tabular}

$9.3 \quad 1860$

19.0

9

FRESH FRUIT

CANNED FRUIT

FRUIT JUICES

110.6

$H$

BAKERY PRODUCTS

FLOUR

WHOLE GRAIN PRODUCTS

MACARONI

RICE

$\begin{array}{rr}44 & 53.7 \\ 34 & 6.5 \\ 11 & 10.3 \\ 3 & 0.6 \\ 3 & 1.1\end{array}$

3

1.6

3.5

7.7

13.2

4.5

1.9

20

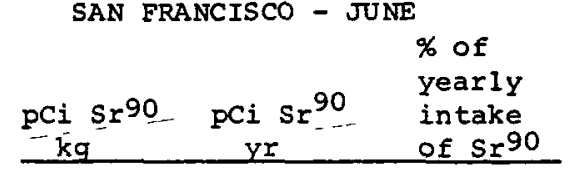

$2.9 \quad 583$

$\begin{array}{lrr}\text { MEAT } & 79 & 12.6 \\ \text { POULTRY } & 20 & 6.0 \\ \text { EGGS } & 15 & 8.7 \\ \text { FRESH FISH } & 8 & 7.6 \\ \text { SHELLFISH } & 1 & 1.6\end{array}$

10

370

5039

13.6
37

2.3

6.3

6.8

8.4

14.2

18
99

8.5

50

63

259

25

26

2.0

3.1

3.3

0.6

17.2

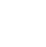

95

68

52

\section{6}

1.7

2.8

19

372

263

145

14

36

16

$\begin{array}{rr}3.8 & 166 \\ 4.9 & 166 \\ 6.5 & 71 \\ 3.6 & 11 \\ 2.4 & 7\end{array}$

16

$\begin{array}{rr}0.6 & 48 \\ 0.9 & 19 \\ 2.2 & 33 \\ 1.2 & 10 \\ 1.1 & 1\end{array}$

0.7
1.1
2.3
0.3
0.4

2
15

151

19
79

166

11
7

7
YEARLY INTAKE

DAILY INTAKE = pCi per gCa

1632

4.4 


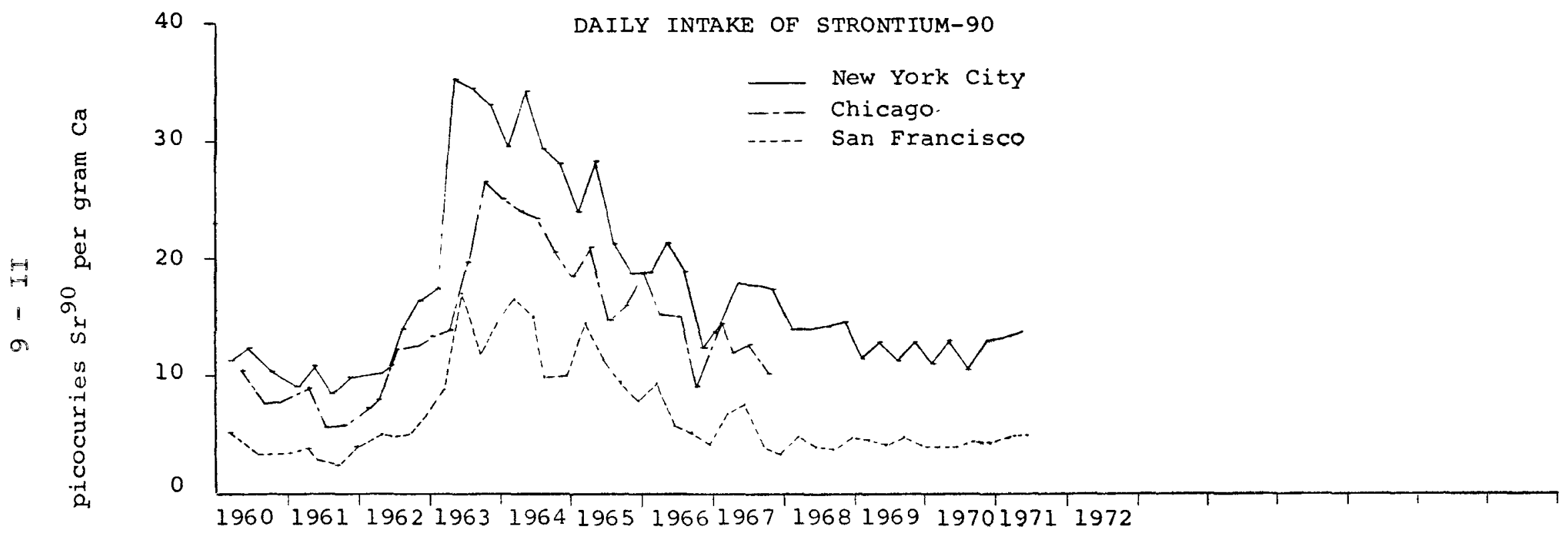




\section{PART III}

\section{DATA FROM SOURCES OTHER THAN HASL}

Numerous fallout studies are conducted by other organizations in the United States and abroad. Some of these are sent to the editors for dissemination in these HASL Quarterly Reports. Submitted data are reproduced essentially as received and no interpretation by HASL is attempted.

1. EURATOM Joint Nuclear Research Centre III-2 Ispra Establishment, Protection Service Site Survey and Meteorology Section, Quarterly Report

2. Radiological Physics Division, Argonne III-7 National Laboratory Cesium-137 in Various Chicago Foods (Collection Month, October 1971) by S. S. Brar and D. M. Nelson

3. Global Atmospheric Radioactivity: January 1970 
EURATOM JCINT NUCLEAR RESEARCH CENTRE

ISPRA ESTABLISHMIENT

Protection Service

Site Survey and Meteorology Section

QUARTERLY REPORT

EUR/C-IS/394/70e. 
The Euratom Ispra Establishment is located in Northern Italy

$58 \mathrm{Km} \mathrm{NW}$ from Niilan and $14 \mathrm{Km}$ W from Varese.

The activity levels shown in this report represent world wide fallout, and do not reflect any contamination from the site.

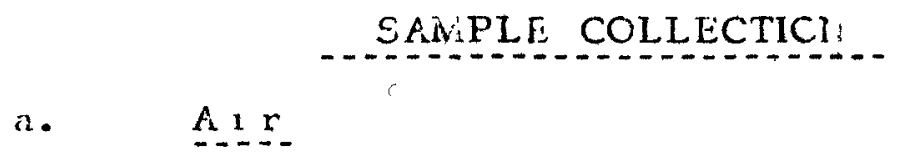

Air is Jrawn by pumps through paper filters at the rate of, at least, $500 \mathrm{~m}^{3} /$ day, measured by gas mater.

The single daily filters are measured for gross beta radioactivity and then pooled to give monthly samples, for gamma spectrometry and radiochemical cinaiyses.

Ł. Wet and dry deposition

These samples are collected monthly ty means of four $1 \mathrm{~m}^{2}$ stainless steel funnels, with the bottom always covered with deionized water. Water in excess of a pre-fixed level drains through a filter and a double (cationic and anionic) ion-exchange column. The eluate of the resins and the filters are sutmitted to the analyses. This procedure is described in detail in the paper by iv. C. de Bortoli and P. Gaglione : "Sampling of radioactive deposition through ion-exchange resins", Giornale di Fisica Sanitaria, 13, 219-224 (1969).

$$
\text { c. } \quad \text { ivi i } 1 \mathrm{k}
$$

Ivilk is collected twice a week in four small local dairies to give 8 liters/month. About six liters arr dried and submitted to gamma spectrometry and two liters ashed for radıochemical determination of strontium-90. 
a. Strontium-90 is separated by the fuming nitric acid precipitation and then purified through hydroxides and chromates precipitations. The activity of the final strontium carbonate and yttrium oxalate precipitates is measured in low level anticoincidence beta counters.

b. Cesium-137 is measured by dircct gamma spectrometry on the unprocessed or dried samples and, whenever it is necessary, by gamma spectrometry after chemical separation. This is performed by filtration of the solution, obtained dissolving the sample, through a thin AMP (ammonium molybdophosphate) layer, by which cesium is retained. Details of this procedure may be found in the paper by I. Van der Stricht issued on "Radiochimica Acta" $\underline{3}, 193-199$ (1964).

c. Gamma emitting nuclides are measured by direct gamma spectrometry, using, also the spectrum stripping technique.

d. Plutonium isotopes are separated by anion exchange and electrodeposition; details of the procedure may be found in the paper by M. C. de Bortoli : "Radiochemical determination of plutonium in soil and other environmental samples", Anal. Chem. 39, 375 (Niarch 1967).

The activity is measured in a Frish grid ionisation chamber connected to a multichannel analyser.

EXTRAPOLATION OF THE DATA

Except when otherwise stated, the data presented in this report are extrapolated to the last day of the collecting period.

EUR/C-IS/394/70€. 


\section{AIR RADIOACTIVITY}

1971

SITE : I S P R A

LAT $44^{\circ} 49^{\prime} \mathrm{N}$

IONG. $8^{\circ} 37^{\prime} \mathrm{E}$

AIT $.250 \mathrm{~m}$

\begin{tabular}{|c|c|c|c|c|c|c|}
\hline Month & $\begin{array}{c}\text { Gross beta } \\
\mathrm{pCi} / \mathrm{m}^{3}\end{array}$ & $\begin{array}{l}90 \mathrm{Sr} \\
10^{-3} \mathrm{pCi} / \mathrm{m}^{3}\end{array}$ & $\begin{array}{c}{ }^{89} \mathrm{Sr} \\
10^{-3} \mathrm{pCi} / \mathrm{m}^{3}\end{array}$ & $\begin{array}{l}{ }^{137} \mathrm{Cs} \\
10^{-3} \mathrm{pCi} / \mathrm{m}^{3}\end{array}$ & $\begin{array}{c}{ }^{239} \mathrm{Pu} \\
10^{-5} \mathrm{pCi} / \mathrm{m}^{3}\end{array}$ & $\begin{array}{l}238 \mathrm{Pu} \\
10^{-5} \mathrm{pCi} / \mathrm{m}^{3}\end{array}$ \\
\hline & & & & & & \\
\hline June & 0.68 & 5.5 & 27 & 8.4 & 12 & 0.66 \\
\hline July & 0.70 & 6.6 & 19 & 9.0 & 12 & 0.62 \\
\hline August & 0.41 & 4.0 & 4.5 & 6.1 & 6.1 & 0.34 \\
\hline September & 0.21 & 1.7 & 1.5 & 2.6 & - & - \\
\hline
\end{tabular}

- Data not yet available 
FALLOUT DEPOSITION

\section{1}

SITE : I S P R A

LAT. $45^{\circ} 49^{\prime} \mathrm{N}$

LONG. $8^{\circ} 37^{\circ} \mathrm{E}$

ALT. $250 \mathrm{~m}$

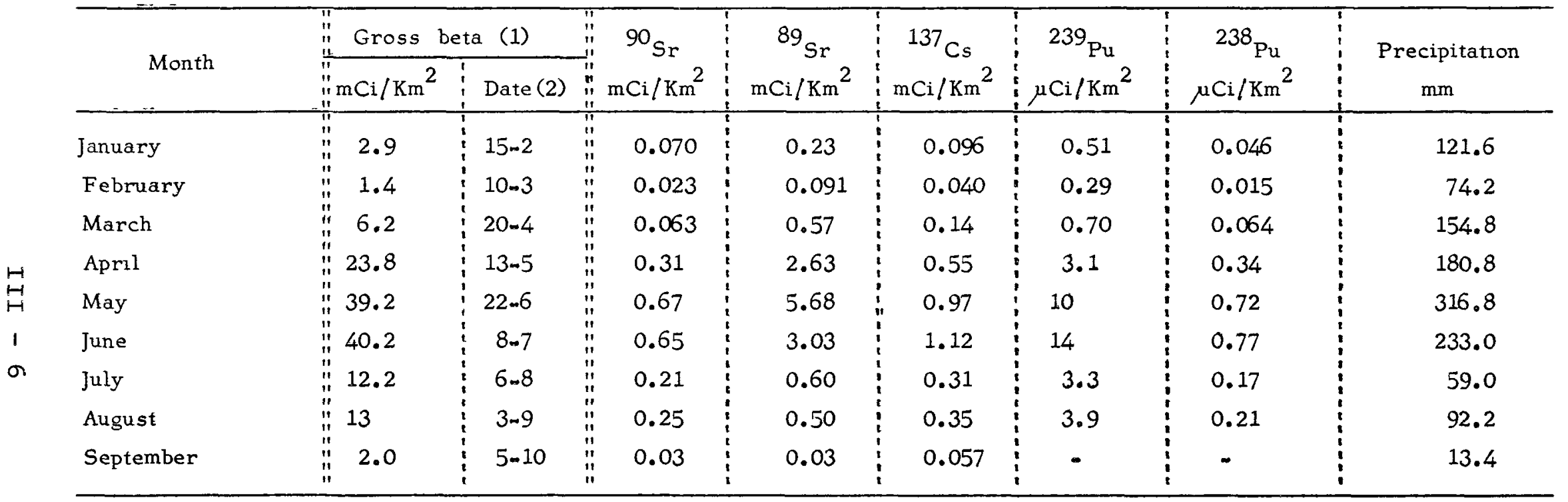

(1) Potassium -40 equivalent $\left(40 \mathrm{mg} / \mathrm{cm}^{2}\right)$.

(2) Day and month of the gross beta measurement.

- Data not yet available. 


\title{
Cesium-137 in Various Chicago Foods * \\ (Collection Month October, 1971)
}

\author{
S. S. Brar and D. M. Nelson \\ Radiological Physics Division \\ Argonne National Laboratory \\ Argonne, Illinols 60439
}

Since April, 1961, the ${ }^{137} \mathrm{Cs}$ and potassium content of the Chicago portion of Tri-City Diet Sampling Program has been determined ${ }^{1-4}$ in bulk food samples by gamma ray spectrometry using a 4" x 4" NaI (Tl) crystal. The individual food components were counted for a minimum of 100 minutes, and from these measurements composite daily and yearly food intakes were obtained. Cesium-137 activity in food, now, is an order of magnitude lower than it was a few years ago; consequently, a new procedure for these measurements has been adopted in order to improve accuracy. The same variety of foods (all fresh vegetables, all fresh fruits, etc.) are composited before measurement, and the samples are counted a minimum of 400 minutes. The results for the October, 1971 quarter are tabulated in Tables I and II.

*Work performed under the auspices of the U. S. Atomic Energy Commission. 
Table 1

Cesium-137 in Chicago Diets

(Adults)

October, 1971

\begin{tabular}{|c|c|c|c|c|c|}
\hline & $\mathrm{kg} / \mathrm{yr}$ & $\begin{array}{c}\text { Potassium } \\
\mathrm{g} / \mathrm{kg}\end{array}$ & $\begin{array}{l}{ }^{137} \mathrm{Cs} \\
\mathrm{pCi} / \mathrm{kg}\end{array}$ & $\begin{array}{c}\text { Potassium } \\
\mathrm{g} / \mathrm{yr}\end{array}$ & $\begin{array}{l}{ }^{137} \mathrm{Cs} \\
\mathrm{pCi} / \mathrm{yr}\end{array}$ \\
\hline White Bread & 37 & 1.4 & 22 & 52 & 814 \\
\hline Whole Wheat Bread & 11 & 2.6 & 37 & 29 & 407 \\
\hline Eggs & 16 & 1.4 & 0 & 22 & 0 \\
\hline Fresh Vegetables & 43 & 3.9 & 0 & 168 & 0 \\
\hline Root Vegetables & 17 & 2.9 & 0 & 49 & 0 \\
\hline Milk & 221 & 1.5 & 9 & 332 & 1989 \\
\hline Poultry & 17 & 2.5 & 10 & 43 & 170 \\
\hline Fresh Fish* & 8 & 3.0 & 3.2 & 24 & 256 \\
\hline Flour & 43 & 1.1 & 28 & 47 & 1204 \\
\hline Macaroni & 3 & 2.0 & 3.0 & 6 & 90 \\
\hline Meat & 73 & 2.9 & 19 & 212 & 1387 \\
\hline Dried Beans & 3 & 11.8 & 20 & 35 & 60 \\
\hline Fresh Fruit & 68 & 1.9 & 6 & 129 & 408 \\
\hline Potatoes & 45 & 4.2 & 0 & 189 & 0 \\
\hline Canned Fruits & 26 & 0.9 & 9 & 23 & 234 \\
\hline Canned Fruit Juices & 19 & 1.6 & 12 & 30 & 228 \\
\hline Canned Vegetables & 20 & 0.7 & 8 & 14 & 160 \\
\hline Total/yr & & & & 1404 & 7407 \\
\hline Total/day & & & & 3.8 & 20 \\
\hline
\end{tabular}

*It is assumed in arriving at the average that nine times more ocean fish is consumed than fresh water fish. 
Table II

Cesium-137 in Chicago Diets

(Infants)

October, 1971
Evaporated Milk

Formula Milk

Cereals

Fruits

Meats

Vegetables

Total/yr

Total/day
${ }^{137} \mathrm{Cs}$ $\mathrm{pCi} / \mathrm{kg}$

31

15

23

10

42

2.1
Potassium

$\mathrm{g} / \mathrm{yr}$

411

70

22

18

39

48

608

1.7
${ }^{137} \mathrm{Cs}$ $\mathrm{pCi} / \mathrm{yr}$

4247

555

184

230

714

0

5930

16 


\section{References}

1. S. S. Brar, et al., USAEC Report No. HASL-146, Cs-137 in Various Chicago Diets, pp. 225-232, July 1, 1964.

2. J. Rivera and J. J. Kelly, USAEC Report No. HASL-144, Cs-137 in Tri-City Diets, pp. 228, April 1, 1964.

3. J. Rivera and J. H. Harley, USAEC Report No. HASL-147, Contributions to the Study of Fallout in Food Chains, pp. 31-35, July, 1964.

4. S. S. Brar and D. M. Nelson, USAEC Report No. HASL-245, Cs-137 in Various Chicago Foods, pp. III-25 to III-28, October 1, 1971. 


\section{GLOBAL ATMOSPHERIC RADIOACTIVITY}

\section{JANUARY 1970}

\section{Introduction}

In January 1970, USAF aircraft were deployed to make a series of vertical profiles of particulate radioactivity in the atmosphere. Aircraft sampling was normally conducted in the vicinity of four latitudes: $70^{\circ} \mathrm{N}, 35^{\circ} \mathrm{N}, 10^{\circ} \mathrm{N}$, and $40^{\circ} \mathrm{S}$. Altitudes sampled varied from approximately $12.2 \mathrm{~km}(40,000$ feet $)$ to about $20.1 \mathrm{~km}(66,000$ feet $)$. Radiochemical analysis was by government laboratories.

These data were collected as part of a cooperative effort by the U.S. Department of Defense, Atomic Energy Commission and National Oceanic and Atmospheric Administration, and are a continuation of similar sampling programs conducted in the past (1-8).

\section{Data}

A summary of the data is given in the tables.

$\begin{array}{ll}\text { Date } & \begin{array}{l}\text { Date (GCT) on which the filter was } \\ \text { extracted from the aircraft, immediately } \\ \text { after landing. }\end{array} \\ \text { Altitude } & \begin{array}{l}\text { Pressure altitude (in kilometers) at which } \\ \text { sampling was performed. }\end{array} \\ \text { Tropopause } & \begin{array}{l}\text { Height of tropopause (In kilometers) as } \\ \text { reported by a nearby radiosonde station. }\end{array} \\ \begin{array}{c}\text { Isotopic } \\ \text { data }\end{array} & \begin{array}{l}\text { All data are reported in units of pico- } \\ \text { curies per } 100 \text { standard cubic meters of }\end{array} \\ & \text { alr. All radioactivity data are corrected }\end{array}$


for decay to day of extraction of the filter. The following constants were used:

\begin{tabular}{|c|c|c|}
\hline Isotope & $\begin{array}{l}\text { Half-1ife } \\
\text { Days } \\
\end{array}$ & $\begin{array}{l}\text { Decay Constant } \\
\text { Days }-1 \\
\end{array}$ \\
\hline $\begin{array}{l}\mathrm{Be}-7 \\
\mathrm{Mn}-54 \\
\mathrm{Fe}-55 \\
\mathrm{Sr}-89 \\
\mathrm{Sr}-90\end{array}$ & $\begin{array}{c}53.0 \\
309 \\
1073 \\
53.0 \\
10104\end{array}$ & $\begin{array}{l}0.0131 \\
0.00224 \\
0.000646 \\
0.0131 \\
0.0000686\end{array}$ \\
\hline $\begin{array}{l}\text { Zr-95 } \\
\text { Cs-137 } \\
\text { Ba-140 } \\
\mathrm{Ce}-141 \\
\mathrm{Ce}-144\end{array}$ & $\begin{array}{c}63.6 \\
9708 \\
12.8 \\
32.5 \\
282\end{array}$ & $\begin{array}{l}0.0109 \\
0.0000714 \\
0.0542 \\
0.0213 \\
0.00246\end{array}$ \\
\hline $\begin{array}{l}\mathrm{Pb}-210 \\
\mathrm{Pu}-238 \\
\mathrm{Pu}-239\end{array}$ & $\begin{array}{r}8030 \\
31500 \\
8800000\end{array}$ & $\begin{array}{l}0.0000863 \\
2.2 \times 10^{-5} \\
7.8 \times 10^{-8}\end{array}$ \\
\hline \multicolumn{3}{|c|}{$\begin{array}{l}\text { Unless otherwise indicated, the precision } \\
\text { of the radiochemical analysis is within } \\
3 \% \text { Standard errors in the analysis greater } \\
\text { than } 3 \% \text { are indicated by a lower case letter } \\
\text { following the value in accordance with the } \\
\text { following code: }\end{array}$} \\
\hline
\end{tabular}

$\begin{array}{cc}\text { a } & 3-10 \% \\ \text { b } & 11-20 \% \\ \text { c } & 21-40 \% \\ \text { d } & 41-100 \% \\ \text { e } & >100 \%\end{array}$

NR indicates the isotope was not detected in resolvable amounts. 


\section{Acknowledgments}

This program would not have been possible without the cooperation of the Government of Argentina.

\section{References}

1. Fallout Program, Quarterly Summary Report, Health and Safety Laboratory New York Operations Office, U.S.A.E.C., HASL-115, October 1, 1961, pp. 177-183.

2. , HASL-117, December 30, 1961, pp. 225-229.

3. , HASL-142, January 1, 1964, PP. 272-276.

4. , HASL-165, January 1, 1966, pp. 301-311.

5. , HASL-172, July 1, 1966, pp. 164-171.

6. , HASL-182, July 1, 1967, pp. III30-III47.

7. , HASL-214, October 1, 1969, pp. III12-III43.

8. HASL-227, Ju1y 1, 1970, pp. III12-III21. 
Atmospheric Radioactivity Data, January 1970

\begin{tabular}{|c|c|c|c|c|c|}
\hline Latitude & $70-75^{\circ} \mathrm{N}$ & $70-75^{\circ} \mathrm{N}$ & $70-75^{\circ} \mathrm{N}$ & $67-70$ & $70-75^{\circ} \mathrm{N}$ \\
\hline Long I tude & $144^{\circ} \mathrm{W}$ & $144^{\circ} \mathrm{W}$ & $144^{\circ} \mathrm{W}$ & $144^{\circ} \mathrm{W}$ & $143^{\circ} \mathrm{W}$ \\
\hline Date & 13 & 20 & 13 & 13 & 12 \\
\hline Altitude $(\mathrm{km})$ & 12.2 & 12.2 & 15.2 & 15.2 & 18.3 \\
\hline $\begin{array}{l}\text { Tropopause Ht. } \\
(\mathrm{km})\end{array}$ & $8.5-9.1$ & $8.2-9.4$ & $9.5-10.6$ & $8.5-9.1$ & $9.5-10.6$ \\
\hline \multicolumn{6}{|l|}{ Isotopes } \\
\hline $\mathrm{Be}-7$ & 5850 & 2890 & 4660 & 19000 & 14700 \\
\hline$M n-54$ & $8.9 a$ & $10 a$ & 31 & 63 & $13 a$ \\
\hline $\mathrm{Fe}-55$ & $32 b$ & - & $\cdots$ & $190 \mathrm{a}$ & -- \\
\hline Sr-89 & 1160 & 1770 & 8380 & 11300 & 5240 \\
\hline Sr -90 & 56 & $100 a$ & $235 b$ & 274 & $183 a$ \\
\hline$z r-95$ & 2120 & 3320 & 15700 & 20500 & 9950 \\
\hline Cs-137 & 97 & 82 & 278 & 509 & 272 \\
\hline$B a-140$ & $177 \mathrm{~b}$ & 161 & 999 & 1640 & 688 \\
\hline $\mathrm{Ce}-141$ & - & 1940 & 9210 & - & 6370 \\
\hline $\mathrm{Ce}-144$ & 1370 & 2210 & 7930 & 12900 & 5170 \\
\hline $\mathrm{Pb}-210$ & 0.93 & $<0.3$ & $<0.7$ & $0.61 a$ & $<0.8$ \\
\hline $\mathrm{Pu}-238$ & $0.17 \mathrm{a}$ & $0.23 a$ & $0.35 a$ & $0.39 a$ & $0.30 a$ \\
\hline $\mathrm{Pu}-239$ & 0.69 & 0.99 & 2.6 & 3.5 & 1.7 \\
\hline
\end{tabular}


Atmospheric Radloactivity Data, January 1970

\begin{tabular}{|c|c|c|c|c|c|}
\hline Latitude & $66-70^{\circ} \mathrm{N}$ & $70-75^{\circ} \mathrm{N}$ & $70-75$ & $30-35^{\circ} \mathrm{N}$ & $30-35^{\circ} \mathrm{N}$ \\
\hline Longltude & $145^{\circ} \mathrm{W}$ & $144^{\circ} \mathrm{W}$ & $144^{\circ} \mathrm{W}$ & $103-107^{\circ} \mathrm{W}$ & $103-106^{\circ} \mathrm{W}$ \\
\hline Date & 19 & 5 & 12 & 6 & 20 \\
\hline Altitude (km) & 18.3 & 18.9 & 18.9 & 12.2 & 12.2 \\
\hline $\begin{array}{l}\text { Tropopause Ht. } \\
\text { (km) }\end{array}$ & $9.1-9.8$ & $6.8-11.0$ & $9.5-10.6$ & 10.7 & 12.2 \\
\hline \multicolumn{6}{|l|}{ Isotopes } \\
\hline $\mathrm{Be}-7$ & 4340 & .7530 & 25400 & 6460 & 818 \\
\hline$M n-54$ & 21 & 13 & 21 & $3.8 \mathrm{a}$ & $<0.8$ \\
\hline $\mathrm{Fe}-55$ & $75 a$ & $33 a$ & -- & -- & $<6$ \\
\hline$S r-89$ & 2930 & 2070 & 2780 & 493 & 25 \\
\hline Sr-90 & 114 & 67 & $92 a$ & $42 a$ & 2.6 \\
\hline $\mathrm{Zx}-95$ & 5260 & 3590 & 5170 & 914 & 68 \\
\hline Cs-137 & 179 & 89 & 132 & 67 & 4.1 \\
\hline $\mathrm{Ba}-140$ & $254 a$ & $331 a$ & 362 & $74 a$ & NR \\
\hline $\mathrm{Ce}-141$ & -- & -- & 3310 & 547 & -- \\
\hline $\mathrm{Ce}-144$ & 3660 & 2030 & 2780 & 785 & 39 \\
\hline $\mathrm{Pb}-210$ & $0.29 b$ & $0.17 c$ & $<1$ & $<0.2$ & $0.24 b$ \\
\hline $\mathrm{Pu}-238$ & $0.35 a$ & $0.26 a$ & $0.30 a$ & $0.12 \mathrm{a}$ & $0.02 \mathrm{C}$ \\
\hline $\mathrm{Pu}-239$ & 1.1 & 0.72 & 0.97 & 0.44 & 0.04 \\
\hline
\end{tabular}


Atmospheric Radioactivity Data, January 1970

\begin{tabular}{|c|c|c|c|c|c|}
\hline Latitude & $30-35^{\circ} \mathrm{N}$ & $30-35^{\circ} \mathrm{N}$ & $30-35^{\circ} \mathrm{N}$ & $30-35^{\circ} \mathrm{N}$ & $30-35^{\circ} \mathrm{N}$ \\
\hline Long itude & $103-107^{\circ} \mathrm{W}$ & $102-106^{\circ} \mathrm{W}$ & $103-106^{\circ} \mathrm{W}$ & $103-106^{\circ} \mathrm{W}$ & $103-107^{\circ} \mathrm{W}$ \\
\hline Date & 5 & 12 & 5 & 19 & 12 \\
\hline Altitude $(\mathrm{km})$ & 15.2 & 15.2 & 18.3 & 18.3 & 19.2 \\
\hline $\begin{array}{l}\text { Tropopause Ht. } \\
(\mathrm{km})\end{array}$ & $9.4-12.8$ & $10.1-10.7$ & $9.4-12.8$ & $11.0-11.3$ & $10.1-10.7$ \\
\hline \multicolumn{6}{|l|}{ Isotopes } \\
\hline $\mathrm{Be}-7$ & 6670 & 2600 & 7770 & 9080 & 8960 \\
\hline$M n-54$ & 11 & $1.9 \mathrm{a}$ & $19 a$ & 36 & 31 \\
\hline $\mathrm{Fe}-55$ & -- & $6.5 b$ & -- & $106 a$ & -- \\
\hline Sr -89 & 2670 & 197 & 5360 & 5770 & 8500 \\
\hline Sr -90 & 97 & 11 & 181 & 197 & $302 a$ \\
\hline Zr-95 & 5190 & 352 & 9700 & 10300 & 16000 \\
\hline Cs -137 & 157 & 19 & 290 & 287 & $393 a$ \\
\hline $\mathrm{Ba}-140$ & $532 a$ & 32 & 1090 & $2120 a$ & 1120 \\
\hline $\mathrm{Ce}-141$ & 3560 & -- & $6040 a$ & -- & 10600 \\
\hline $\mathrm{Ce}-144$ & 2690 & 473 & $5000 a$ & 6060 & 8370 \\
\hline $\mathrm{Pb}-210$ & $<0.3$ & 0.76 & $<0.8$ & $0.79 b$ & $<1$ \\
\hline $\mathrm{Pu}-238$ & $0.21 a$ & $0.07 a$ & $0.29 a$ & $0.30 a$ & $0.46 a$ \\
\hline$P u-239$ & 1.0 & 0.25 & $1.7 a$ & 2.2 & 2.6 \\
\hline
\end{tabular}


Atmospheric Radloactivity Data, January 1970

\begin{tabular}{|c|c|c|c|c|c|}
\hline Latitude & $30-35^{\circ} \mathrm{N}$ & $9-10^{\circ} \mathrm{N}$ & $5-10^{\circ} \mathrm{N}$ & $5-10^{\circ} \mathrm{N}$ & $5-10^{\circ} \mathrm{N}$ \\
\hline Long itude & $103-106^{\circ} \mathrm{W}$ & $79^{\circ} \mathrm{W}$ & $79^{\circ} \mathrm{W}$ & $79^{\circ} \mathrm{W}$ & $79^{\circ} \mathrm{W}$ \\
\hline Date & 5 & 20 & 20 & 5 & 19 \\
\hline Altitude $(\mathrm{km})$ & 19.8 & 12.2 & 12.2 & 15.2 & 15.2 \\
\hline $\begin{array}{l}\text { Tropopause Ht. } \\
\text { (km) }\end{array}$ & $9.4-12.8$ & 16.2 & 16.2 & $15.5-15.8$ & 16.2 \\
\hline \multicolumn{6}{|l|}{ Isotopes } \\
\hline $\mathrm{Be}-7$ & 9940 & $<180$ & $<110$ & 620 & $170 c$ \\
\hline$M n-54$ & 35 & $<2$ & $<1$ & $<0.7$ & $<2$ \\
\hline $\mathrm{Fe}-55$ & $108 \mathrm{~b}$ & $<10$ & $-\infty$ & $<5$ & -- \\
\hline$S r-89$ & 6630 & $6.3 a$ & $8.9 a$ & $3.2 \mathrm{a}$ & $0.87 c$ \\
\hline Sr -90 & 181 & $0.75 b$ & 0.89 & $0.38 a$ & $<0.6$ \\
\hline$Z r-95$ & 11500 & 15 & 18 & $5.9 a$ & $3.4 \mathrm{a}$ \\
\hline $\mathrm{Cs}-137$ & 266 & $1.4 \mathrm{a}$ & $2.1 a$ & $0.54 a$ & $<1$ \\
\hline $\mathrm{Ba}-140$ & $4290 c$ & NR & $\mathbf{N R}$ & NR & NR \\
\hline $\mathrm{Ce}-141$ & -- & -- & $5.1 \mathrm{c}$ & -- & 820 \\
\hline $\mathrm{Ce}-144$ & 6650 & $2.7 a$ & 14 & $3.8 \mathrm{a}$ & $3.8 \mathrm{a}$ \\
\hline $\mathrm{Pb}-210$ & $0.35 b$ & $0.27 c$ & $<0.4$ & $0.23 b$ & $<0.9$ \\
\hline $\mathrm{Pu}-238$ & 0.31 & $<0.02$ & $0.02 b$ & $<0.01$ & $\mathbf{N R}$ \\
\hline Pu-239 & 1.9 & $0.01 c$ & $0.01 a$ & $<0.01$ & NR \\
\hline
\end{tabular}


Atmospheric Radioactivity Data, January 1970

\begin{tabular}{|c|c|c|c|c|c|}
\hline Latitude & $5-10^{\circ} \mathrm{N}$ & $5-6^{\circ} \mathrm{N}$ & $5-10^{\circ} \mathrm{N}$ & $5-10^{\circ} \mathrm{N}$ & $34-39^{\circ} \mathrm{S}$ \\
\hline Longitude & $79^{\circ} \mathrm{W}$ & $79^{\circ} \mathrm{W}$ & $79^{\circ} \mathrm{W}$ & $79^{\circ} \mathrm{W}$ & $68^{\circ} \mathrm{W}$ \\
\hline Date & 5 & 5 & 19 & 13 & 6 \\
\hline Altitude $(\mathrm{km})$ & 18.3 & 18.3 & 19.2 & 19.5 & 12.2 \\
\hline $\begin{array}{l}\text { Tropopause } \mathrm{Ht} \text {. } \\
(\mathrm{km})\end{array}$ & $15.5-15.8$ & $15.5-15.8$ & 16.2 & 15.8 & $10.7-11.6$ \\
\hline \multicolumn{6}{|l|}{ Isotopes } \\
\hline $\mathrm{Be}-7$ & $5810 a$ & 24400 & 1200 & $3820 a$ & 1070 \\
\hline$M n-54$ & $4.4 b$ & 14 & $2.6 a$ & $7.3 a$ & $<0.8$ \\
\hline $\mathrm{Fe}-55$ & -- & $<50$ & 13 & -- & $<5$ \\
\hline$S r-89$ & 1210 & 1830 & 143 & 1230 & $0.75 a$ \\
\hline Sr -90 & $55 a$ & 76 & 17 & $80 a$ & 1.1 \\
\hline$z r-95$ & 2320 & 3170 & 255 & 2250 & 4.8 \\
\hline Cs-137 & 88 & 120 & 28 & 119 & 1.8 \\
\hline $\mathrm{Ba}-140$ & NR & NR & $\mathbf{N R}$ & NR & NR \\
\hline $\mathrm{Ce}-141$ & 1310 & -- & -- & $<8$ & -- \\
\hline $\mathrm{Ce}-144$ & 1470 & 1880 & 295 & 1560 & 15 \\
\hline $\mathrm{Pb}-210$ & $<1$ & $1.6 \mathrm{~b}$ & $0.50 \mathrm{a}$ & $<1$ & $0.67 \mathrm{a}$ \\
\hline Pu-238 & $0.14 a$ & $0.26 b$ & $0.10 a$ & $0.20 \mathrm{a}$ & $0.01 \mathrm{~d}$ \\
\hline$P u-239$ & 0.53 & $0.82 a$ & 0.19 & 0.77 & $0.01 b$ \\
\hline
\end{tabular}




$$
\text { Atmospheric Radioactivity Data, January } 1970
$$

\begin{tabular}{|c|c|c|c|c|c|}
\hline Latitude & $40-45^{\circ} \mathrm{s}$ & $34-40^{\circ} \mathrm{s}$ & $40-45^{\circ} \mathrm{s}$ & $35-40^{\circ} \mathrm{s}$ & $40-45^{\circ} \mathrm{s}$ \\
\hline Long I tude & $67^{\circ} \mathrm{W}$ & $68^{\circ} \mathrm{W}$ & $67^{\circ} \mathrm{W}$ & $68^{\circ} \mathrm{W}$ & $67^{\circ} \mathrm{W}$ \\
\hline Date & 19 & 5 & 20 & 12 & 19 \\
\hline Altitude (km) & 12.2 & 15.2 & 15.2 & 18.3 & 18.3 \\
\hline $\begin{array}{l}\text { Tropopause Ht. } \\
(\mathrm{km})\end{array}$ & 15.8 & $10.7-11.7$ & 14.0 & $10.7-11.3$ & 15.8 \\
\hline \multicolumn{6}{|l|}{ Isotopes } \\
\hline $\mathrm{Be}-7$ & $1320 a$ & 14000 & 3190 & 2480 & 13500 \\
\hline $\mathrm{Mn}-54$ & $3.6 a$ & $6.0 \mathrm{~b}$ & $1.5 \mathrm{a}$ & $8.5 a$ & $7.1 a$ \\
\hline $\mathrm{Fe}-55$ & -- & -- & $<6$ & $39 a$ & -- \\
\hline Sr-89 & $1.4 \mathrm{~d}$ & 2700 & 8.3 & $17 \mathrm{~b}$ & 16 \\
\hline Sr-90 & 13 & $138 a$ & 7.9 & 80 & 63 \\
\hline $\mathrm{Zr}-95$ & 11 & 5360 & 18 & 49 & 67 \\
\hline Cs -137 & 19 & 218 & 13 & 67 & 92 \\
\hline $\mathrm{Ba}-140$ & $\mathbf{N R}$ & NR & NR & NR & NR \\
\hline $\mathrm{Ce}-141$ & $<2$ & 3230 & -- & -- & $28 d$ \\
\hline $\mathrm{Ce}-144$ & 138 & 3090 & 93 & 530 & 658 \\
\hline $\mathrm{Pb}-210$ & $<0.2$ & $<0.6$ & $0.77 a$ & $0.86 a$ & $<0.8$ \\
\hline $\mathrm{Pu}-238$ & $0.11 a$ & $0.47 a$ & $0.08 a$ & $0.35 a$ & $0.52 a$ \\
\hline $\mathrm{Pu}-239$ & 0.13 & 1.6 & $0.09 a$ & $0.46 a$ & 0.62 \\
\hline
\end{tabular}




\section{Atmospheric Radioactivity Data, January 1970}

\begin{tabular}{|c|c|c|}
\hline Latitude & $40-45^{\circ} \mathrm{S}$ & $40-45^{\circ} \mathrm{S}$ \\
\hline Longitude & $67^{\circ} \mathrm{W}$ & $67^{\circ} \mathrm{W}$ \\
\hline Date & 12 & 12 \\
\hline Altitude $(\mathrm{km})$ & 18.9 & 19.2 \\
\hline $\begin{array}{l}\text { Tropopause } H t \text {. } \\
(\mathrm{km})\end{array}$ & $10.7-11.3$ & $10.7-11.3$ \\
\hline \multicolumn{3}{|l|}{ Isotopes } \\
\hline $\mathrm{Be}-7$ & $7440 a$ & 8380 \\
\hline$M n-54$ & $9.3 a$ & $15 a$ \\
\hline $\mathrm{Fe}-55$ & -- & $48 a$ \\
\hline Sr -89 & $10 c$ & $17 \mathrm{~b}$ \\
\hline Sr -90 & 72 & 78 \\
\hline $\mathrm{Zr}-95$ & 63 & 72 \\
\hline Cs -137 & 101 & 111 \\
\hline $\mathrm{Ba}-140$ & NR & NR \\
\hline $\mathrm{Ce}-141$ & $31 d$ & -- \\
\hline $\mathrm{Ce}-144$ & 758 & 889 \\
\hline $\mathrm{Pb}-210$ & $<4$ & $0.50 \mathrm{~b}$ \\
\hline $\mathrm{Pu}-238$ & $0.62 a$ & $0.68 a$ \\
\hline $\mathrm{Pu}-239$ & $0.64 a$ & 0.81 \\
\hline
\end{tabular}




\section{PART IV}

RECENT PUBLICATIONS RELATED TO RADIONUCLIDE STUDIES 
Recent Publications Related to Radionuclide Studies

Beasley, T.M. and E. E. Held

Silver-108m in Biota and Sediments at Bikini and Eniwetok Atolls

Nature, 230, pp 450-451, (1971)

Beck, J. N., et al

Radioactive Cerium Fallout

Health Physics, 21, No. 3, Sept. 1971

Beninson, D., et al

Fallout Radioactivo Debido A Las Explosiones En El Pacifico

Sur En El Periodo 1966-1970

Argentine Atomic Energy Commission

RS $28 / 49$

Buenos Aires 1971

Bernhardt, D. E., et al

Protective Actions for Radioiodine in Milk

Health Physics, 21, No. 3, Sept. 1971

Blamont, J.E., et al

An Experimental Demonstration of the Isentropic Nature of the Motion of Stratospheric Air Masses

$\mathrm{J}$, of the Atmospheric Science, 28, pp 1015-20 (1971)

Blanchard, R. L. and Moore, J.B.

Body Burden Distribution and Internal Dose of $210_{\mathrm{Pb}} 210_{\mathrm{Po}}$

in $U$ Miner Population

Health Physics 21, No. 4, September 1971

Bomex Bulletin No. 10, June 1971

National Oceanic \& Atmospheric Administration

Rockville, Md. 20852

Boulenger, $\mathrm{R}$. and $\mathrm{X}$. deMaere

La Retombee Radio-Active Mesuree a Mol

R.2505, 144, Ave. E. Plasky, Bruxelles 4, Belgium

Carlberg, J.R., et al

Total Dust, Coal, Free Silica, and Trace Metal Concentrations

in Bituminous Coal Miners' Lungs

American Indus. Hygiene Assoc. J. 32, No. 7, July 1971 
Chen, T.S., et al

Daily Fluctuations of Radioactive Fallout Particles in Ground-level Air

Tellus, 1970

Chertok, R. J. and S. Lake

Biological Availability of Radionuclides Produced by the

Plowshare Event Schooner-III. Accumulation, Excretion

Rates and Body Distribution in Peccaries after Daily

Ingestion of Debris

Health Physics, 20, No. 6, June 1971

Chorvat, D. and Trnovec, T.

Quantification of Biological Effects of Uncontrolled Release

of Radioactive Substances into the Environment and Resulting Measures

Cesk Hyg. $16(1): 29-34$, Feb. 1971

Clarkson, L. S.

On the Performance of Various Types of Rain-gauge in the Field

Meteorological Magazine, 100, No. 1189, Aug. 1971

Daley, J.C. and Gabay, J.J.

Rapid Screening of Environmental Samples using Gamma Spectrometry Health Physics, 20, No. 6, June 1971

DeBoeck, R., et al

The Determination of 210 Po in Urine

Hea1th Physics, 20, No. 4, April 1971

Dolphin, G. W.

The Biological Problems in the Radiological Protection of

Workers Exposed to 239-Pu

Health Physics, 20, No. 6, June 1971

Drew, R, T.

$212 \mathrm{~Pb}$ Distribution studies in the Rat

Health Physics, 20, No. 6, June 1971

Drichko. P.

Age - Specific Peculiarities of ${ }^{137} \mathrm{Cs}$ Elimination from the Human Organism

Med. Radio1., 16, No. 6, June 1971 
Dyson, F. J。

Energy in the Universe

Scientific American, 225, No. 3, September 1971

Engelmann, R. J.

Scavenging Prediction Using Ratios of Concentrations in

Air and Precipitation

Appl. Meteorology, 10, pp 493-97, 1971

Esman, N。A. and M. Corn

Residence Time of Particles in Urban Air

Atmospheric Environment, 5, No. 8, Aug. 1971

Ettenhuber, E.

Accumulation of Radionuclides in Fishes

Isotopenpraxis 7 (3) March 1971

Final Report of Research Project on Plutonium Hazards 1966 April - 1970 March

National Institute of Radiological Sciences

Anagawa, Chiba-Shi, Japan

Gates, D.

The Flow of Energy in the Biosphere

Scientific American, 225, No. 3, September 1971

Glomski, C.A. and H. Brody

Distribution and Concentration of Mercury in Autopsy

Specimens of Human Brain

Nature, 232, No。5307, July 16, 1971

Gregory, J.B. and D.T. Rees

Wind Profiles to $100 \mathrm{~km}$ near $53 \mathrm{~N}$ during 1969

J. of Atmospheric Sciences, 28(6) pp 1079-1082 (1971)

Grueter, $\mathrm{H}$.

Radioactive Fission Product $137 \mathrm{Cs}$ in Mushrooms in

W. Germany during 1963-70

Health Physics, 20, No. 6, June 1971

Gudiksen, P. H.

Semiannual Report of Environmental Levels of Radioactivity

in the Vicinity of the Lawrence Livermore Lab January thru June 1971

UCRL 51093, JulY 12, 1971 
dedalia, D.

Physique De L'Atmosphere

C.R. Acad.Sc。 Paris, t. 273, p. 57-60

(5 Juillet 1971)

Hansen, W.R., et al

$210 \mathrm{POO}_{2}$ Movement in a Mountain Watershed Soil

Health Physics, 20, No. 4, April 1971

Hanson, W.C.

137Cs: Seasonal Patterns in Native Residents of Three Contrasting Alaskan Villages

Health Physics, 20, No, 6, June 1971

Harrison, $P_{0} R_{0}$, et al

Time Variations of Lead, Copper and Cadmium Concentrations in

Aerosols in Ann Arbor, Michigan

A.tmospheric Environment, 5 , No. 8, August 1971

Hopkins, J.H. and Baxter, R.C.

Maternal Age and $90 \mathrm{Sr}$ Retention in Rat offspring

Health Physics, 20, No. 6, June 1971

Hudson River Ecology

A symposium

October 1969 - at the Sterling Forest Conference Center

Sterling Forest, Tuxedo, N, Y。

Inou, Y. and Sakanoue, M.

The Determination of Plutonium in the Fall-out Samples at

Kanazawa

The Science Reports of Kanazawa University, XV, No, 1, June 1970

Ishimori, T. and $\mathrm{E}$ 。Akatsu

Preparation of $236 \mathrm{Pu}$

$\mathrm{J}$. of Nuclear Science \& Technology, 6 (8) p. 480-82, Aug. 1969

Jaworowski, Z., et al

$226_{\mathrm{Ra}}$ in Contemporary and Fossil snow

Health Physics, 20, No. 4, April 1971 
Joshi, L.U,, et al

Investigations on $210 \mathrm{~Pb}$ Concentrations in Various Regions of India

Health Physics, 20, No. 6, June 1971

Junge, C. and Scheich, G.

Determination of the Acid Content of Aerosol Particles

Atmospheric Environment, 5, (1971)

Kirchmann, R. and E. Cantillon

Observed and Predicted $90 \mathrm{Sr}$ and ${ }^{137} \mathrm{Cs}$ Levels in Milk

Nature, 230, No. 5296, April 30, 1971

Kolarova, H, and Santroch, J.

Atmospheric Radioactivity in Czechoslovakia in 1968-69

Meteoro1. Zpr (Praha) 23(5), Oct. 31, 1970

Komhyr, W.D., et al

Atmospheric Total Ozone Increases during the $1960 \mathrm{~s}$

Nature, 232, p. 390-91 (1971)

Kostial, D., et al

Lead Absorption from the Intestine in Newborn Rats

Nature, 223, No.5321, October 22, 1971

Liniecki, $\mathrm{T}$.

Kinetics of Calcium, strontium, Barium, and Radium in Rats Health Physics, 21, No. 3, September 1971

Langford, J.C.

Particulate $\mathrm{Pb}, \mathrm{Pb}-210$, and $\mathrm{Po}-210$ in the Environment

Health Physics, 20, No. 4, April 1971

Law, S. L。

Methyl Mercury and Inorganic Mercury collection by a

Selective Chelating Resin

Science, 174, No. 4006, Oct. 15, 1971

Li, $Y_{0} H$.

The Solubility of $\mathrm{CO}_{2}$ in Water and Sea Water

J. of Geophysical Research - Oceans and Atmospheres

Vol. 76, No. 18, June 20, 1971 
tiss, P. S.

Exchange of $\mathrm{SO}_{2}$ between the Atmospheric and Natural Waters Nature, 233, pp 327-29 (1971)

Luna, R.E., et al

Variability of Air Sampler Data

Atmospheric Environment, ㅁ. No. 8, August 1971

MCEIroy, M.B. and J.C. McConnell

Nitrous Oxide: A Natural Source of Stratospheric NO

J. of the Atmospheric Sciences, 28, pp. 1095-98, 1971

Mamuro, T.

Annual Report of the Radiation Center of Osaka Prefecture

Volume 11, 1970

Radiation Center of Osaka Prefecture

Shinke-Cho, Sakai, Osaka, Japan

Martinez, J., et al

Spanish Moss, A Sensor for Lead

Nature, 233, No.5321, October 22, 1971

A Mathematical Analysis of the Effects of Wind on Redistribution of Surface Contamination

WASH-1187, UC-53, September 1971

Nydal, R., et al

Bomb $\mathrm{C}^{14}$ in the Human Population

Nature, 232, pp. 418-21 (1971)

Oniou, Y. and M. Sakanoue

The Determination of Plutonium in Soil Samples

$\mathrm{J}$ 。 of Radiation Research 11-2 (July 1970)

Overcamp, T.J. and Hoult, D.P.

Precipitation in the wake of cooling Towers

Atmospheric Environment, ㅁ, No. 9, Sept 1971

Persson, G. and Sisefsky, J.

Radioactive Particles from the 8th Chinese Nuclear Test Health Physics, 21, No. 3, September 1971 
Persion, B.R.

${ }^{90} \mathrm{Sr}$ in Northern Sweden: Relationships and Annual Variations from 1961 to 1969 in Lichen, Reindeer and Man

Health Physics, 20, No. 4, April 1971

Petering, H. G., et al

Trace Metal Content of Hair

Arch. Environmental Health, 23, September 1971

Pierce, J.O., and J. H. Meyer

Sampling and Analysis Considerations in Evaluating Levels of Atmospheric $\mathrm{Pb}$

Atmospheric Environment, 5, No. 9, September 1971

Porsch, W.M., et al

Use of Astronomical Telescopes to Measure Aerosol Pollution

Nature, 233, pp 326-327, (1971)

Prokhorov, V.M., et al

Effect of Liming of Soil on the Diffusion Rate of ${ }^{90} \mathrm{Sr}$ Agrokhimiya, 7, No. 2, 40-8(1970) in Russian

Radioactive Contamination of Foodstuffs in the Countries

of the Community in 1969

EUR $4667 \mathrm{~d} / \mathrm{f} / \mathrm{i} / \mathrm{n}$

Commission of the European Communities

Directorate General Social Affairs

Directorate for Health and Safety - Luxembourg

Luxembourg, July 1971

Rapport D'Activite

Juin, Juillet and Aout, 1971

SCPRI B.P. $\mathrm{n}^{\circ} 35,78$ LeVesinet, France

Annexe Au Rapport Mensuel

Detail Des Resultats De Mesure

Juin, Juillet and Aout, 1971

SCPRI B.P. $\mathrm{n}^{\circ} 35,78$ LeVesinet, France

Radioactivity Survey Data in Japan

NIRS-RSD-30, February 1971

National Institute of Radiological Sciences, Chiba, Japan 
Radioactivite Ambiante Dans Les Pays De La Communaute Bulletin Trimestriel, $\mathrm{N}^{\circ}$ 4/70, Avril and Juillet, 1971

Rains, D. W.

Lead Accumulation by Wild Oats (avena fatua) in a Contaminated Area

Nature, 233, pp 210-211 (1971)

Retombees Radioactives a la Suite des Tirs Nucleaires en Polynesie

Mai - Decembre 1970, Republique Francaise

Schaefer, H。 J.

Radiation Exposure in Air Travel

Science, 173, No. 3999, August 27, 1971

Schmitt, No, et al

Lead Poisoning in Horses

Arch. Environmental Health, 23, September 1971

Schroeder, H. A.

Metals in the Air

Environment, 13, No. 8, pp 18-31, October 1971

Singer, S.F.

Stratospheric Water Vapour Increase due to Human Activities Nature, 223, No. 5321, October 22, 1971

Sisefsky, J. and Persson, G.

Debris over Sweden from the Chinese Nuclear Weapons Test September 1969

Health Physics, 21, No. 3, September 1971

Smith, J.D, et al

Mercury in water of the Tidal Thames

Nature, 232, No. 5310, August 6, 1971

Srinivasan, B., et al

Iodine-129 in Terrestrial Ores

Science, 173, No. 3994, pp 327-328, July 23, 1971 
Stigall, G.E., et al

131I Discharges from an Operating Boiling water Reactor Nuclear Power Station

Health Physics, 20, No. 6, June 1971

Studies on the Radioactive Contamination of the Sea Annual Report 1970

EUR 470le, 1971

Study of Rainout of Radioactivity in Illinois

10th Progress Report, COO-1199-20, Nov. 1971

Illinois State Water Survey at the Univ. of Illinois

Urbana, Illinois

Surveillance De La Radioactivite De L'Atmosphere et Des Eaux Commissariat A I'Energie Atomique

1er Trimestre 1971, France

Surveillance De La Radioactivite De La Chaine Alimentaire (Comite Technique Interministeriel pour les questions

relatives a l'application du traite instituant la communaute Europeenne de L'Energie Atomique

ler Trimestre 1971, FRANCE

Surveillance De La Radioactivite De L'Atmosphere Et Des Eaux 4eme Trimestre 1970, FRANCE

Surveillance De La Radioactive De La Chaine Alimentaire 4eme Trimestre 1970, FRANCE

Sutton, A., et al

Excretion and Retention of Stable Strontium in Children Nature, 230, No. 5293, April 9, 1971

Szalay, A. and Csongor, E.

Fission Products in the Atmospheric Precipitation in

Debrecen, Hungary, During 1968 and 1969

Acta Phys. Acad. Sci. Hung. 29, No. 4, pp 407-13 (1970) 
Takahashi, H. and Hirayama, K.

Accelerated Elimination of Methyl Mercury from Animals Nature, 232, No. 5307, July 16, 1971

1971 Annual Report, UCD 472-118

Radiobiology Laboratory, School of Veterinary Medicine University of California, Davis

Umweltradioaktivitat und Strahlenbelastung Jahresbericht 1970

Schriftenreihe Kernforschung, 4 (in German)

Der Bundesminister, Fur Bildung und Wissenschaft

West Germany, Juni 1971

Urakubo, G., et al

Sr 90 and Cs 137 Concentrations in Imported Foods (in Japan)

Bull. Nat. Institut Hyg. Sci. (Tokyo) 87: 84-6, Dec. 1969

Van Dongen, $\mathrm{R}_{0}$, et al

Gross Radioactivity in Airborne Dust

(Results of measurements during 1967)

Report RA-42, Radiation Research Lab, Bilthoven, Apr。 1968

Van der Borght, 0 .

Intestinal Absorption \& Body Retention of 226-Radium and

47-Calcium in Mice: Effect of Sodium Alginate, Measured in vivo with a $\mathrm{Ge}(\mathrm{Li})$ Detector

Health Physics, 21. August 1971

Vives, M.V.

Polonium-210 Urinalysis as an Index of Radium and or Radon Exposure

Philipp. Nucl. J., 2:170-3, 1969 